In cooperation with the

New Hampshire Department of Environmental Services,

Waste Management Division

\title{
Geology and Preliminary Hydrogeologic Characterization of the Cell-House Site, Berlin, New Hampshire, 2003-04
}

Scientific Investigations Report $2004-5282$

U.S. Department of the Interior

U.S. Geological Súfycy 
Cover--Photograph shows the cell-house site to the left, the bedrock bank of the Androscoggin River in the middle, and Mt. Madison and Adams and the Berlin Pulp Mill in the background. 


\section{Geology and Preliminary Hydrogeologic Characterization of the Cell-House Site, Berlin, New Hampshire, 2003-04}

By James R. Degnan, Stewart F. Clark, Jr., Philip T. Harte, and Thomas J. Mack

In cooperation with the

New Hampshire Department of Environmental Services,

Waste Management Division

Scientific Investigations Report 2004-5282 


\section{U.S. Department of the Interior \\ Gale A. Norton, Secretary \\ U.S. Geological Survey \\ Charles G. Groat, Director}

U.S. Geological Survey, Reston, Virginia: 2005

For sale by U.S. Geological Survey, Information Services
Box 25286, Denver Federal Center
Denver, CO 80225
For more information about the USGS and its products:
Telephone: 1-888-ASK-USGS
World Wide Web: http://www.usgs.gov/

Any use of trade, product, or firm names in this publication is for descriptive purposes only and does not imply endorsement by the U.S. Government.

Although this report is in the public domain, permission must be secured from the individual copyright owners to reproduce any copyrighted materials contained within this report. 


\section{Contents}

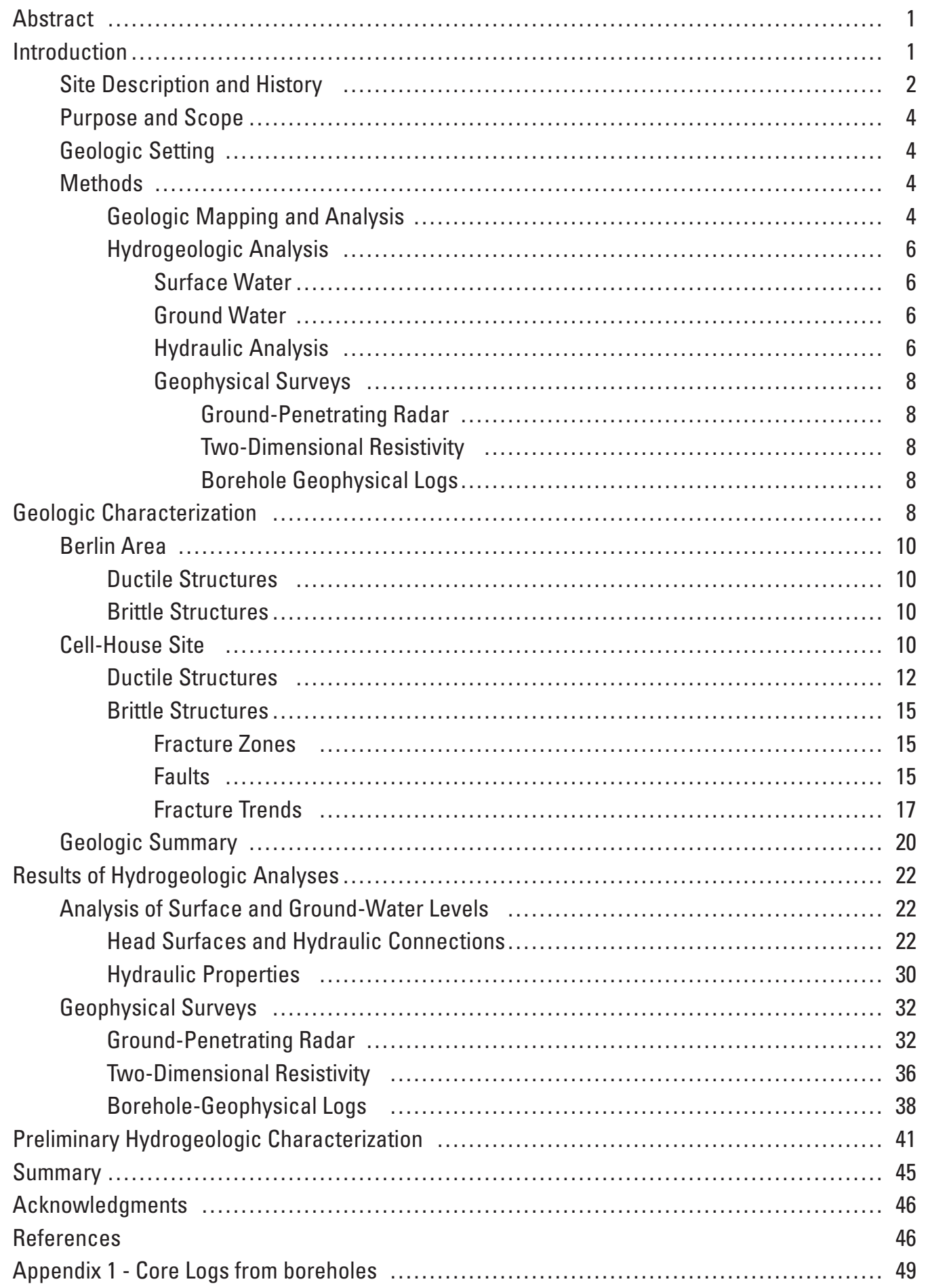




\section{Plate}

1. Geologic map of exposed bedrock at the cell-house site, Berlin, N.H.

\section{Figures}

1-2. Maps Showing -

1. Location of the study area, Berlin, N.H., with lineaments from high-altitude photography.

2. Location of reference grid, geophysical survey lines, mapped bedrock area, and water-level monitoring points at the cell-house site, Berlin, N.H...................... 3

3. Schematic diagram showing lower hemisphere stereonet projections

4. Map showing bedrock geology, azimuth-frequency plots of fractures, fracture domains,

and foliation near the cell-house site, Berlin, N.H.

5-7. Photographs Showing -

5. Fine-grained gneiss showing three sets of planar, parallel fractures from grid cell B21 (plate 1), view to southwest, at cell-house site, Berlin, N.H.

6. Trend of gneissosity in coarse-grained gneiss cut by pegmatite from grid cell B24 (plate 1), cell-house site, Berlin, N.H.

7. Vugs along the margin of chlorite-schist layer on a vertical outcrop face from grid cell B25 (plate 1), cell-house site, Berlin, N.H.

8. Stereonet plots showing ductile structures in the bedrock outcrop at the cell-house site, Berlin, N.H.

9. Photograph showing fold hinge in asymmetric F2 fold in chlorite-schist layer, cross section view to northeast, in grid cell B25 (plate 1), cell-house site, Berlin, N.H. . . 14

10. Stereonets and azimuth-frequency plots showing orientations of planar structures in the bedrock outcrop at the cell-house site, Berlin, N.H.

11-14.Photographs Showing-

11. Outcrop with en échelon fractures in an en échelon fracture zone, cell-house site, Berlin, N.H.

12. Outcrop of silicified fracture zone (boundary shown by red dashed line) and nonplanar irregular fractures and gneiss, cell-house site, Berlin, N.H.

13. Outcrop with multiply sheared quartz containing interleaved chlorite schist, cell-house site, Berlin, N.H.

14. Outcrop with fault-bounded silicified pegmatite, cell-house site, Berlin, N.H. ...... 18

15. Cell-by-cell analysis showing principal fracture trends at the cell-house site,

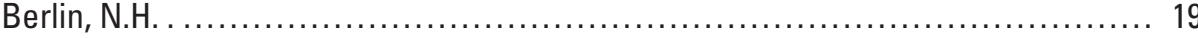

16. Diagrams showing orientation of all fractures at the cell-house site, Berlin, N.H. ....... 20

17. Stereonet plots showing fracture-intersection lineations for the northern, north-central, and south-central regions of the riverbank at the cell-house site, Berlin, N.H.

18. Generalized cross section showing the bedrock geology at the cell-house site outcrop from grid 0 to 36 , (360 feet) looking east, Berlin, N.H. 
19-20. Maps Showing-

19. Hydraulic-potentiometric-head surface of (A) low (March 20, 2003) and (B) high (April 2, 2003) water-level conditions in overburden at the cell-house site, Berlin, N.H.

20. Hydraulic-potentiometric-head surface of $(A)$ low (March 20, 2003) and

(B) high (April 2, 2003) water-level conditions in bedrock at the cell-house site,

Berlin, N.H.

21-26. Graphs Showing-

21. Daily precipitation and average daily water levels from overburden wells MW-2, MW-4, MW-5, P-21, and canal stage at the cell-house site, Berlin, N.H.... 26

22. Average daily water levels from bedrock wells MW-7, MW-8, and MW-9 and river stage from surface-water measuring point SW-1 at the cell-house site, Berlin, N.H.

23. Average daily water levels and specific conductance at well MW-7 at the cell-house site, Berlin, N.H. 30

24. Average daily stage at SW-1 and specific conductance in the Androscoggin River at the cell-house site, Berlin, N.H.... 31

25. Five-minute-interval water level and specific conductance from bedrock well MW-7 and river stage SW-1 at the cell-house site, Berlin, N.H.

26. Observed water levels and computed water levels for the assigned horizontal hydraulic conductivity $(\mathrm{HK})$ in response to river stage changes for bedrock wells (A) MW-7, (B) MW-8, and (C) MW-9 on April 3, 2003, cell-house site, Berlin, N.H.

27-32. Cross Sections Showing -

27. Ground-penetrating-radar profiles and interpretations from lines 1,3, and 2 on the bank of the Androscoggin River, cell-house site, Berlin, N.H.

28. Ground-penetrating radar profiles from line 26 on the capped area of the cell-house site, Berlin, N.H. 36

29. Resistivity profiles from lines 1 and 2 on the bank of the Androscoggin River, cell-house site, Berlin, N.H.

30. Resistivity profiles showing dipole-dipole array from lines 8 and 9 on the southwestern perimeter of the cell-house site, Berlin, N.H.

31. Resistivity profiles showing dipole-dipole array from lines 10,11 , and 12 on the southern perimeter of the cell-house site, Berlin, N.H.

32. Resistivity profiles showing dipole-dipole array from lines 13 through 18 on the eastern perimeter of the cell-house site, Berlin, N.H.

33-34. Graphs Showing-

33. Borehole-geophysical logs of well MW-14, cell-house site, Berlin, N.H 41

34. Borehole-geophysical logs of well MW-15, cell-house site, Berlin, N.H. 42

35. Lower hemisphere stereonets showing orientation with poles to plane of bedrock structure in wells (A) MW-14 and (B) MW-15, cell-house site, Berlin, N.H. .... 43

36. Conceptual model showing the hydrogeology at the cell-house site, Berlin, N.H. 


\section{Tables}

1. Construction information for selected wells and stage monitoring sites, cell-house site, Berlin, N.H.

2. Altitudes and differences of heads in overburden and bedrock well pairs at the cell-house site, Berlin, N.H..

3. Statistical summary and ranking of manually measured water levels, 2003, cell-house site, Berlin, N.H.

4. Summary of continuous surface- and ground-water monitoring sites and water levels, water year 2003, cell-house site, Berlin, N.H.

5. Summary of connectivity and estimates of bulk hydraulic conductivity between bedrock wells and the Androscoggin River, cell-house site, Berlin, N.H.

\section{Conversion Factors}

\begin{tabular}{|c|c|c|}
\hline Multiply & By & To obtain \\
\hline \multicolumn{3}{|c|}{ Length } \\
\hline inch (in.) & 2.54 & centimeter $(\mathrm{cm})$ \\
\hline inch (in.) & 25.4 & millimeter (mm) \\
\hline foot $(\mathrm{ft})$ & 0.3048 & $\operatorname{meter}(\mathrm{m})$ \\
\hline mile (mi) & 1.609 & kilometer $(\mathrm{km})$ \\
\hline \multicolumn{3}{|c|}{ Flow rate } \\
\hline foot per day (ft/d) & 0.3048 & meter per day $(\mathrm{m} / \mathrm{d})$ \\
\hline gallon per minute (gal/min) & 0.06309 & liter per second $(\mathrm{L} / \mathrm{s})$ \\
\hline \multicolumn{3}{|c|}{ Mass } \\
\hline pound, avoirdupois (lb) & 0.4536 & kilogram $(\mathrm{kg})$ \\
\hline \multicolumn{3}{|c|}{ Hydraulic conductivity } \\
\hline foot per day (ft/d) & 0.3048 & meter per day $(\mathrm{m} / \mathrm{d})$ \\
\hline \multicolumn{3}{|c|}{ Hydraulic gradient } \\
\hline foot per mile (ft/mi) & 0.1894 & meter per kilometer $(\mathrm{m} / \mathrm{km})$ \\
\hline
\end{tabular}

Temperature in degrees Celsius $\left({ }^{\circ} \mathrm{C}\right)$ may be converted to degrees Fahrenheit $\left({ }^{\circ} \mathrm{F}\right)$ as follows:

$$
{ }^{\circ} \mathrm{F}=\left(1.8 \times{ }^{\circ} \mathrm{C}\right)+32
$$

Horizontal coordinate information is referenced to the "North American Datum of 1983 (NAD 83)."

Vertical coordinate information (Altitude), as used in this report, refers to distance above the vertical datum using a survey datum of Tighe and Bond (2001) and can be converted to "North American Vertical Datum of 1988 (NAVD 83)," by subtracting $4.73 \mathrm{ft}$.

Specific conductance is given in microsiemens per centimeter at 25 degrees Celsius $\left(\mu \mathrm{S} / \mathrm{cm}\right.$ at $\left.25^{\circ} \mathrm{C}\right)$.

Resistivity is measured in ohm feet (ohm-ft). 


\title{
Geology and Preliminary Hydrogeologic Characterization of the Cell-House Site, Berlin, New Hampshire, 2003-04
}

\author{
By James R. Degnan, Stewart F. Clark, Jr., Philip T. Harte, and Thomas J. Mack
}

\section{Abstract}

Elemental mercury is present in depressions and fractures on the exposed bedrock surface, in the overburden, and dissolved in ground water at the site of a former chlor-alkali plant (termed the cell-house site) along the east bank of the Androscoggin River, in Berlin, N.H. An overburden barrier wall is upgradient of the site, and an impermeable cap covers the site where plant buildings once stood. During 2002-03, geologic mapping, geophysical, and hydrogeologic data were collected to develop a preliminary characterization and conceptual model of the ground-water-flow system to assist with the ongoing site investigation and remediation efforts.

At the cell-house site, thin, generally less than 20-foot thick overburden, consisting of till and demolition materials, overlies fractured crystalline bedrock. Bedrock at the site consists of gneiss with thin discontinuous lenses of chlorite schist and discontinuous tabular pegmatite. Two distinct fracture domains, with principal trends to the west and northwest, and to the north, overlap near the site. The cell-house site shows principal trends common to both domains.

Gneiss is the most abundant rock at the site. Steeply dipping fractures within the gneiss terminate on subhorizontal contacts with pegmatite and on moderately dipping contacts with chlorite schist. Steeply northwest-dipping en échelon fracture zones, parallel joint zones, and silicified brittle faults show consistent strikes to the northeast. Gently east-dipping to subhorizontal fractures, sub-parallel to gneissosity, strike northeast.

The impermeable cap, barrier wall, and bedrock surface topography affect ground-water flow in the overburden. There is relatively little ground-water flow in the overburden in the capped area and a poor hydraulic connection between the overburden and the underlying bedrock over most of the site. The overburden beneath the cap may receive inflow through or beneath the barrier wall, or by flow through vertical fractures in the underlying bedrock beneath the barrier wall.

The bedrock aquifer near the river is well connected to the river and head difference in the bedrock across the site are large (greater than $13 \mathrm{ft}$ ). Horizontal hydraulic conductivities of 0.2 to $20 \mathrm{ft} / \mathrm{d}$ were estimated for the bedrock. Individual fractures or fracture zones likely have hydraulic conductivities greater than the bulk rock. Subhorizontal fractures occur at pegmatite contacts or along chlorite schist lenses and may serve as ground-water conduits to the steeply dipping fractures in gneiss. The effective hydraulic conductivity across the site is likely to be in the low range of the estimated values $(0.2 \mathrm{ft} / \mathrm{d})$. Ground water discharges to the river from the bedrock aquifer and is greatest during periods of large river stage fluctuations.

\section{Introduction}

The cell-house site in Berlin, N.H., was part of a chloralkali plant associated with a pulp and paper mill on the bank of the Androscoggin River (fig. 1). The chlor-alkali plant used elemental (liquid) mercury in the papermaking process. Mercury was released and seeped into the overburden and underlying fractured bedrock as a result of this process and represents a risk to human health and the environment. The extent of mercury contamination in the bedrock and mechanisms of transport to the riverbank are unknown.

The cell-house site is primarily a fractured rock setting where there was little information about the geology and hydrogeology prior to this study. Ground-water flow in fractured crystalline bedrock is one of the least well understood areas of investigation in hydrogeology and is a priority research interest of the U.S. Geological Survey (USGS). Characterization was needed to provide geologic information and a conceptual understanding of hydrogeology of the site. The results of this investigation add to the understanding of the fractured bedrock at the site for future remedial activities and provided information needed to guide ongoing investigations. The USGS conducted this study, in cooperation with the New Hampshire Department of Environmental Services (NHDES), Waste Management Division, from October 2002 through February 2004. Geologic mapping, water-level monitoring, and geophysical surveys were integrated to characterize fractured bedrock at the study site (fig. 1). 


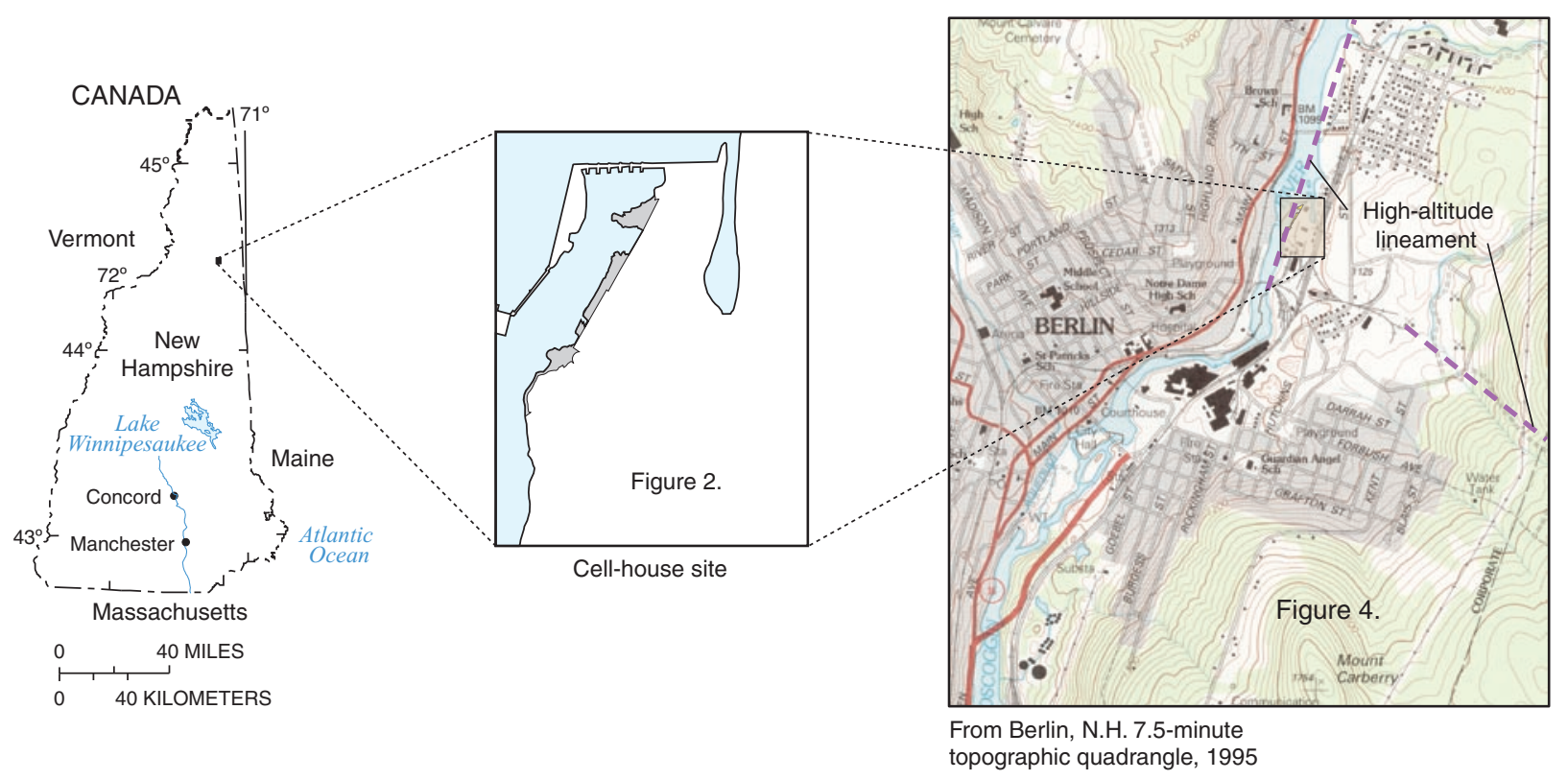

Figure 1. Location of the study area, Berlin, N.H., with lineaments from high-altitude photography. (Lineaments from Ferguson and others, 1999).

\section{Site Description and History}

The history of the site has been provided by Margaret Bastien of the New Hampshire Department of Environmental Services (New Hampshire Department of Environmental Services, written commun., 2004). The chlor-alkali plant operated from the late 1890s though the 1950s on the eastern bank of the Androscoggin River (fig. 2), north and west of the Berlin Paper Mill. The Androscoggin River defines the western site boundary and the Saw Mill Dam is located immediately to the north of the site (fig. 2). Sodium hydroxide and chlorine were manufactured from a brine solution using either diaphragm or mercury cells located in several buildings on site. Both types of cells use an electrochemical process and specifically, a mercury cell used a mercury cathode (a thin layer of elemental (liquid) mercury) and commonly a graphite anode. In general, a brine solution ( 25 percent sodium chloride by weight) is passed through the cell and chlorine gas is produced at the anode and sodium amalgam at the cathode. Sodium hydroxide and hydrogen are recovered in a decomposer from the sodium mercury amalgam and elemental mercury is recycled back into the electrochemical cell after recovery. Sources of mercury waste from the process include the brine purge, cell wash water, brine mud from brine purification, spent graphite from decomposer cells, spent caustic filtration cartridges, and spilled elemental mercury. Mercury loss from this process has been estimated to be $0.5 \mathrm{lbs}$ of mercury lost for every ton of chlorine produced. The amount of chlorine produced during the plant's operation is unknown.

In the 1990s, elemental mercury was observed in bedrock fractures along the riverbank and in river sediment. Mercury and lead, exceeding State regulations, were identified in soil and ground water at overburden and bedrock borings and wells installed at the site (Tighe and Bond, Inc., 2001). Efforts to contain mercury at the site, and eliminate seepage to the river, included demolition of the cell houses, installation of a synthetic cap over the site, to prevent infiltration of precipitation, installation of a bentonite-soil slurry (barrier) wall on the site perimeter, and pressure grouting the bedrock along the riverbank. The intent of these remedial actions was to eliminate ground-water flow through the site's overburden and reduce the driving force for contaminant migration.

Since the late 1990s, approximately 135 lbs of mercury were removed from sediment in the river and riverbank at the site (Margaret A. Bastien, New Hampshire Department of Environmental Services, written commun., 2003). Despite containment and yearly removal efforts, elemental mercury continues to appear in depressions at bedrock fractures along the riverbank at the cell-house site. Mercury at the cell-house site is in the following three phases: (1) dissolved in ground water (2) liquid (elemental mercury), and (3) solid amalgam where it has combined with other metals. 


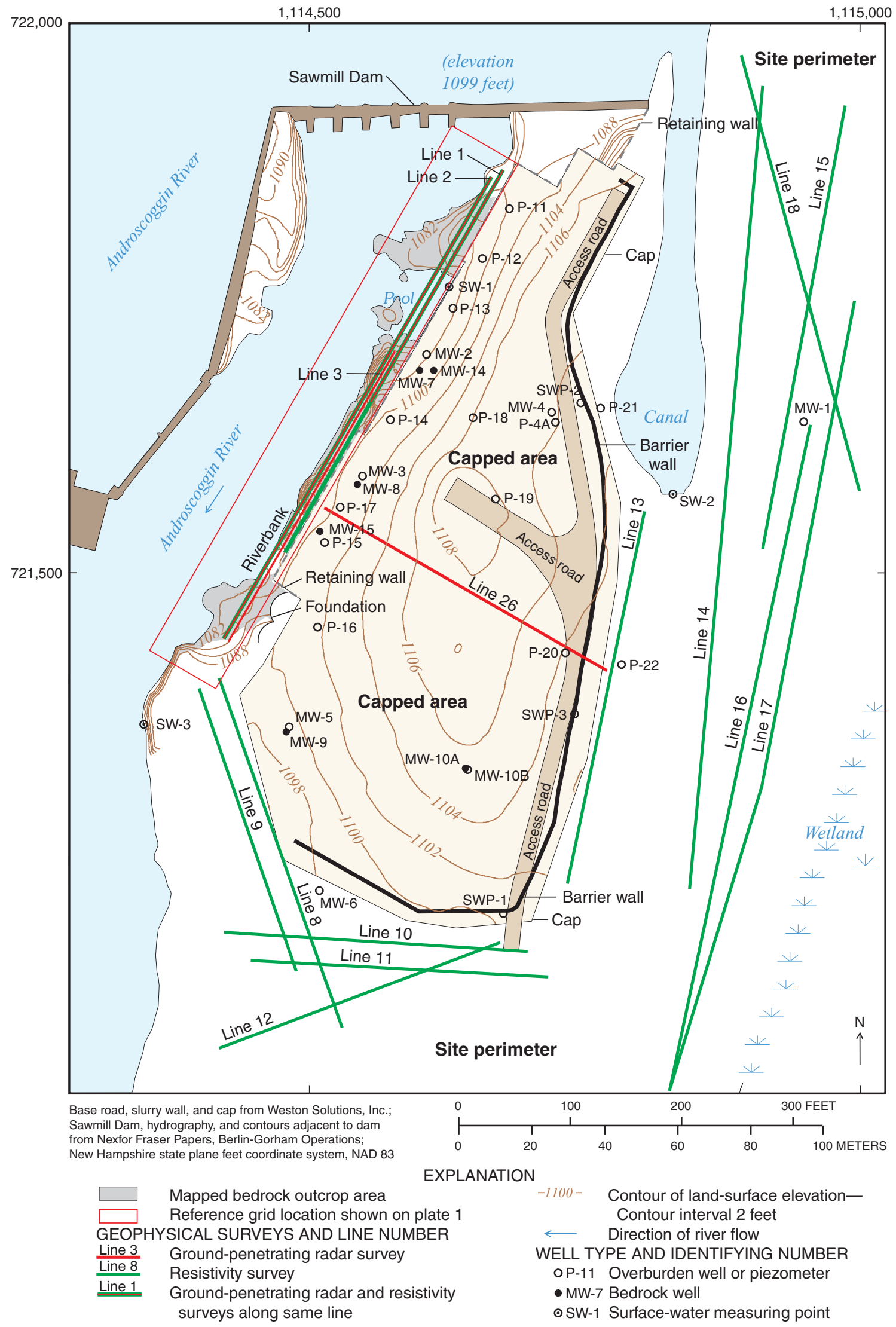

Figure 2. Location of reference grid, geophysical survey lines, mapped bedrock area, and water-level monitoring points at the cell-house site, Berlin, N.H. 
Geology and Preliminary Hydrogeologic Characterization of the Cell-House Site, Berlin, New Hampshire, 2003-04

\section{Purpose and Scope}

The purpose of this report is to present the results of geologic mapping, water-level analyses, and geophysical surveys to characterize the bedrock and to determine the location and orientation of potentially transmissive zones in the rock at the cell-house site in Berlin, N.H. The results of this investigation add to the understanding of the fractured bedrock at the site for remedial activities and provide information needed for ongoing site investigations. Geologic mapping was conducted at the riverbank and selected locations in the Berlin area, and geophysical surveys were used to collect data at the riverbank, site perimeter, and on the site cap. Borehole-geophysical logs were collected at two wells to examine bedrock-fracture characteristics beneath the site cap adjacent to the river. Continuous water-level monitoring was conducted at eight wells and in the river to examine the hydraulic connection between the wells and the river. Because of the scope of the investigation, the characterization focuses on the bedrock geology of the cell-house site and does not include detailed analysis of the overburden materials.

\section{Geologic Setting}

Berlin, N.H., is on the eastern edge of the Bronson Hill anticlinorium, and more specifically, on the southeast flank of the Jefferson Dome (Billings and Billings, 1975). Billings and Billings (1975) describe three stages of rock deformation and associated development of foliation in the region. The Androscoggin River channel and narrow valley in Berlin is underlain by metamorphosed biotite-quartz monzonite of the Ordovician Oliverian Plutonic Suite (Billings and Billings, 1975; Lyons and others, 1997). Gneisses and amphibolites of the Ordovician Ammonoosuc Volcanics lie immediately east and west of the valley floor (Billings and Billings, 1975; Lyons and others, 1997). Pegmatite of the Devonian New Hampshire Plutonic Suite locally cuts the Oliverian and Ammonoosuc rocks (Billings and Billings, 1975).

Two lineaments (fig. 1) identified from high-altitude areal photographs pass near the cell-house site along the riverbank, and towards the southern end of the site (Ferguson and others, 1999). Certain types of lineaments, particularly certain fracture-correlated lineaments, have been associated with more transmissive bedrock in New Hampshire (Moore and others, 2002).

Overburden in the area (Olimpio and Mullaney, 1997) is generally less than $20 \mathrm{ft}$ thick and consists of thin deposits of glacial till (an unsorted mixture of clay, silt, sand, cobbles, and boulders). At the cell-house site there is also demolition debris including concrete, metal, and other building materials. Glacial till covers bedrock on the valley floor and valley walls where slopes are gentle, but is generally absent along the Androscoggin River near the site.

\section{Methods}

Site characterization consisted of detailed geologic mapping, geophysical surveys, and ground- and surface-waterlevel monitoring from October 2002 through February 2004. Potentially transmissive zones are indicated by observation of physical properties and integrated analysis of various information. Information used includes detecting fracture patterns in specific rock units, observing water movement in a borehole, or inference from measuring geophysical differences in rocks or fluids in the rock.

Detailed geologic mapping and geophysical surveys on the riverbank at the western edge of the cell-house site were based on a $70 \times 540-\mathrm{ft}$ stable data-collection reference grid created using rock bolts installed in holes drilled into the riverbank bedrock (fig. 2, plate 1). Columns in the grid trend N. $30^{\circ}$ E. and are identified with letters (A-F) from east to west in 10-ft increments. Rows are identified with numbers (1-54) in 10-ft increments from north to south. The locations of 23 reference-bolts set into the riverbank bedrock are shown on plate 1 .

\section{Geologic Mapping and Analysis}

Investigation of ground-water flow in crystalline bedrock involves understanding the characteristics and patterns of fractures in the rock. Measurements of fractures alone, however, will not provide an understanding of the basis for variations in fractures at a site. Fracture characteristics, including relative amounts and orientations, have been found to be related to rock type in the crystalline rocks of New Hampshire (Walsh and Clark, 2000). Geologic mapping, in addition to measuring fracture characteristics, included descriptions of rock characteristics such as grain composition, size, shape, color, and texture. Changes in rock type, internal structure, and grain size may be associated with considerably different fracture characteristics. Basic rock characteristics are needed to develop an understanding of the potential for fracturing in areas where rock is not exposed at the lands surface, and needs to be interpreted from cores or where the rock characteristics are inferred from geophysical surveys.

In 2002 and 2003, the geology of the Androscoggin riverbank at the cell-house site was mapped at a 1:120 scale. General characteristics of 15 bedrock outcrops in a 1-mi radius of the site were mapped in less detail. Rock lithologies were examined visually, with a hand lens, to identify rock types and minerals, and estimate of the percentages of minerals present. Bedrock cores from boreholes at P-4A, MW-7, MW-8, MW-9 and MW-10 (appendix 1), and geologists logs from MW-14 and MW-15 (Joseph Schmidl and Joe Souney, Weston Solutions, Inc., written commun., 2004), were examined for general rock lithology and fracture characteristics.

The orientation of all brittle structures with trace lengths greater than $20 \mathrm{~cm}(8 \mathrm{in}$.) (Barton and others, 1993) and ductile structures were measured in the grid cells at the cell-house 
site and at selected outcrops in the Berlin area, following objective "station-mapping" procedures described in Spencer and Kozak (1976) and Walsh and Clark (2000). Brittle structures were defined as all fractures, fracture sets, fracture zones, and faults. The term fracture, as used in this report, includes joints and partings along ductile fabric. Faults are indicated where evidence, such as displaced markers along fractures or slickensides on fracture surfaces, are present. Ductile structures measured included axial planes of folds, fold axes, and foliation. Strikes are discussed in "right-hand-rule" format. By this convention, with your right hand palm up and your right thumb pointing in the dip direction, your index finger will point in the strike direction.

Brittle structures with dips equal to or greater than $60^{\circ}$ (Mabee and others, 1994) were plotted as normalized azimuth-frequency histograms (rose diagrams) (Wise and others, 1985, Salvini and others, 1999). Rose diagrams are useful for providing visual and statistical analyses of orientation patterns in steeply dipping structures by using strike measurements only. Principal peaks (identifying prominent fracture trends) on normalized azimuth-frequency plots are those peaks greater than 50 percent of the highest peak (Hardcastle, 1995). Brittle structures with dips less than $60^{\circ}$ and ductile structures (foliation) were plotted as poles to planes on an equal-area stereonet. Stereonets (fig. 3, also known as a stereogram) provide a useful means for visualizing and statistically evaluating the orientations of planar features, particularly features with shallow dip angles. The plots describe the orientations of planar surfaces and the fold axes orientations of folded planar features. The line of intersection between two fracture planes forms an intersection lineation. The orientation of this lineation was measured directly or calculated from measurements of intersecting fracture planes and plotted as a pole to represent the trend and plunge with a stereonet.

\section{A. Three-dimensional fracture plane intersecting the lower hemisphere and the projected pole to the plane}

\section{B. Stereonet of A}

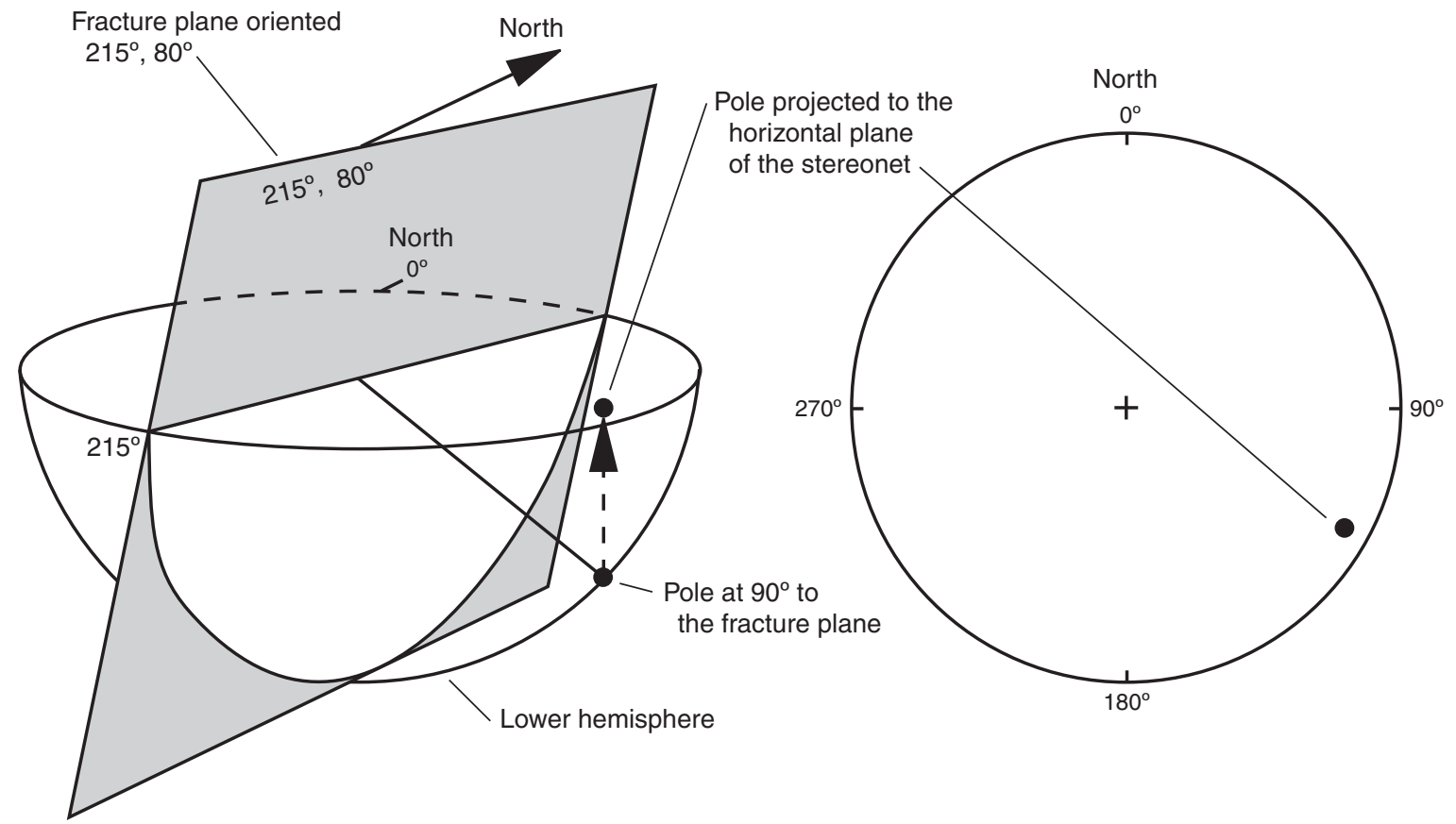

Figure 3. Schematic diagram of lower hemisphere stereonet projections. The stereonet projection reduces the orientation of a fracture plane to a point on a stereonet by plotting the pole to the plane on a lower hemisphere and projecting it up to the horizontal plotting surface of the diagram. The schematic (A) shows a three-dimensional representation of the fracture plane as it intersects the hemisphere and the projected pole to a plane that strikes $215^{\circ}$ and dips $80^{\circ}$, and (B) shows the stereonet that would correspond to example (A). (Modified from Johnson and others, 1999.) 
A stereonet is the projection of the lower hemisphere of a sphere to a horizontal plane. In stereonets (fig. 3), the orientation of a plane can be described by the orientation of a line perpendicular to that plane. A line perpendicular to that plane pierces the lower hemisphere at a point called a "pole." The projection of lower-hemisphere poles (representing planes) to a stereonet produces a plot that allows comparison of the orientation of many planes. A concentration of poles indicates a uniform orientation of structures. A circular trend line (termed great circle) fit to dispersed poles can indicate folding in a set of planar structures. The pole perpendicular to the plane defined by this circle shows the orientation of the fold axis for cylindrical folds.

\section{Hydrogeologic Analysis}

Ground-water level and river-stage data were used to assess the connectivity of the ground-water-flow system at the cell-house site with the river and to estimate general, or bulk, hydraulic conductivities of the rock. These data were collected during 2002 and 2003 and evaluated to determine ground-water-flow directions, gradients, and hydraulic interactions between the bedrock, overburden, and surface water. Monitoring included continuous (5- to 15-minute intervals) and monthly measurements of river stage, ground-water level, specific conductance, and water temperature. Changes in ground-water specific conductance and temperature were used to indicate periods when ground and surface water interact. Monthly measurements at additional sites also were used to supplement spatial coverage of continuous measurement sites. Synoptic surveys of all of the wells and piezometers at the site were used to create potentiometric-head maps of ground water in the overburden and bedrock representing high and low water-level conditions.

\section{Surface Water}

The Androscoggin River stage, specific conductance, and temperature was continually monitored (5- to 15-minute intervals) at surface-water measuring point (SW) SW-1 (fig. 2) from November 2002 through September 2003. Observations of the canal stage were obtained from measurements collected by Berlin Power (Donald Mercier, written commun., 2004) every 60 minutes. Periodic measurements of canal and river stage were collected at SW-2 and SW-3 during synoptic surveys (fig. 2).

\section{Ground Water}

Water levels at eight wells were continuously monitored at 5- to 15-minute intervals at bedrock wells MW-7, MW-8, MW-9, and P-4A; and overburden wells MW-2, MW-5, MW-3, P-21, and MW-4 (fig. 2). All wells are 2 in. in diameter, except P-21 and P-4A, which are 0.75 in. in diameter.
Ground-water specific conductance and temperature was measured every 5-15 minutes at MW-7. Well-construction information is provided in table 1 .

Individual water-level measurements were made to create potentiometric-head (water-level) maps. Directions and magnitudes of head gradients were calculated from measured heads. The predominant head direction and magnitude were calculated according to methods described by Delvin (2003).

\section{Hydraulic Analysis}

River-stage-induced bedrock-head fluctuations were analyzed to (1) assess the hydraulic connections between the bedrock aquifer and the river and (2) estimate bulk hydraulic properties of the bedrock. Bulk hydraulic properties are the effective hydraulic conductivity over a large volume of highly fractured and less fractured bedrock. To isolate river-aquifer interactions, daily precipitation records were reviewed to identify periods when stage increases were measured during periods with no precipitation. Stage fluctuations during these periods represent changes in streamflow from upstream regulation. A minimum period of no precipitation of 3 days was used to insure that delayed infiltration from precipitation would not affect ground-water levels. Ground-water-level rises during this time would indicate a hydraulic connection between the river and the well. Levels that are highly correlated with river stage indicate a direct connection between the aquifer and the river and allow bulk hydraulic properties of the bedrock to be estimated. The estimated bulk properties represent an integrated value for the region between the river, which is essentially a horizontal line source, and the well, a horizontal point source.

River-stage and head fluctuations were assessed using an analytical solution for stream-aquifer interactions (Barlow and Moench, 1998). Bedrock hydraulic properties were estimated by adjusting the fit of computed to observed bedrock-head fluctuations. For simplification of numerical calculations, the analytical solution assumes the following conditions: fully penetrating river, unconfined aquifer, homogeneous and isotropic flow system, flow is two-dimensional, wells partially penetrate the aquifer, and the aquifer width is assumed infinite.

Analytical model geometry was approximated from site conditions and includes a stream width of $50 \mathrm{ft}$ and length of $780 \mathrm{ft}$, and an aquifer width of $300 \mathrm{ft}$ and thickness of $100 \mathrm{ft}$. A vertical to horizontal ratio of 1 to 1 was assessed because the subhorizontal schist and pegmatite only approximate a layered condition locally. However, other ratios were tested with little affect on results, likely because the open interval of the bedrock wells straddle the elevation of the river bed incision, thereby making vertical anisotropy insensitive. Specific storage was assumed to be $1.0 \times 10^{-4} / \mathrm{ft}$ while horizontal hydraulic conductivity was varied from 200 to $0.02 \mathrm{ft} / \mathrm{d}$. Well-construction information is included in the solution to account for the screen depth of the bedrock wells. 
Table 1. Construction information for selected wells and stage monitoring sites, cell-house site, Berlin, N.H.

[Site location shown on figure 2. M.P., measurement point; MW, monitoring well; toc, top of outer casing; tpvc, top of inner casing; --, no data or not applicable; p, piezometer; swp, piezometer near or in the barrier wall; O, overburden; R, bedrock; S, slurry (barrier) wall] Note: Vertical coordinate information (altitude), as used in this report, refers to distance above the vertical datum using a survey datum of Tighe and Bond (2001) and can be converted to North American Vertical Datum of 1988 (NAVD 88)" by subtracting $4.73 \mathrm{ft}$.

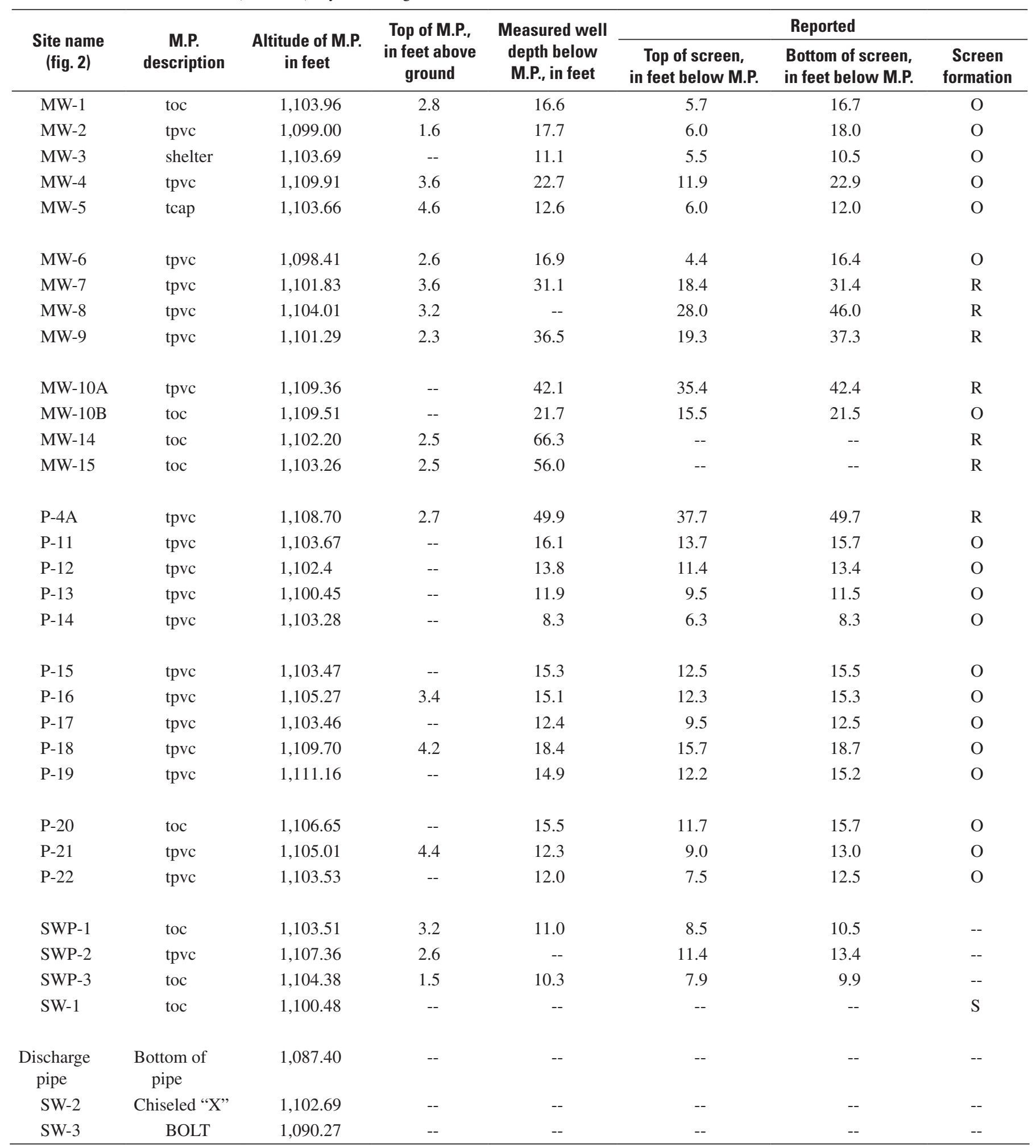




\section{Geophysical Surveys}

Geophysical surveys are used to identify and determine the orientation of planar features in bedrock, such as fracture zones, contacts, or other features (Powers and others, 1999; Degnan and others, 2001, Degnan and others, 2003). Geophysical surveys indicate features in the subsurface and require additional geologic or hydrologic information to confidently interpret the results. Physical changes in rock properties, such as variations in electrical resistivity caused by water-filled fractures, or variations in electromagnetic properties at a fracture interface, are used to indicate fractures in bedrock. Ground-penetrating radar and two-dimensional direct-current electrical resistivity were used at the riverbank, on the capped area, and at the perimeter of the site to characterize the subsurface at the study site. Square-array resistivity, which is used for indicating the predominant strike of bedrock fractures in a surveyed area, was attempted in November of 2002. Rapidly freezing ground conditions, however, caused data-acquisition errors, and timber storage at the site in the spring of 2003 prevented repeating the survey.

\section{Ground-Penetrating Radar}

Ground-penetrating radar (GPR) surveys along the riverbank were used to identify fractures from reflections of electromagnetic waves, and on the capped area to identify depressions in the bedrock surface where mercury could pool. The water content, overburden type, and lithology of materials can be inferred from the characteristics of GPR signals (Beres and Haeni, 1991). GPR surveys were collected with a 300-Megahertz frequency antenna, using a point-survey mode (rather than a continuous-collection mode) at 5-ft intervals along a line, and stacked to amplify weak reflections.

\section{Two-Dimensional Resistivity}

Two-dimensional direct-current electrical resistivity surveys at the riverbank and site perimeter were used to measure electrical properties of the bedrock. Resistivity surveys could not be performed on the capped area because the geomembrane electrically insulates materials beneath the membrane. On the riverbank, electrodes were placed in an absorbent fabric soaked in a saline solution to provide electrical contact with the rock. Dipole-dipole and Schlumberger-array (Zohdy and others, 1974) configurations were used with minimum electrode spacings (A spacings) of $5 \mathrm{ft}$ along the riverbank and 10 or $15 \mathrm{ft}$ along the site perimeter. Interpretations were based largely on the dipole-dipole arrays because it provides finer lateral resolution than Schlumberger arrays. However, the Schlumberger-array configuration provides a better signal to noise ratio (a robust data acquisition) and was used where the dipole-dipole arrays were missing large amounts of data.

Unprocessed resistivity data provides an apparent resistivity value which incorporates all layer resistivities beneath a point at the land surface to a depth largely controlled by the "A" spacing. Resistivity data were processed, using inver- sion techniques (RES2DINV version 3.52, Loke, 1999), to resolve data into possible geoelectric models by accounting for thicknesses and layer resistivities where known or estimated. Inversion was used to account for the effects of overburden materials on resistivity values at depth to aid interpretation of anomalies in the bedrock. Bathymetry data for the river pools were provided by GPR surveys, using a two-way radar velocity of 0.06 foot per nanosecond to create a fixed resistivity model layer (Loke and Lane, 2002). The conductivity of the water in the pool, used to constrain resistivity inversion, is about $40 \mu \mathrm{S} / \mathrm{cm}$ (resistivity of $800 \mathrm{ohm}-\mathrm{ft}$ ).

\section{Borehole Geophysical Logs}

Boreholes MW-14 and MW-15 were selected for logging because they were adjacent to areas of interest on the riverbank and the boreholes were temporarily left open (not screened off as were other wells at the site). Borehole-geophysical logs collected included natural-gamma radiation, electromagnetic (EM) formation conductivity, borehole fluid temperature and conductance, acoustic caliper, acoustic televiewer, and deviation (associated with the televiewer). Additionally, heat-pulse flowmeter measurements were collected at MW-15. Ambient flow was not detected in MW-15 and flow under low-flow pumping conditions (which can identify transmissive fractures) could not be measured due to freezing conditions. Results are referenced in feet below top of casing. Borehole-geophysical logging methods and interpretation are similar to those provided by Keyes (1990) and Johnson and others (1999).

Acoustic-televiewer logs were collected to determine the orientations of fractures and foliation in a borehole. The acoustic-televiewer logs were correlated with rock-coring logs (Joseph Schmidl and Joe Souney, Weston Solutions, Inc., written commun., 2004) and the orientation of identified features were corrected for borehole deviation and magnetic declination. Efforts to collect optical-televiewer logs, to directly observe the borehole wall, were not successful because the borehole water remained cloudy due to recent drilling. Planar features are presented in azimuthal degrees from true north as stereonets and tadpole plots. Stereonets (fig. 3) are useful for observing the overall trend of fracture or foliation orientations and tadpole plots allow individual features to be assessed with depth.

\section{Geologic Characterization}

Geologic characterization consisted of a general regional assessment in the Berlin area and a detailed local investigation of the riverbank outcrop at the cell-house site. The regional assessment was used to compare features seen at the cellhouse site with the surrounding area in an effort to determine the regional extent of features seen on site. The 1-mi radius around the cell-house site, termed the Berlin area for this investigation, was the area of the regional assessment (fig. 4). 


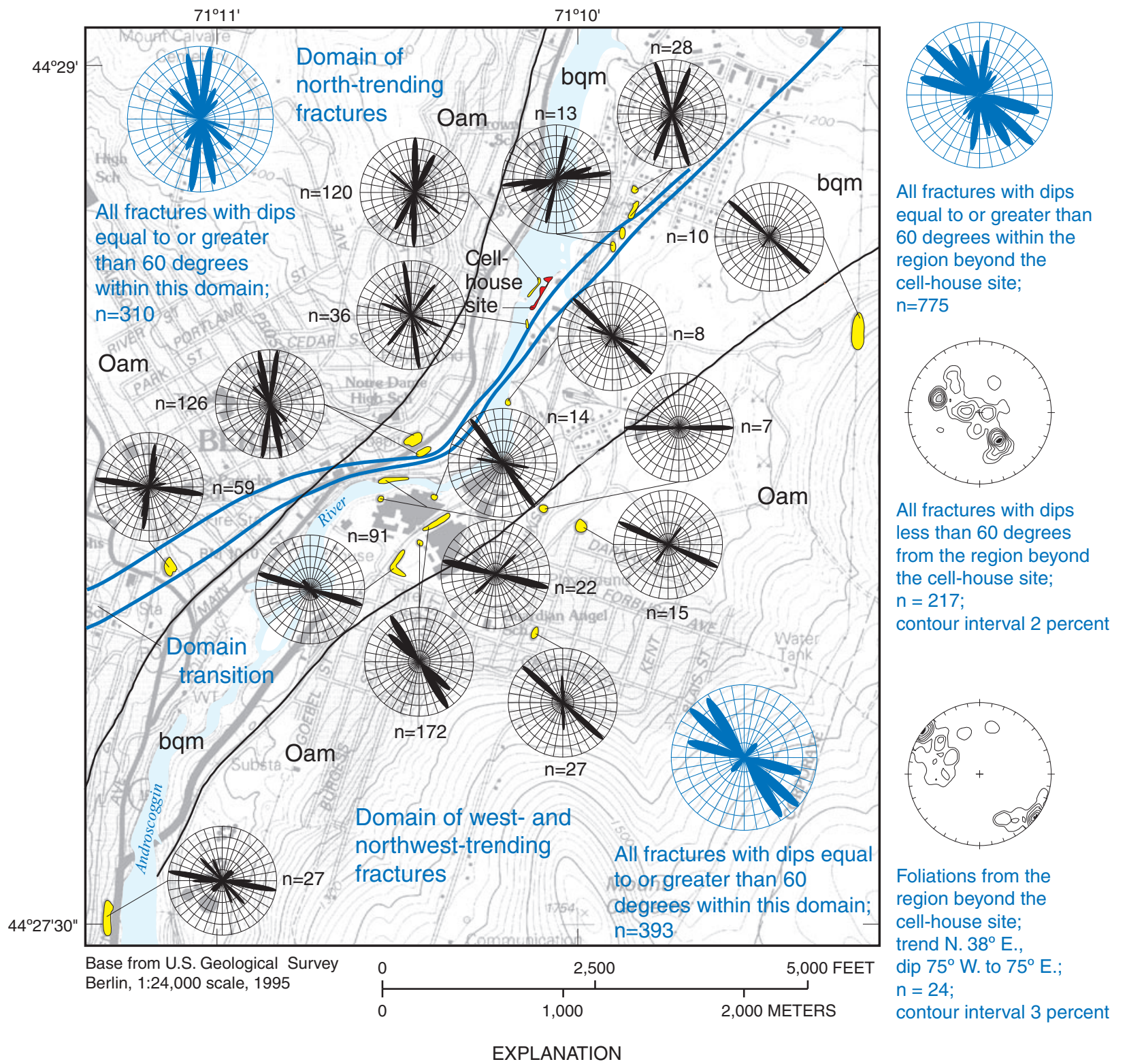

\begin{tabular}{|c|c|}
\hline bqm & Oliverian Plutonic Suite \\
\hline Oam & Ammonoosuc Volcanics \\
\hline 0 & Outcrops examined near the cell-house site \\
\hline 8 & Outcrop examined at the cell-house site \\
\hline & Fracture domain boundaries \\
\hline
\end{tabular}

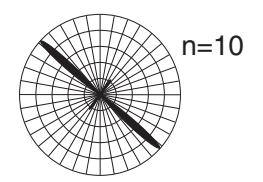

Normalized azimuth-frequency plot for all fractures dipping equal to or greater than 60 degrees;

$\mathrm{n}$ equals number of structures measured

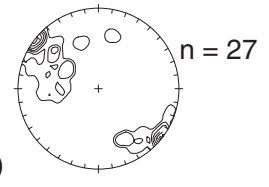

Lower hemisphere stereonet plot of poles to planes.

Contours in percent per 1 percent area; $\mathrm{n}$ equals number of structures measured

Figure 4. Bedrock geology, azimuth-frequency plots of fractures, fracture domains, and foliation near the cell-house site, Berlin, N.H. 


\section{Berlin Area}

Bedrock in the Berlin area is primarily composed of the Oliverian Plutonic Suite and the Ammonoosuc Volcanics. Billings and Billings (1975) describe the Oliverian Plutonic Suite as primarily pink, foliated, medium- to coarse-grained, granoblastic-textured quartz monzonite and pink pegmatite. The Ammonoosuc Volcanics are fine-grained, light-gray, foliated biotite gneiss locally interlayered with hornblende amphibolites. The units are distinguished by the finer grained, locally fragmental and bedded nature of the Ammonoosuc Volcanics and pink character of the Oliverian gneisses. The Oliverian Plutonic Suite intrudes the rocks of the Ammonoosuc Volcanics. Pink pegmatites of the New Hampshire Plutonic Suite locally cut the Oliverian and Ammonoosuc rocks (Billings and Billings, 1975).

Examination of 20 outcrops within a 1-mi radius of the cell-house site (fig. 4) support the division of units presented by Billings and Billings (1975). The narrow belt of rocks trending north-northeast through Berlin is dominated by Oliverian Plutonic Suite lithologies. Amphibolites of the Ammonoosuc Volcanics, believed to be xenoliths, are found within the area mapped as Oliverian Plutonic Suite rocks. For example, amphibolite (dark green to black, fine-needle, hornblende-plagioclase gneiss) xenoliths occur along Route 16 , about $1,000 \mathrm{ft}$ north of the hospital shown on the 7.5minute, Berlin, N.H., topographic map. Dark-gray to black hornblende-biotite gneiss with biotite porphyroblasts also are present in rocks mapped as Oliverian in outcrops east of the entrance to the Berlin pulp mill. Unmetamorphosed lamprophyre dikes contain xenoliths of gray gneiss and pink feldsparbearing gneiss and occur in outcrops east of the entrance to the Berlin pulp mill (about 1,000 ft south of the cell-house site).

\section{Ductile Structures}

First stage of folding (F1) in the Berlin area (Billing and Billings, 1975) produced northeast trending open, tight, and isoclinal folds and an axial plane foliation (S1). Second stage of folding (F2) is marked by folded foliation in the Oliverian Plutonic Suite. The body of Oliverian gneiss trending northeast through Berlin, an anticline overturned to the northwest, is flanked by overturned synclines of Ammonoosuc Volcanics (Billings and Billings, 1975). Foliation (S1) measured in the 20 outcrops in the Berlin area trends N. $38^{\circ}$ E., dipping steeply east or west (fig. 4). The S1 foliation and F2 folding are recognized at the cell-house site.

At various locations in the Berlin pulp mill (immediately south of the cell-house site), and south and west of Berlin, gray Oliverian gneiss contains $10-20 \mathrm{~cm}(4-8$ in.) thick zones of chlorite schist that are parallel to the S1 foliation. The schist may be the result of retrograde metamorphism of amphibolite enclaves, xenoliths, or dikes. Narrow zones of chlorite schist associated with open vugs and fractures found in the regional reconnaissance are similar to structures seen at the cellhouse site.

\section{Brittle Structures}

Analysis of steeply dipping fractures in the Berlin area identifies two distinct fracture domains (fig. 4), which are areas defined by and containing distinct fracture patterns. South and east of the Androscoggin River, principal peaks on normalized azimuth-frequency plots trend west or northwest. West and north of the river (fig. 4), principal peaks trend northward or north-northeast. At two localities west of the river, west-northwest and west-southwest principal peaks are present in addition to the north-trending principal peaks. East of the river, however (fig. 4), there are no north-trending principal peaks present. The presence of both generally west and north-trending principal peaks at the two localities indicates that domain overlap occurs at these outcrops. The domain boundary and transition zone generally trends northeast along the river. The cell-house site is near the boundary between the domains observed in Berlin (fig. 4).

\section{Cell-House Site}

The cell-house site is underlain by biotite-bearing quartz monzonite gneiss and granitic pegmatite (plate 1). Medium- to light-gray weathering, fine- to coarse-grained feldspar-quartzbiotite-chlorite \pm muscovite gneiss lacks distinct gneissic banding or compositional layering. The gneiss varies from coarse to fine-grained (fig. 5). In coarse-textured gneiss, planar micaceous patches (15-20 percent of volume) define a weak foliation (gneissosity) in this rock. Although the mica patches are not continuous, a planar surface representing gneissosity, defined by the consistent orientation of the mica plates, can be measured. Locally, micaceous segregations wrap around feldspar or quartz aggregates producing a weak flaser-texture. In other places, the texture of the gneiss is uniform. Irregular aggregates of feldspar or quartz between micaceous segregations composed of $0.2 \mathrm{~mm}$ (0.079 in.) rounded grains have a granoblastic texture.

The fine-grained gneiss is white and consists mostly of $0.2 \mathrm{~mm}$ (0.079 in.) glassy quartz and feldspar grains with 3-5 percent fine-grained biotite in small patches. Fine-grained gneiss locally contains well-developed sets of uniformly spaced fractures in contrast to the coarse-grained gneiss, which lacks these features (fig. 5). Contacts between the coarse- and fine-grained gneiss are gradational over 5-10 ft. These contacts were not shown on plate 1 because of their gradational nature and because the rusty-brown river-stained nature of the outcrop prevents a clear view of the fine details in the pattern of this contact.

Pegmatite is present as small dikes, $10-70 \mathrm{~cm}$ (4-30 in.) thick, that cut gneissosity or trend parallel to gneissosity and as a single tabular body (plate 1). Small dikes, such as those in grid-cell B24 (plate 1) with an igneous texture of interlocking crystals (fig. 6), cut gneissosity and are likely part of the New Hampshire Plutonic Suite. Locally (grid-cells B26-B34, plate 1), other pegmatite dikes are generally parallel to the gneissosity. These dikes, bounded by fractures and slicken- 


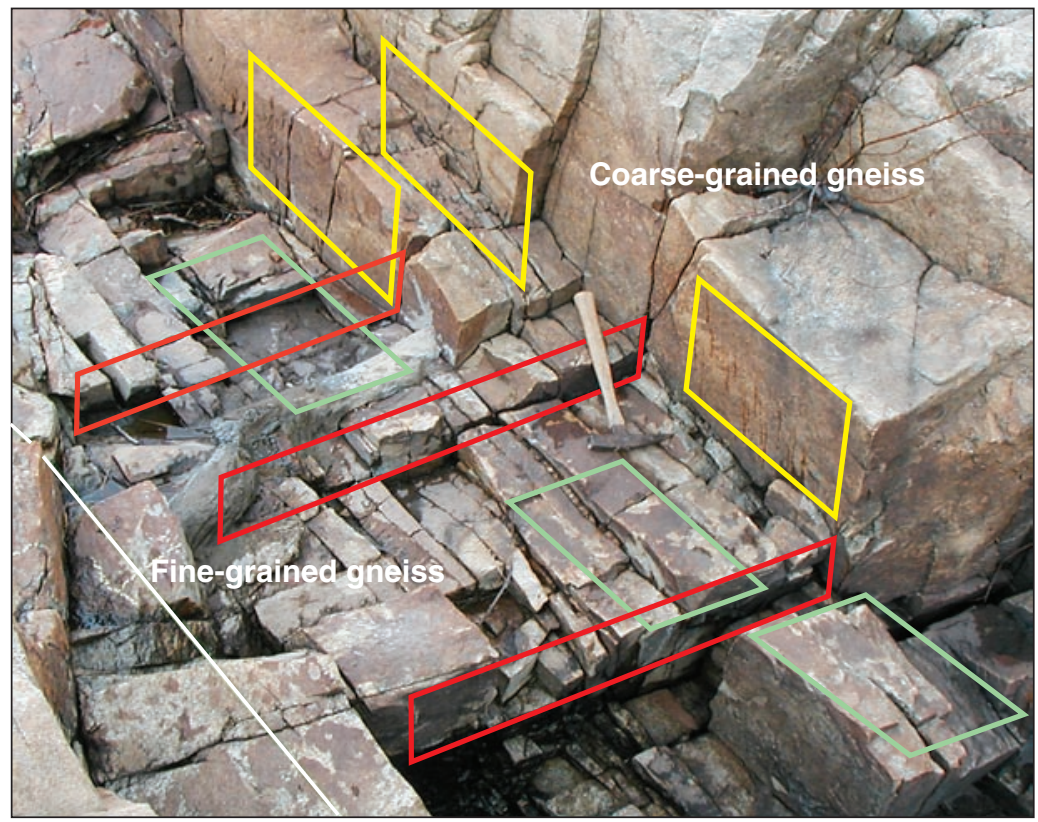

Figure 5. Fine-grained gneiss showing three sets of planar, parallel fractures from grid cell B21 (plate 1), view to southwest, at cell-house site, Berlin, N.H. (Planar-fracture sets are shown by three parallel colored rectangles for each set; white line is string tied between bolts marking grid-cell lines; scale shown by hammer near center of photograph.)

Figure 6. Trend of gneissosity in coarse-grained gneiss cut by pegmatite from grid cell B24 (plate 1), cell-house site, Berlin, N.H. (Scale shown by pencil.)

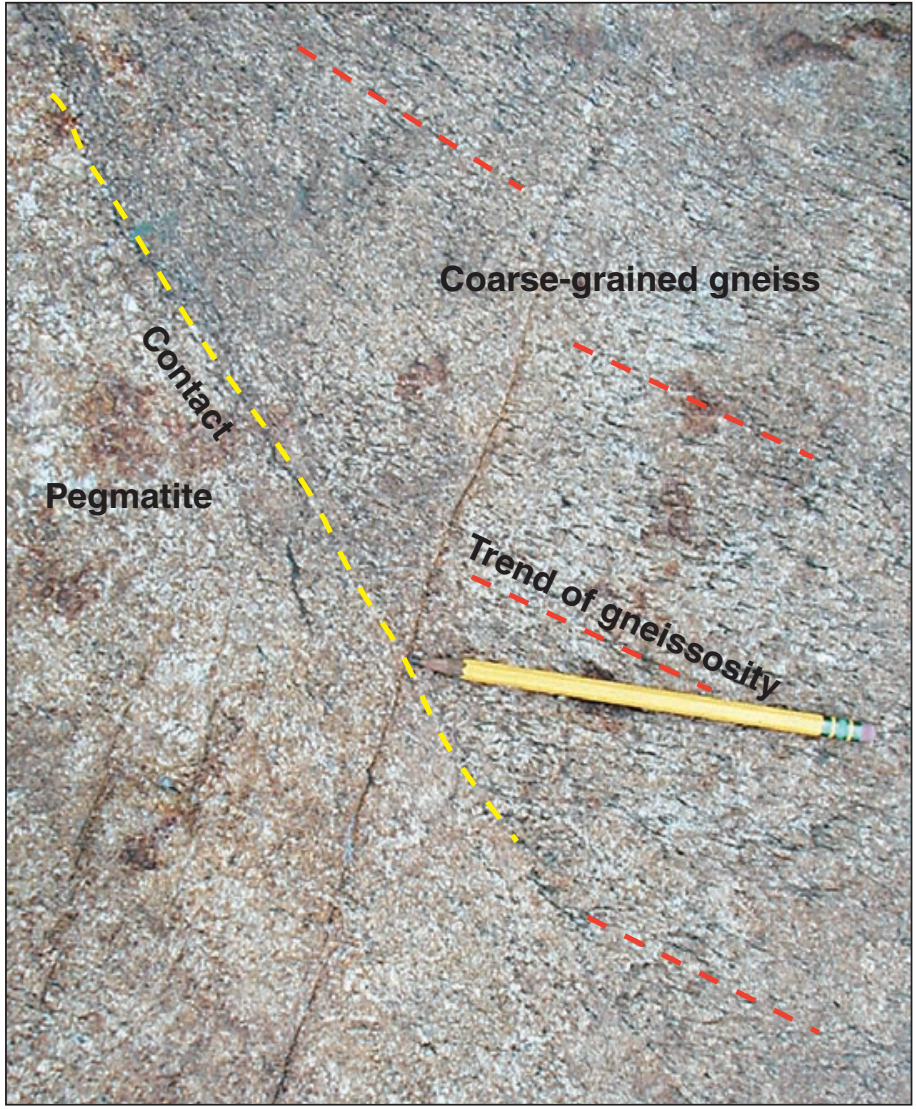




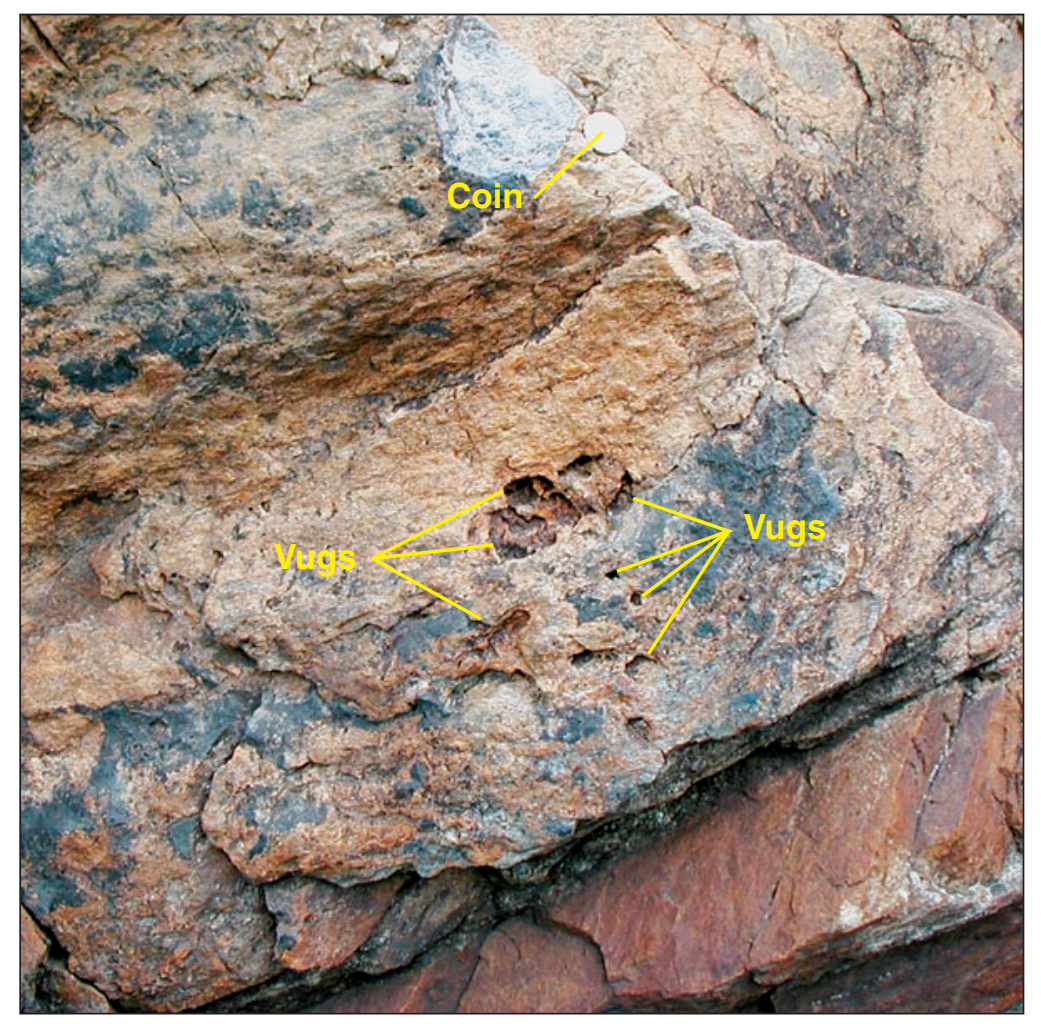

Figure 7. Vugs along the margin of chlorite-schist layer on a vertical outcrop face from grid cell B25 (plate 1), cell-house site, Berlin, N.H.

(Scale shown by dollar coin.)

sided fault surfaces, exhibit quartz and feldspar grain-size reduction and grain re-orientation indicating deformation was probably during or after dike intrusion.

Dark-green, medium- to coarse-grained, crenulated, chlorite schist is found throughout the cell-house site as discontinuous lenses ranging from 3- to 50-cm (1-20 in.) thick, which locally thin along strike and pass along strike into chloritebearing fractures. Hand specimens show the rock contains as much as 50-percent chlorite. Pink feldspar porphyroblasts up to $2 \mathrm{~mm}$ (0.08 in.) in diameter locally are in the chlorite schist. Along the margins of some chlorite-schist lenses, vugs up to 8 - $\mathrm{mm}$ in diameter contain small quartz crystals (fig. 7). The chlorite schist is extensively weathered and exhibits parting along the layering. The chlorite schist is found only in thin lenses throughout the cell-house site and the area of regional assessment. Most of the elemental mercury observed in the riverbank at the cell-house site is found in non-planar fractures (described in "Ductile Structures") associated with these chlorite schist lenses.

The chlorite-schist lenses are parallel to, and at high angles to, the foliation in the coarse- and fine-grained Oliverian gneiss, indicating that there may be more than one age of chlorite schist. In grid cells B24 and B28 (plate 1), the chlorite-schist lenses and chlorite-bearing fractures post-date pegmatite dikes and folds. Chlorite schist that is generally parallel to the foliation may have originated as either mafic enclaves or xenoliths in the Oliverian gneiss, or as small ductile shear zones in the plane of the gneissosity. Other chlorite-schist lenses may have been mafic dikes that post-date both Oliverian gneiss and pegmatite. Regardless of their origin, the current composition of the chlorite schist indicates that the original mafic rocks underwent retrograde metamorphism.

\section{Ductile Structures}

Foliation (S1 gneissosity) in gneiss and minor folds in chlorite schist at the cell-house site are ductile structural features shown in stereonets (fig. 8). F2 folding is present at two scales. A broad, larger than outcrop-scale structure folds gneissosity, chlorite-mineralized non-planar fracture and chlorite-schist lenses at the river bank outcrop. At the outcrop scale (plate 1), minor asymmetric folds are found within the chlorite-schist lenses. 
A. Poles to gneissosity.

Best fit great circle defines fold axis that plunges N. $48^{\circ}$ E., $34^{\circ}$.

Number of measurements, 37.

Each dot represents 1 unless noted otherwise.

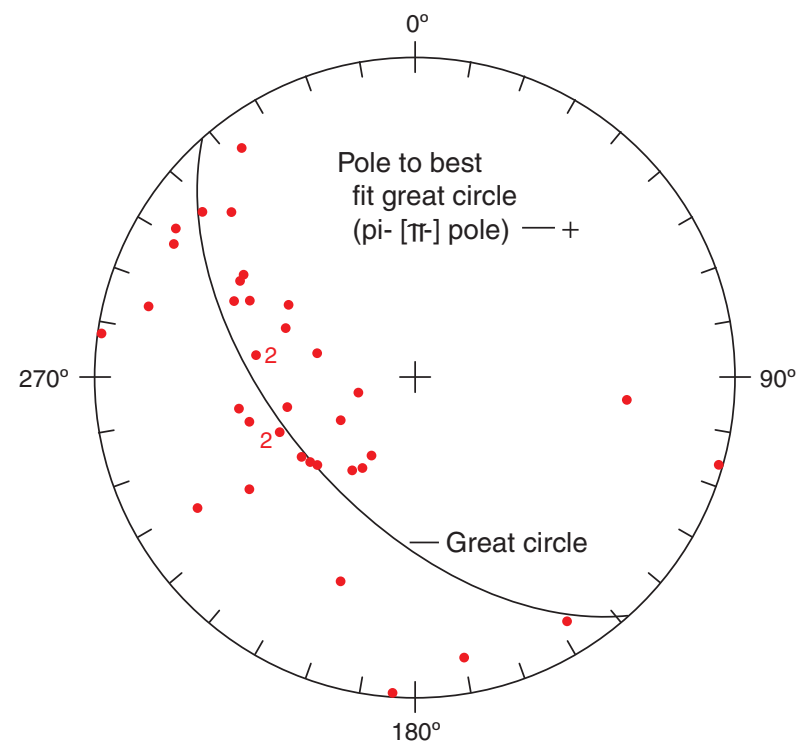

C. Poles to all non-planar fracture and chlorite schist lenses.

Best fit great circle defines fold axis that plunges

N. $55^{\circ}$ E., $47^{\circ}$.

Number of measurements, 100.

Each dot represents 1 unless noted otherwise.

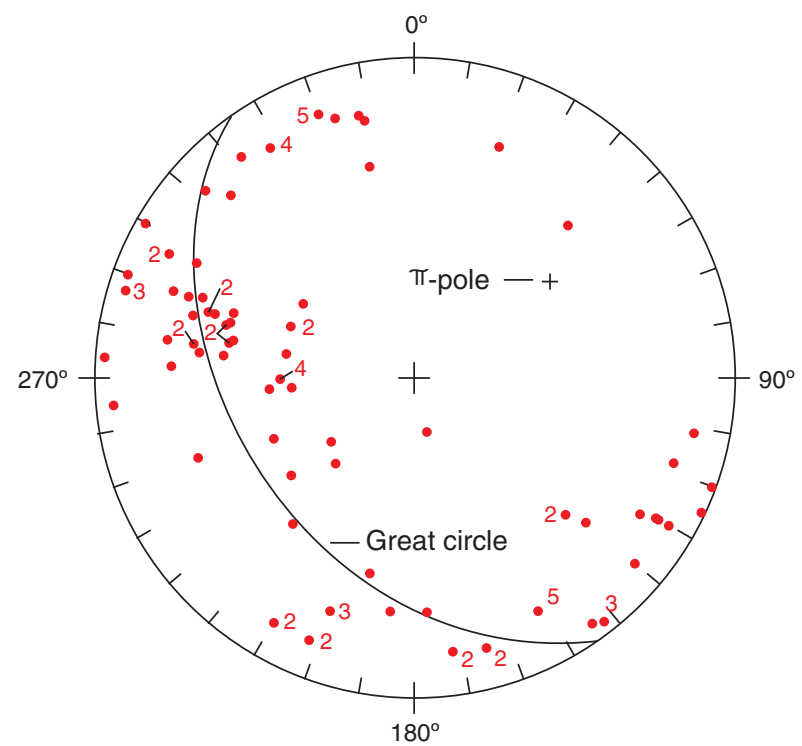

B. Poles to chlorite-mineralized fractures and chlorite schist lenses.

Best fit great circle defines fold axis that plunges N. $37^{\circ}$ E., $26^{\circ}$.

Number of measurements, 44

Each dot represents 1 unless noted otherwise.

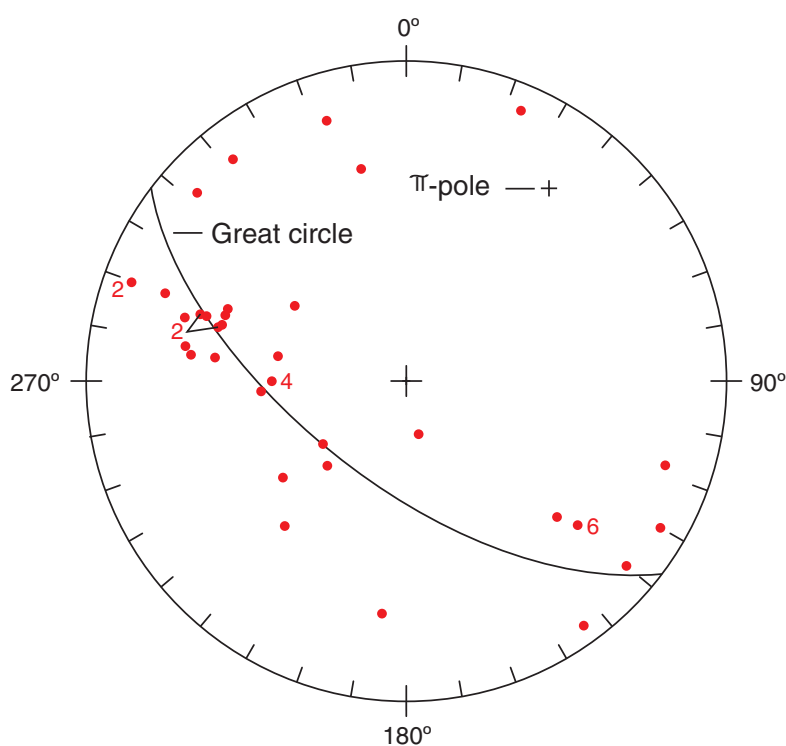

D. Axes of F2 minor folds, F2 crenulations, long axes of rods and vugs.

Maximum concentration plunges N. $29^{\circ} \mathrm{E} ., 30^{\circ}$.

Number of measurements, 92.

Contour interval is 5 percent; maximum point is 32 percent.

Each dot represents 1 unless noted otherwise.

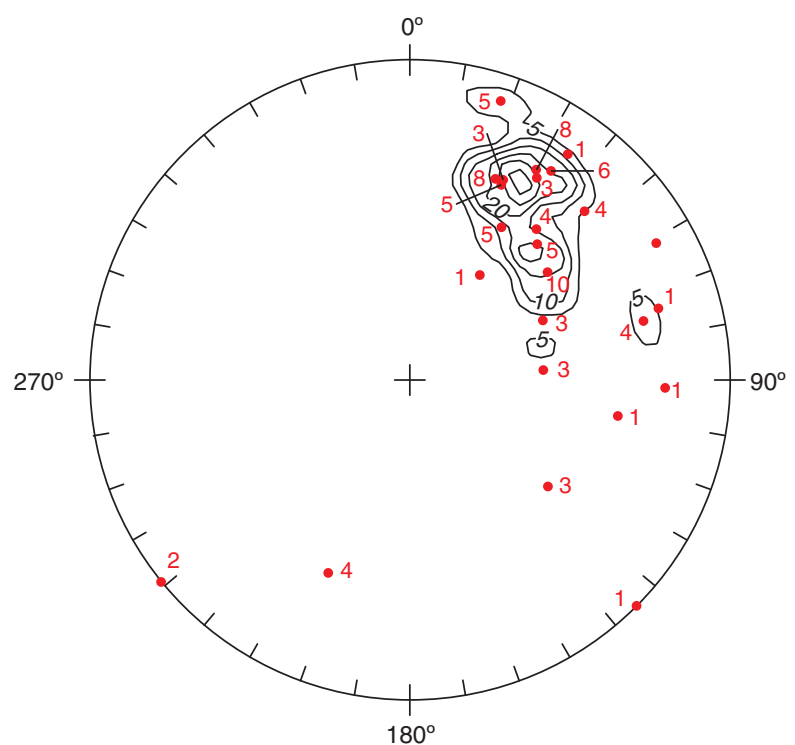

Figure 8. Stereonet plots for ductile structures in the bedrock outcrop at the cell-house site, Berlin, N.H., for (A) poles to gneissosity, (B) poles to chlorite-mineralized fractures and chlorite-schist lenses, (C) poles to all non-planar fracture and chlorite-schist lenses, and (D) axes of minor folds, crenulations, and long axes of rods and vugs. 


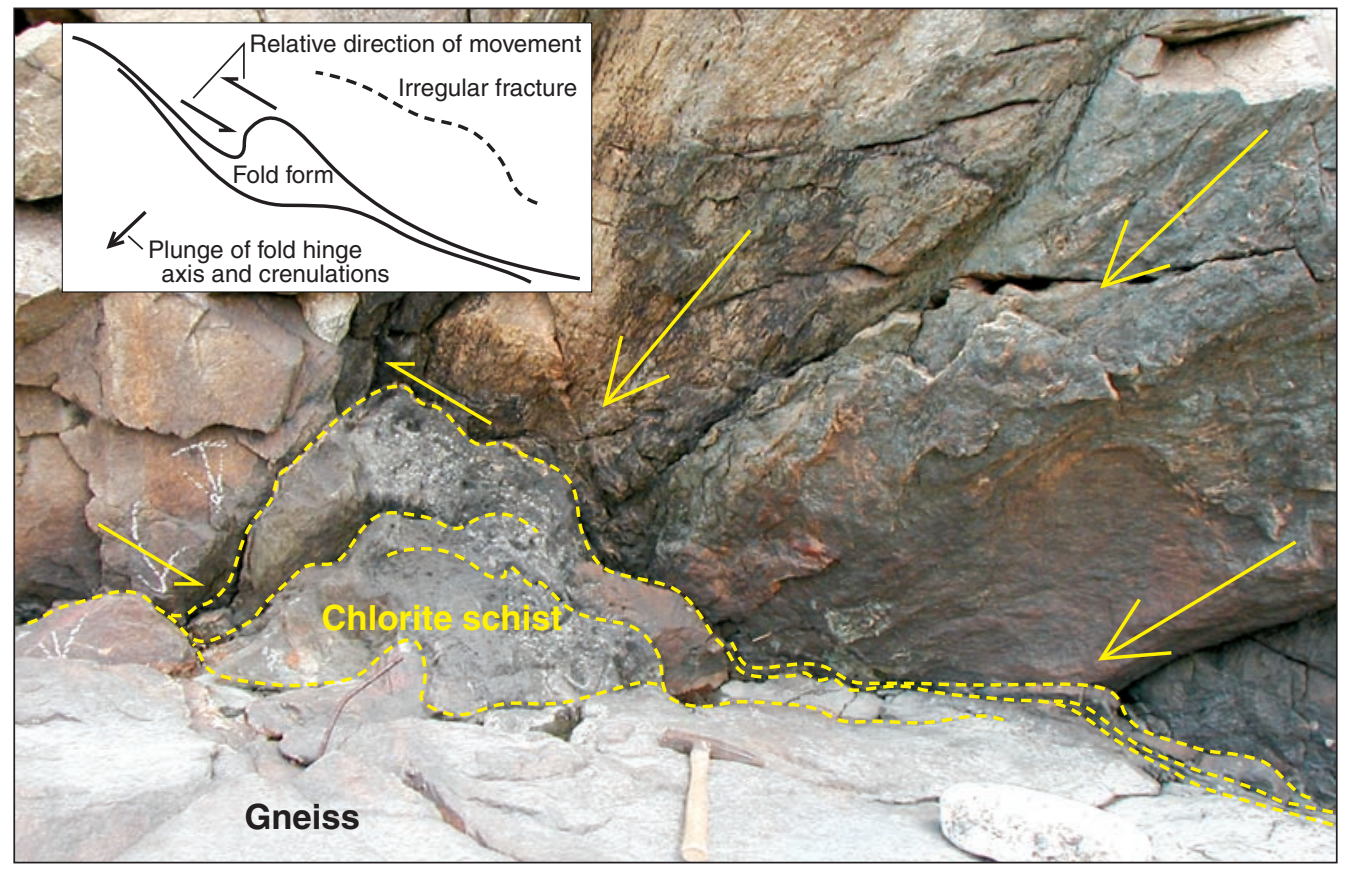

Figure 9. Fold hinge in asymmetric F2 fold in chlorite-schist lenses, cross section view to northeast, in grid cell B25 (plate 1), cell-house site, Berlin, N.H. (Scale shown by hammer in the foreground.)

Coarse-textured gneiss contains elongate discontinuous crenulated patches of biotite and chlorite that form a linear pattern (lineation) in the gneiss. A poorly developed planar foliation fabric (gneissosity) is defined by the flat surfaces of these micaceous patches. Billings and Billings (1975) describe similar findings and note that lineation may be present where there is no foliation or may be part of the foliation. Gneiss at the site locally exhibits parting along this foliation. Weathering, water staining, and the poorly developed nature of the gneissosity prevent detailed mapping of this fabric.

$\mathrm{F} 1$ folding produced the $\mathrm{S} 1$ gneissosity at the site and deformation of this gneissosity is associated with F2 folding (Billings and Billings, 1975). A stereonet of poles to gneissosity (fig. 8a) shows a girdle plot indicating folding of gneissosity with an $\mathrm{F} 2$ fold axis plunging $34^{\circ}$ in a N. $48^{\circ} \mathrm{E}$. direction. The orientation of gneissosity and the orientation of the F2 fold axis at the cell-house site are consistent with the folding of gneissosity found in Oliverian rocks in the Berlin region (Billings and Billings, 1975).

Nonplanar (irregular) fractures, defined by long wavelength (1-2 m (3-7 ft)) and low amplitude (10-20 cm (4-8 in.)) open folds, form isolated fractures. The nonplanar fractures locally have open aperture ( $1 \mathrm{~mm}(0.04 \mathrm{in})$.$) , are$ throughgoing structures, and contain discontinuous chlorite mineralization. Chlorite-schist lenses, 3 to $50 \mathrm{~cm}$ (1-20 in.) thick, locally decrease in thickness along strike and pass directly into surfaces mapped as chlorite-mineralized nonplanar (irregular) fracture. A stereonet of poles to the trend of chlorite-schist lenses and chlorite-mineralized nonplanar fractures (fig. 8B) shows that these structures appear to be folded by a larger-than outcrop scale F2 fold with a similar orientation (plunges $\mathrm{N} .37^{\circ} \mathrm{E}$. at $26^{\circ} \mathrm{SE}$ ) to the feature that deformed the gneissosity. A stereonet of poles to all nonplanar fracture and chlorite-schist lenses (fig. 8C) shows a similar orientation (plunges N.55 E. at $47^{\circ}$ ). Similar orientations indicate that nonplanar (irregular) fractures, both chlorite-mineralized and non-mineralized, and chlorite-schist lenses are parallel or subparallel to gneissosity, and are folded by a larger than-outcrop scale F2 fold at the cell-house site.

Asymmetric F2 folds have small short-limb to long-limb ratios and display counter-clockwise rotation when viewed in a down-plunge direction (fig. 9). These folds notably deform the chlorite-schist lenses and the $\mathrm{S} 1$ foliation in the schist in grid-cells C23-C24 and B24-B26 (plate 1). Fold-axis orientations measured on these structures plunge gently to moderately northeast (fig. 8D). These folds correspond to Billings and Billings (1975) F2 folds on the southeastern flank of the Jefferson Dome.

In cells A26, A27, and B26, B27 (plate 1), boudinage and lens-shaped structures can be found on vertical outcrop surfaces that cut overlapping chlorite-schist lenses. Crenulations, here and in the foliation of the chlorite schist, are minor F2 
folds with an amplitude and wavelength of $2-3 \mathrm{~mm}(0.08$ 0.16 in.). Rodding observed on the foliation surface of the chlorite schist also is associated with these features. The rods and crenulations are parallel to axes of the asymmetric F2 folds. Fold axes of asymmetric folds in the chlorite schist, axes of crenulations in chlorite schist, rodding, long axes of vugs in the walls of chlorite-schist lenses, and boudinage axes cluster about an $\mathrm{F} 2$ lineation that plunges about $30^{\circ}$ in a N. $29^{\circ}$ E. direction (fig. 8D).

\section{Brittle Structures}

The riverbank outcrop at the cell-house site contains a variety of brittle structures that display a consistent pattern of orientation and association. Closely spaced individual fractures are shown as zones on the geologic map (plate 1). Fractures in the Berlin area have apertures generally less than a millimeter. Three styles of fractures with different apertures that are found in the riverbank outcrop at the cell-house site include 1-2 mm- (0.04-0.08 in.) aperture en échelon fractures, $1 \mathrm{~mm}$ - (0.04 in.) aperture nonplanar (irregular) fractures, and tight parallel fractures. En échelon fracture zones, parallel fracture zones, and faults cut the folded foliation of the gneiss at the site. Steeply dipping en échelon fracture zones, parallel fractures, and faults have a similar average strike ranging from $029^{\circ}$ to $044^{\circ}$ throughout the riverbank outcrop (figs. 10A-C). Two faults form the contacts of a cataclastic pegmatite that extends from grid-cell B26-B34 (plate 1).

Fracture density and style are related to rock type along the riverbank outcrop (plate 1). The tabular body of pegmatite at the north end of the riverbank (plate 1) is relatively unfractured compared to gneiss. Fractures present in the gneiss below this pegmatite terminate at the pegmatite-gneiss contact. Coarse-textured weakly foliated gneiss is fractured, but contains fewer isolated fractures and fewer fracture sets than finegrained gneiss, which is highly fractured (fig. 5). This fracturing is apparent at the center of the riverbank (rows 19 and 24, plate 1). For example, from grid-cell B19 to grid-cell B24 coarse-grained gneiss and pegmatite grade into fine-grained gneiss with three sets of regularly spaced, mutually perpendicular fractures (fig. 5). Fracturing in the chlorite-schist lenses is present along the boundaries of the lenses and along parting parallel to foliation within the lenses.

\section{Fracture Zones}

En échelon fracture zones are defined as the trend of the bounding envelope that contains a set of en échelon joints (fig. 11). Individual joints that make up an en échelon fracture zone typically have short lengths (5-20 cm (2-8 in.)) and are arranged in a parallel, staggered pattern. Spacing of en échelon joints in these zones ranges from 0.5 to $4 \mathrm{~cm}(0.2-1.5 \mathrm{in}$.). The joints within the en échelon fracture zones locally display apertures of 1-2 $\mathrm{mm}(0.04-0.08 \mathrm{in}$.), and as much as $5 \mathrm{~mm}$ (0.2 in.). The en échelon fracture zones generally range from 3 to $40 \mathrm{~cm}$ (1-16 in.) wide, are less than $3 \mathrm{~m} \mathrm{(10} \mathrm{ft)} \mathrm{long,}$ and terminate within the outcrop. A stereonet of poles to en échelon fracture zones at the cell-house site shows an average plane striking $224^{\circ}$ and dipping $84^{\circ}$ northwest (fig. 10A). Plotted on an azimuth-frequency plot, the principal trend of the fracture zones is $44^{\circ} \pm 6^{\circ}$ (fig. 10A). The azimuth-frequency plot for individual joints within the fracture zones shows a principal trend of $36^{\circ} \pm 6^{\circ}$ (fig. 10A). En échelon fracture zones terminate against nonplanar (irregular) fractures parallel to gneissosity. Locally, zones of planar, parallel, throughgoing (passing through the outcrop) fractures are parallel to the en échelon fracture zones. At grid-cell E12 (plate 1) an en échelon fracture zone merges into a set of parallel fractures from south to north along strike.

Planar parallel fractures, generally have little or no aperture, and are commonly found in throughgoing zones. Distinct zones of parallel fractures (plate 1) range in width from 50 to $150 \mathrm{~cm}$ (20-60 in.). Spacing of individual fractures in the zones is from 2.5 to $15 \mathrm{~cm}$ (1-6 in.). Examples of such zones can be found in rows 11-13 in the northern third of the grid and in column C, rows 17-21, and 36, 37 in the center of the grid (plate 1). A stereonet of the orientation of parallel fracture zones (one pole per zone) at the cell-house site shows an average strike of $209^{\circ}$, dipping $80^{\circ}$ west (fig. 10B). The azimuthfrequency plot for steeply dipping parallel joint zones shows principal trends of $29^{\circ} \pm 6^{\circ}$ and $42^{\circ} \pm 5^{\circ}$ (fig. 10B).

\section{Faults}

Faults mapped at the riverbank include dip-slip faults and strike-slip faults. Some of the faults contain quartz veins and pegmatite and are referred to as silicified zones or silicified pegmatite bearing zones. Two southeast striking, southwest dipping faults, with downdip slickensides cut through pegmatite lenses in grid-cells C8 and D9 (plate 1). Offset features were not identified in these faults. Slickensided faults in grid-cells A24, B24, B25 (plate 1) offset weak banding in the gneiss, which in combination with unidirectional roughness along the slickensides, allow the relative motion (plate 1) along the fault to be determined. A thin silicified zone (fig. 12) is cut and bounded by fractures in grid-cell A22 (plate 1). A thin zone of multiply sheared quartz veins (fig. 13) with local interleaved chlorite schist extends from grid-cell C28 through grid-cell B34.

Faults in the central region of the riverbank (including grid cells B26 through B31) occur as planar zones along the margins of pegmatite dikes (fig. 14). Pegmatite in this zone is silicified, has a cataclastic texture, and is associated with fine-grained gneiss. These faults are zones $30-50 \mathrm{~cm}$ (12-20 in.) wide and include the silicified pegmatite. The boundaries of the silicified zone are characterized by thin gouge zones and poorly developed slickensided surfaces. The concentration of fracturing in the gneiss decreases south and west of the silicified pegmatites at the center of the riverbank outcrop. These faults appear to bound areas with different fracture frequency. The principal trend of silicified zones is similar to the trends of en échelon fractures and parallel fracture zones 
A. Orientations for en échelon features

Contour interval 10 percent Maximum point is 26 percent

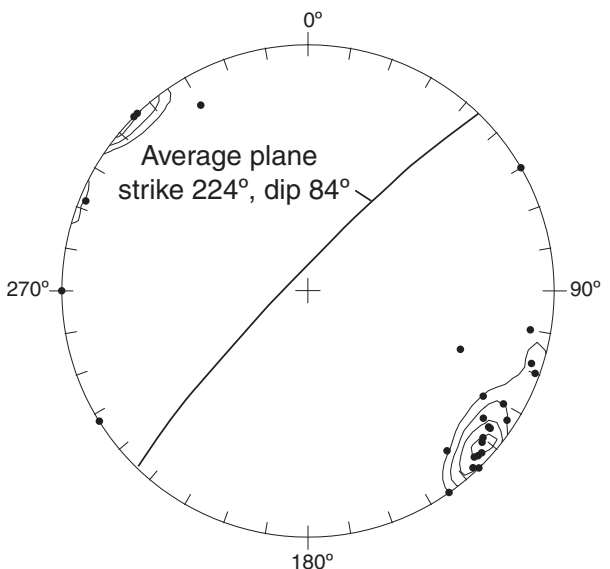

Poles to en échelon fracture zones; $n=26$

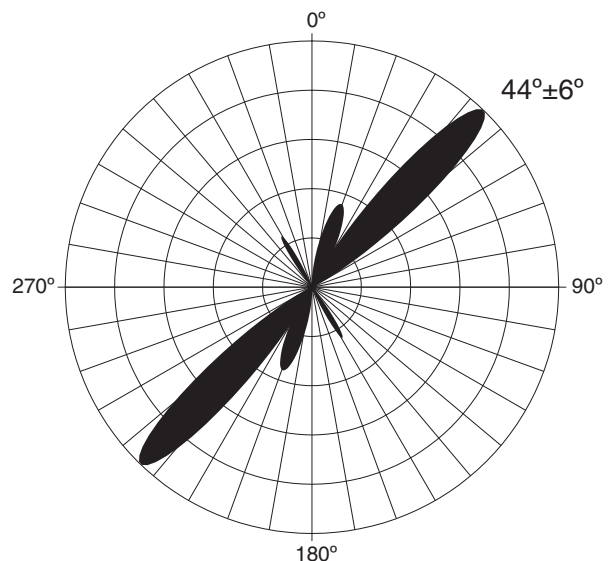

Normalized azimuth-frequency plot

of en échelon fracture zones; $n=26$

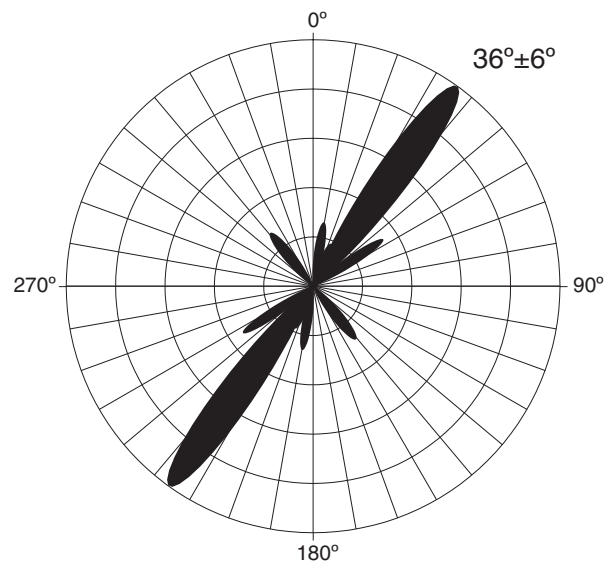

Normalized azimuth-frequency plot of en échelon fracture sets within the fracture zones; $n=45$

\section{B. Orientations of parallel fracture sets}

Contour interval 2 percent Maximum point is 26 percent $0^{\circ}$

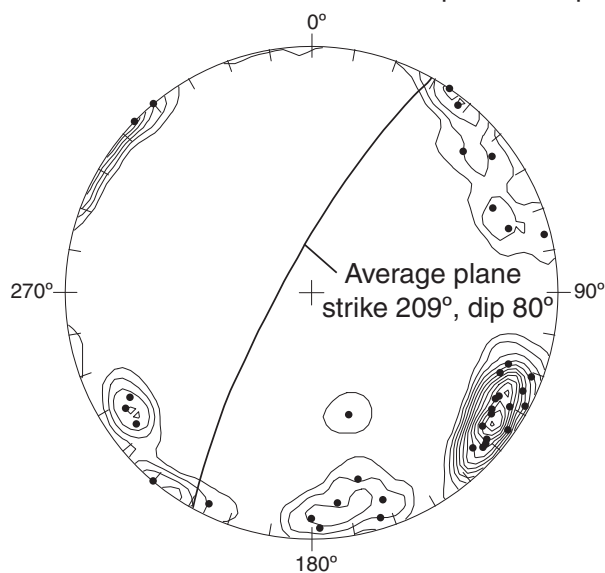

Poles to parallel fracture sets; $n=37$

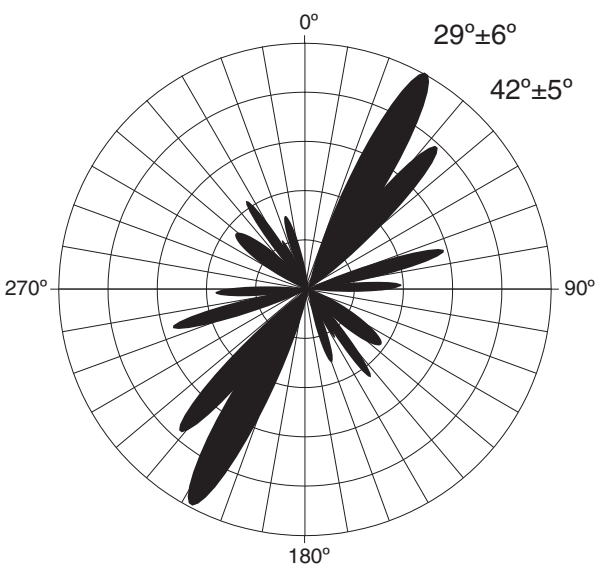

Normalized azimuth-frequency plot of parallel fracture sets; $n=37$

\section{Orientation of brittle faults}

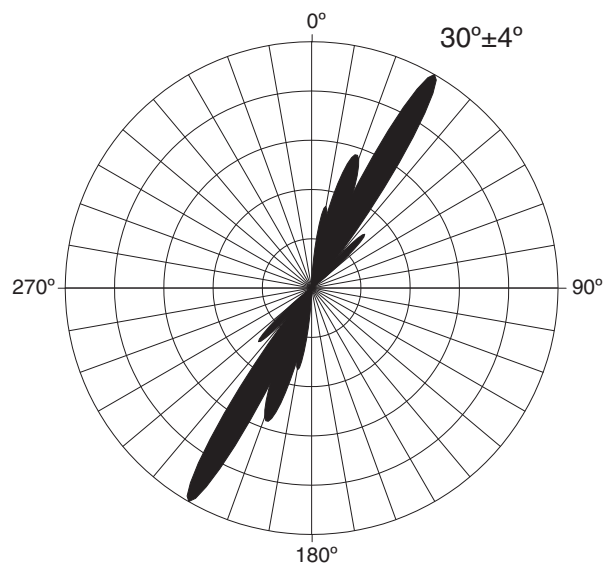

Normalized azimuth-frequency plot of brittle faults; $n=48$

Figure 10. Stereonets and azimuth-frequency plots for orientations of planar structures in the bedrock outcrop at the C measurements.) 


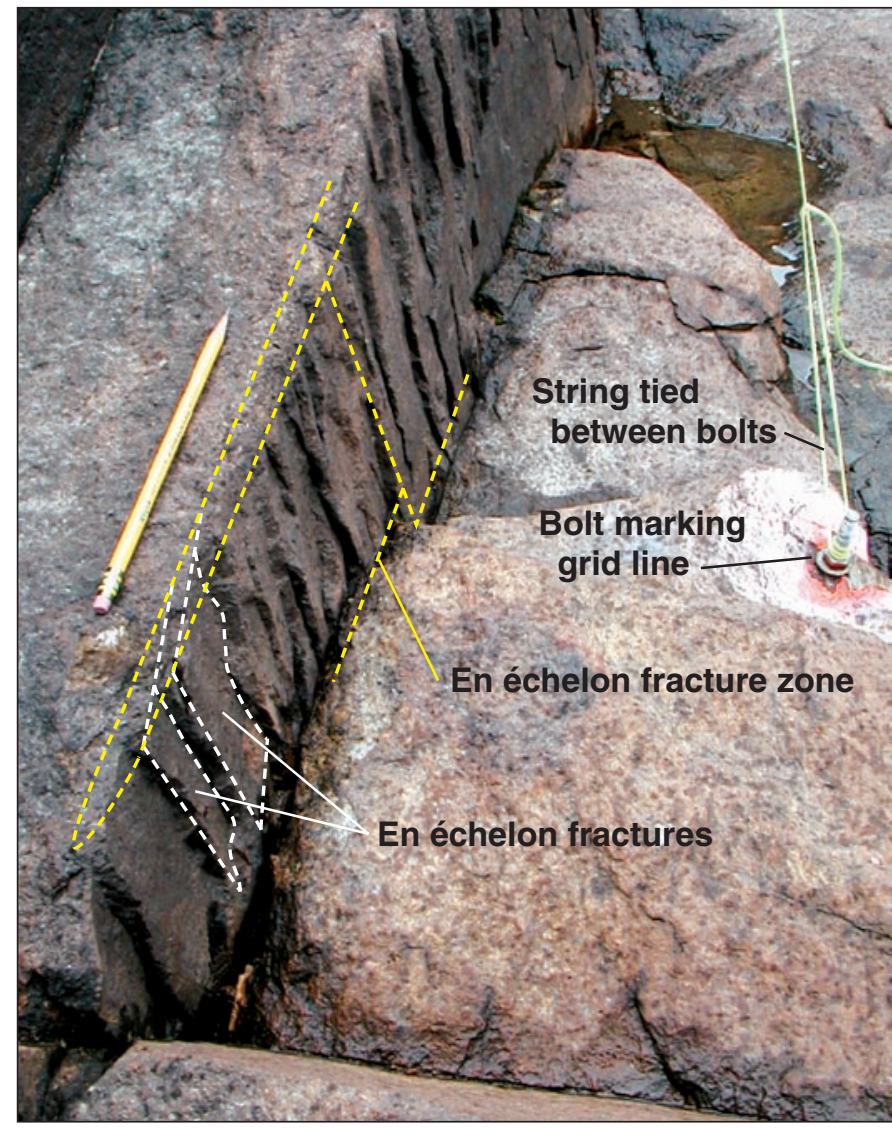

Figure 11. Outcrop with en échelon fractures in an en échelon fracture zone, cell-house site, Berlin, N.H. Map view with south at top in grid cell A20 (plate 1). (Scale shown by pencil on the left.)

(fig. 10). Billings and Billings (1975) describe similar brecciation and silicification associated with faults in the Berlin region.

\section{Fracture Trends}

Fractures measured in each 10 - by 10 -ft grid cell (plate 1) were grouped together and the principal peaks for steeply dipping fractures were determined for each grid cell (fig. 15). For comparison with the regional assessment, the grid-cell principal trends were grouped into NW, NNW, NNE, and ENE directions based on breaks observed in the Berlin area and riverbank data sets. A cluster of ENE trends in the northern part of the cell-house site, and smaller clusters of ENE trends in other parts of the site are illustrated on the diagrams shown in figure 15. Cells with NW and NNE trends are uniformly distributed across the site, and cells with NNW trends are sparsely distributed. These findings support the concept that the cell-house site is in an area of regionally overlapping fracture domains because all trends observed in the regional assessment are present at the riverbank. Principal fracture trends oriented NNE, however, appear to be restricted to the cell-house site and outcrops to the north of the site, indicating that this trend does not extend across the region (figs. 4, 15).

The principal peak of all steeply dipping fractures at the riverbank is $035^{\circ} \pm 6^{\circ}$, parallel to the Androscoggin River (fig. 16A) and the average dip is northwest (fig. 16C). The average orientation of gently dipping fractures is $\mathrm{N} .043^{\circ} \mathrm{E}$. with a dip of $9^{\circ} \mathrm{SE}$ (fig. 16B).

Fracture-intersection lineation is a brittle feature formed by the intersection of two fracture planes. Fracture lineations are prevalent in the gneiss and commonly plunge steeply

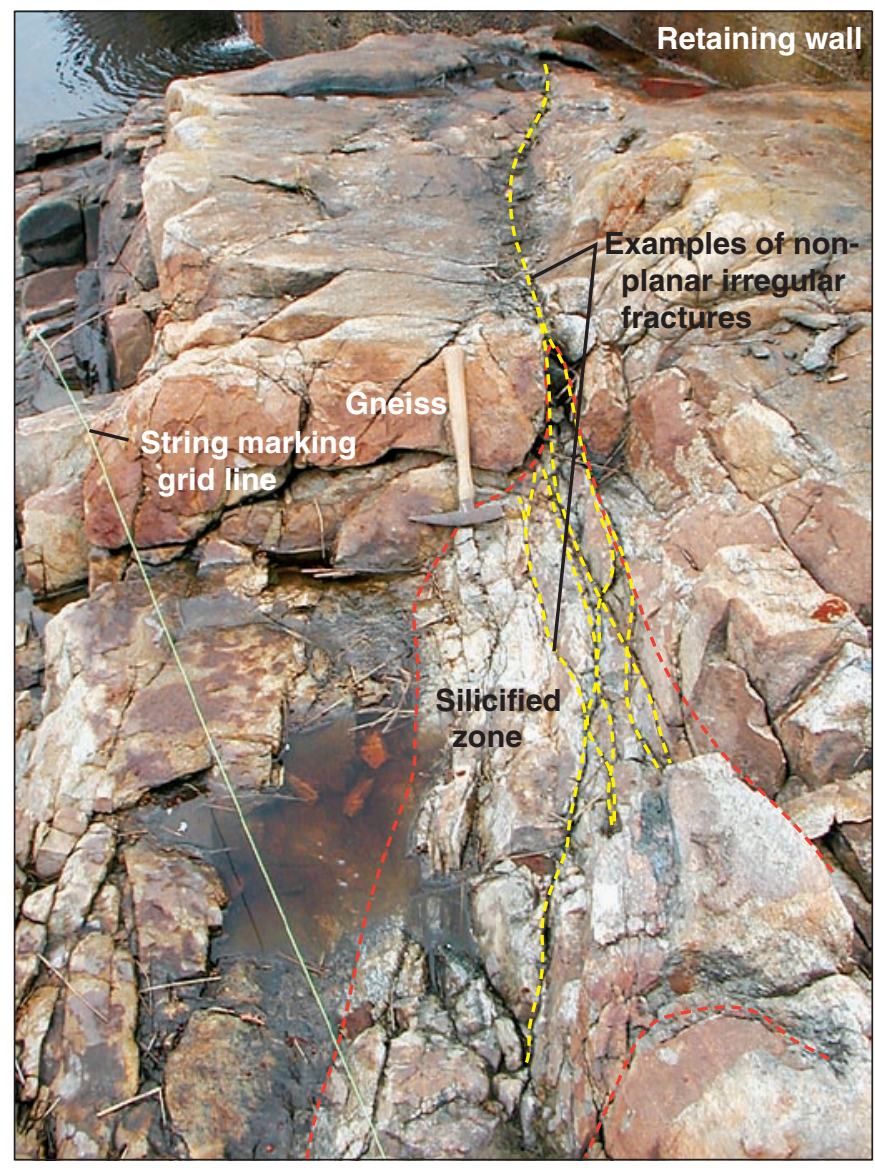

Figure 12. Outcrop of silicified fracture zone (boundary shown by red dashed line) and nonplanar irregular fractures and gneiss, cell-house site, Berlin, N.H. View to northeast, in grid cell A22 (plate 1). (Scale shown by hammer near center of photograph.) 


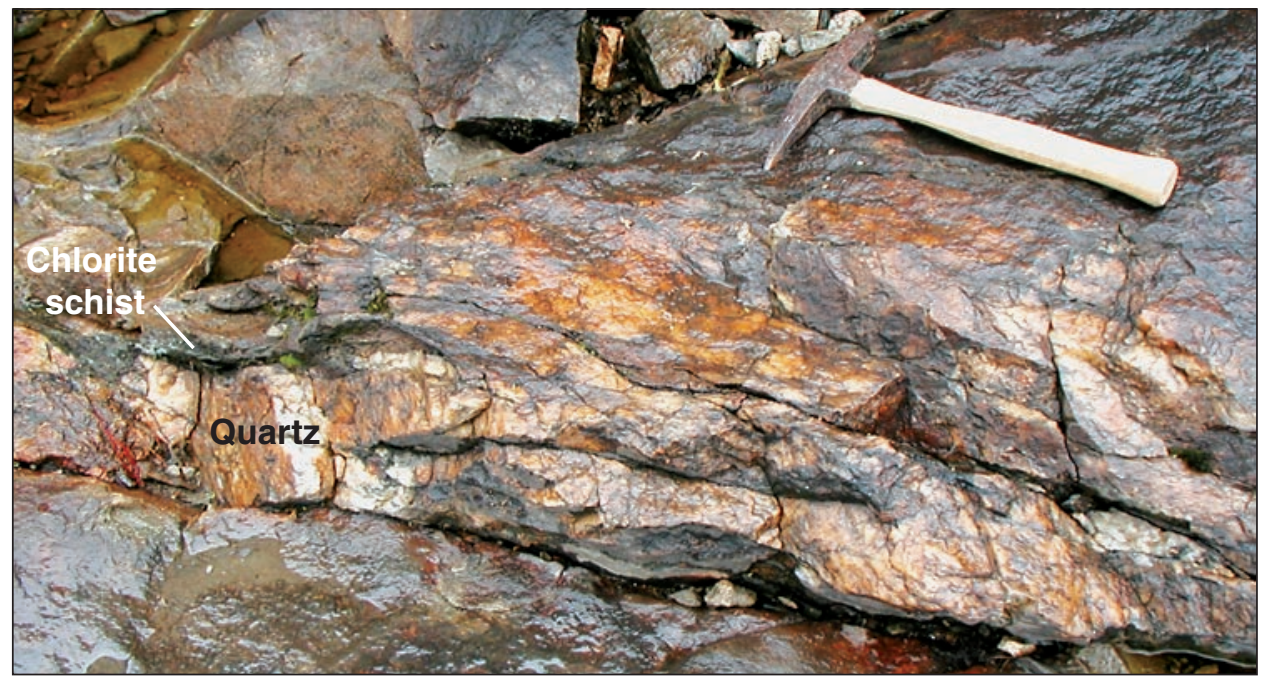

Figure 13. Outcrop with multiply sheared quartz containing interleaved chlorite schist, cellhouse site, Berlin, N.H. From grid cell B31 (plate 1). (Scale shown by hammer.)

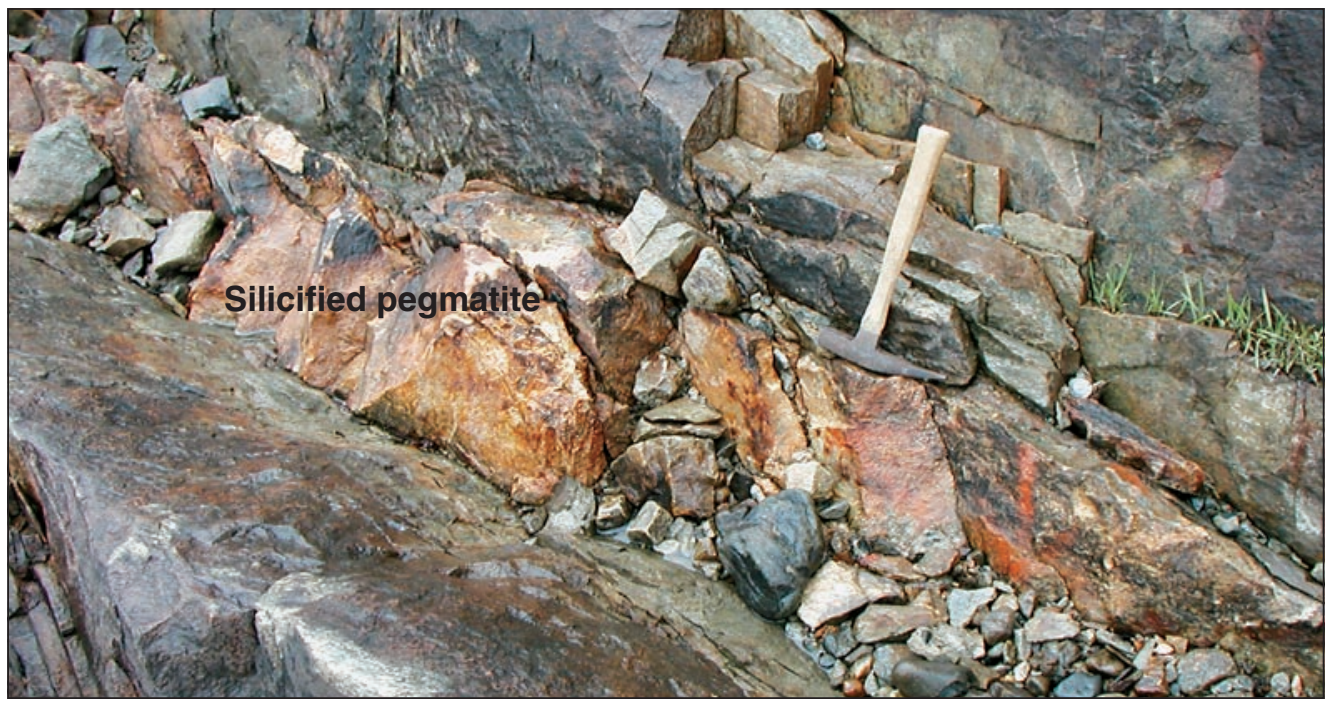

Figure 14. Outcrop with fault-bounded silicified pegmatite, cell-house site, Berlin, N.H. From grid cell B28 (plate 1). (Scale shown by hammer.) 


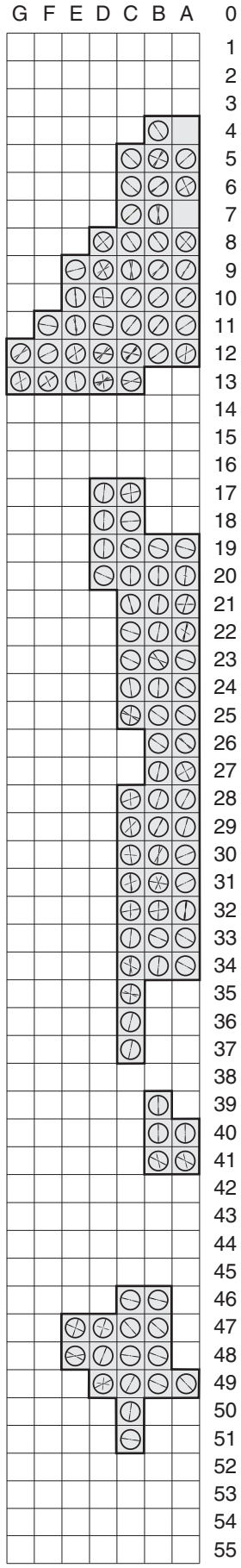

All data
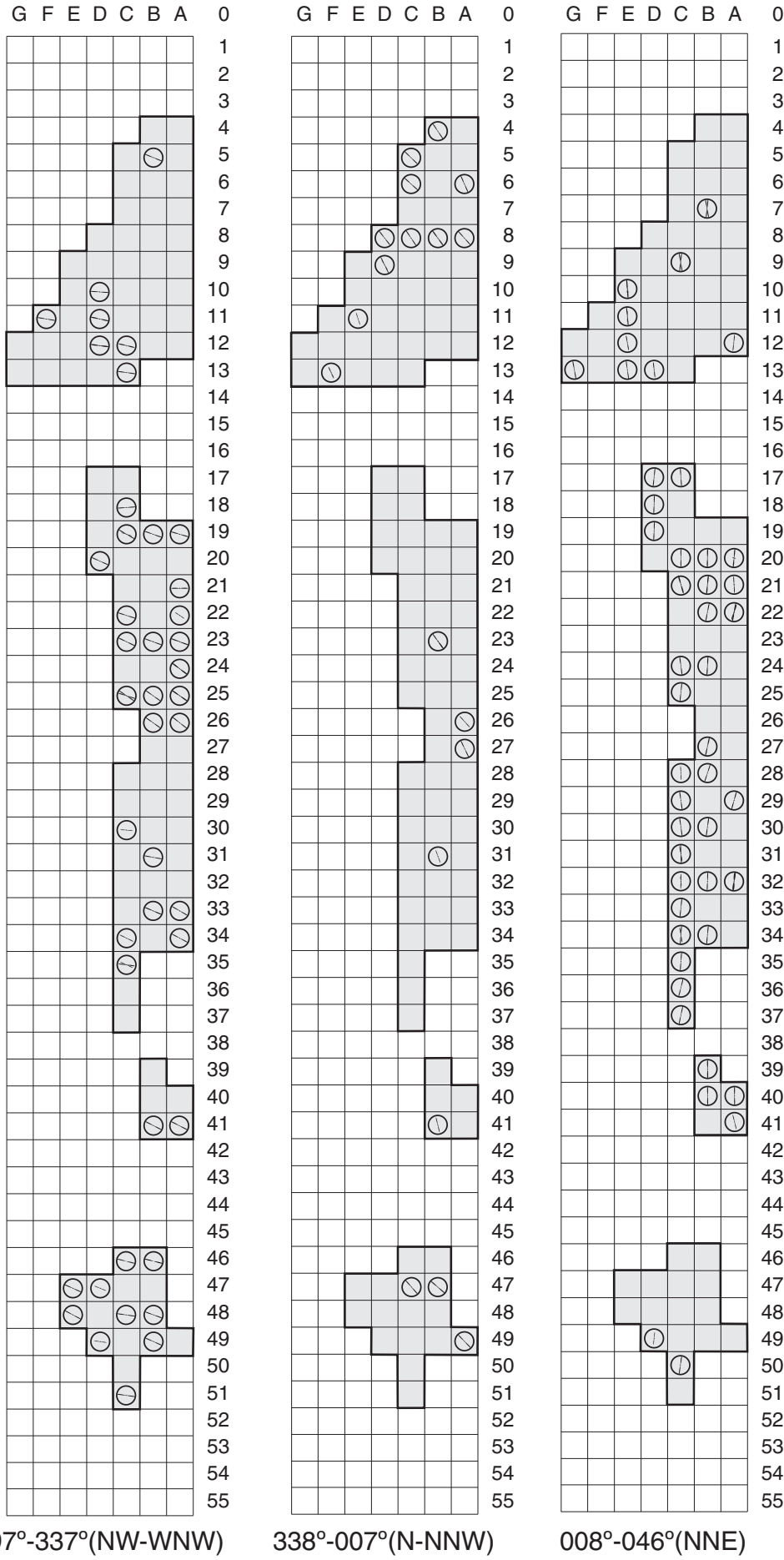

Boundary within grid (plate 1) shows analyzed outcrop area Grid oriented 30 degrees east of north Mapped at the scale of 1 inch equals 10 feet

$\ominus$ Normalized azimuth-frequency plots for all brittle structures with dips equal to or greater than 60 degrees

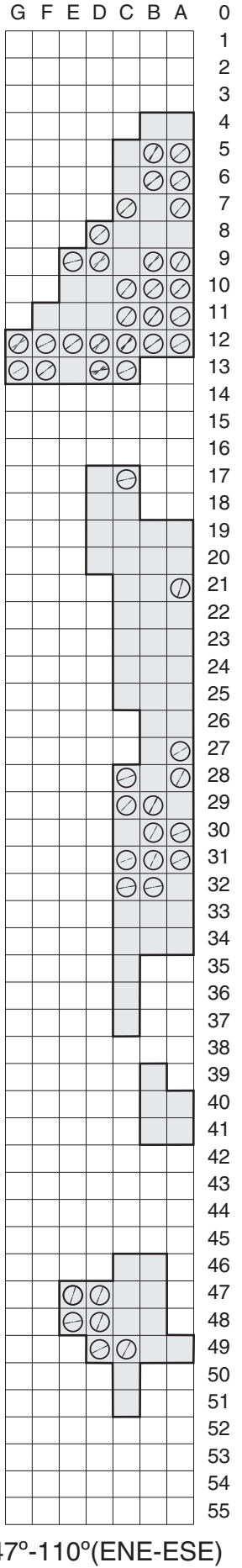

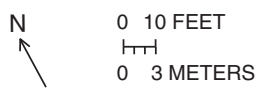

Figure 15. Cell-by-cell analysis of principal fracture trends at the cell-house site, Berlin, N.H. Grid shown on plate 1. 
$\left(80-90^{\circ}\right)$ to the northeast (fig. 17). Locally, some fracture intersection lineations plunge southwest. Fracture-intersection lineations may provide a means of vertical ground-water flow. Calculated fracture lineations were plotted for three areas, the northern, north-central, and south-central regions of the site (fig. 17). The predominant bearing and plunge of lineations are $302^{\circ}, 78^{\circ}$ in the north; $338^{\circ}, 82^{\circ}$ and $022^{\circ}, 51^{\circ}$ in the north-central; and $032^{\circ}, 33^{\circ}$ and $245^{\circ}, 54^{\circ}$ in the south-central regions of the site (fig. 17).

\section{Geologic Summary}

The rock types at the cell-house site are predominantly gneiss with lesser amounts of chlorite schist or pegmatite; a generalized section of the cell-house site geology is shown in figure 18. The chlorite schist and pegmatite tend to form nearly horizontal, or shallow east to northeast dipping, discontinuous lenses or bodies. The gneiss generally contains steeply dipping north-northeast trending, parallel fractures that tend to terminate on chlorite-schist lenses that form a folded structure plunging an average of $26^{\circ}$ in a $037^{\circ}$ direction (fig. 8B). Nonplanar fractures associated with chlorite schist lenses at the middle of the riverbank outcrop (near grid-cell B25) and to the south planar parallel fracture zones (towards grid-cell B39) are where some of the elemental mercury has been found.

Notable brittle structures include fractured chlorite-schist lenses; en échelon fracture zones, generally with 1-2 mm (0.04-0.08 in.) apertures; parallel joint zones, with apertures less than $1 \mathrm{~mm}$ (0.04 in.); and faults. The northern third of the riverbank outcrop, rows 4-14 (plate 1), contain east-northeast to east-southeast trending folded chlorite schist and planar fracture zones. North-to northeast-trending planar fracture zones intersect east-trending structures in cells E11, E12, and E13 (plate 1). A major zone of chlorite schist crosses grid-cells C6, C7, D7, and D8 (plate 1). An unfractured, approximately horizontal tabular body of pegmatite is located in grid-rows 5-10. Steeply dipping parallel fractures terminate against gently dipping tabular pegmatite.

Grid-cells B20 and B21 are underlain by very finegrained gneiss containing three, roughly orthogonal sets of parallel fractures. The topographic high in the center of the outcrop (fig. 18) contains regular sets of northwest-trending fractures in contrast to the bedrock riverbed that contains north to northeast-trending fracture sets. The orthogonal pattern in cell B21 results from northwest-trending fractures in the high area intersecting the north and northeast sets of the riverbed. Grid-cell B21 exposes rocks at an elevation where the two sets meet. This area, the only area with such regular spacing of fractures, is also the only large area of fine-grained gneiss.

The western and southern part of the outcrop, on a horizontal ledge below the cliff face in grid-cell C23 (fig. 18) contains a zone of folded chlorite schist (plate 1). A series of north-northeast plunging asymmetric folds with counter-clockwise rotation sense deforms this 5 -to 50 -cm-thick (2 to 20-in.) zone. The deformed chlorite schist is characterized by vugs

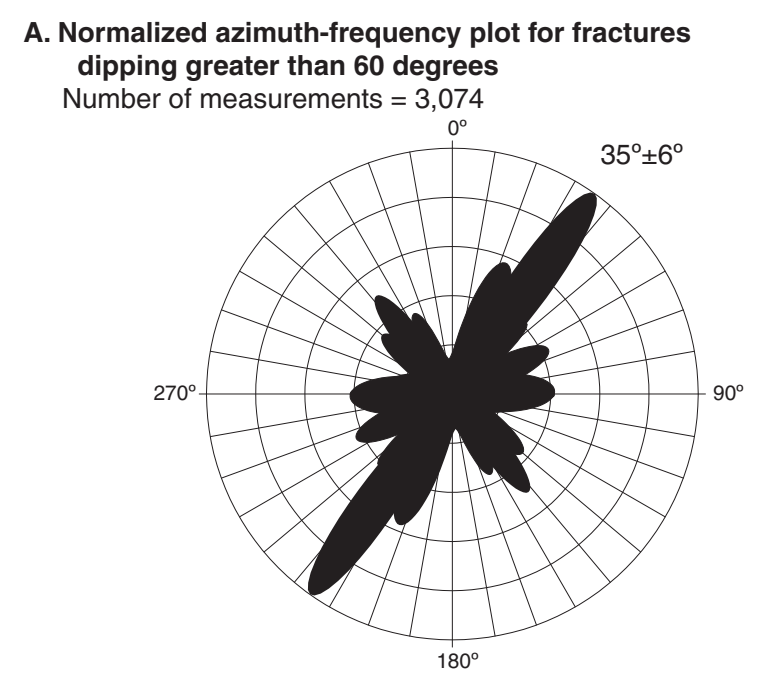

B. Stereonet for fractures dipping less than 60 degrees Contour interval 2 percent Maximum point at 9 percent

Number of measurements $=411$

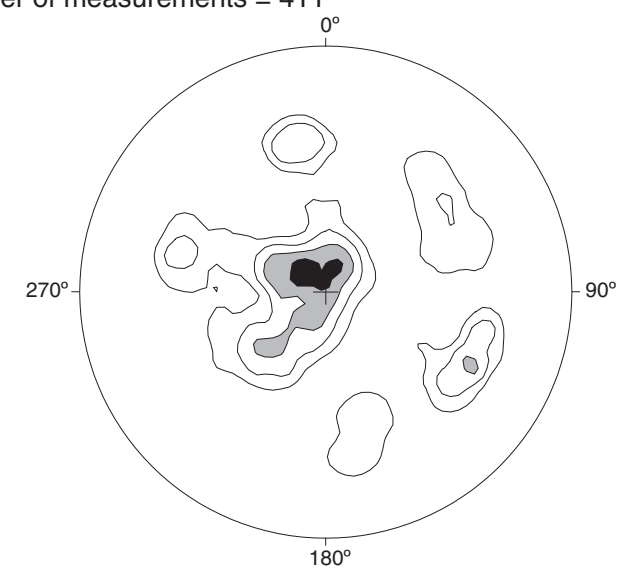

C. Stereonet of all fractures

Contour interval 1 percent

Maximum point at 12 percent

Number of measurements $=3,485$

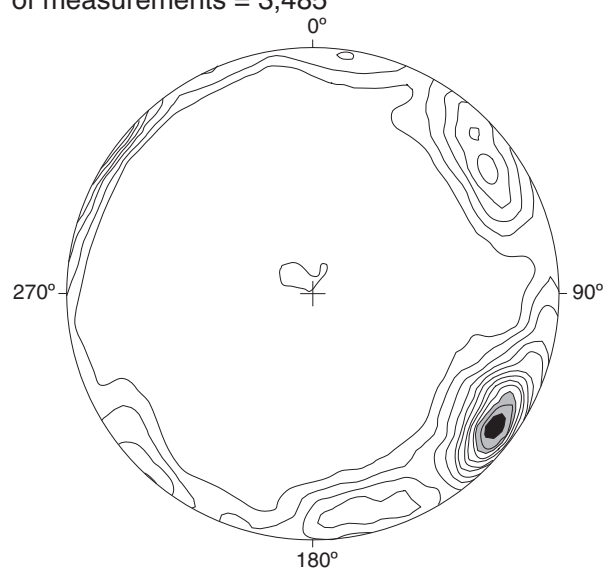

Figure 16. Orientation of all fractures at the cell-house site, Berlin, N.H. (A) normalized azimuth-frequency plot for steeply dipping fractures, (B) stereonet for fractures dipping less than $60^{\circ}$, and $(C)$ stereonet of all fractures. 

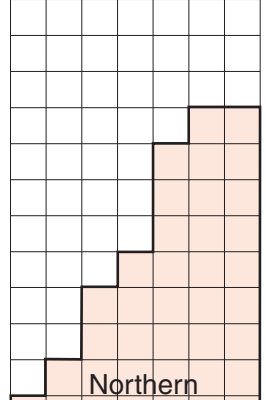

region

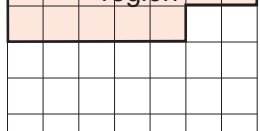

\begin{tabular}{|l|l|l|l|l|l|}
\hline & & & & & 16 \\
\hline
\end{tabular}
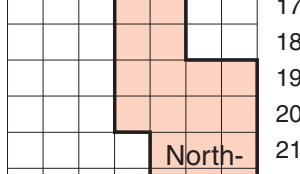

central 22

region 23
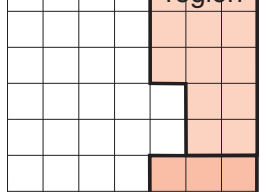

South-

central 30

region 31
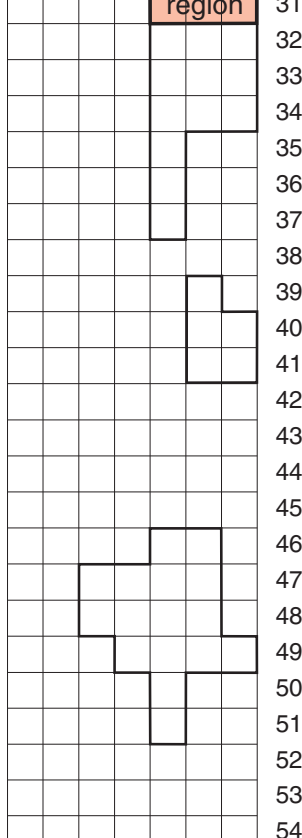

53
54
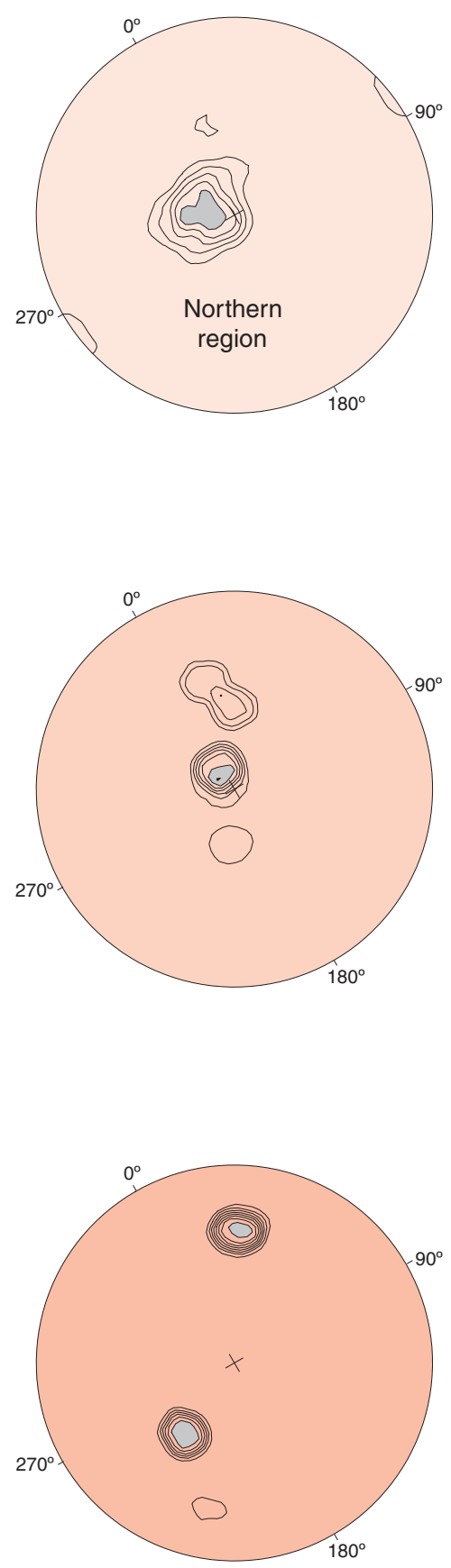

(ineations, rows 10 - 13; number of measurements $=1,805$ intersections; contour interval 6 percent; predominant bearing and plunge are $302^{\circ}, 78^{\circ}$

Fracture-intersection lineations, rows 17 - 27; number of measurements $=764$ intersections; contour interval 6 percent; predominant bearing and plunge are $338^{\circ}, 82^{\circ}$ and $022^{\circ}, 51^{\circ}$

Fracture-intersection lineations, rows 28 - 31; number of measurements $=268$ intersections; contour interval 6 percent; predominant bearing and plunge are $032^{\circ}, 33^{\circ}$ and $245^{\circ}, 54^{\circ}$

Figure 17. Stereonet plots of fracture-intersection lineations for the northern, north-central, and south-central regions of the riverbank at the cell-house site, Berlin, N.H. Grid shown on plate 1. 
and is folded and rodded such that secondary porosity may be produced in the plane of the schist. Five, 10-cm-thick (4-in.) folded chlorite-schist lenses (plate 1), exposed on horizontal and vertical outcrop surfaces, are stacked on top of each other in grid-cells A26 and B26 through B28. On the outcrop face in this area, fold axes, crenulations, and rods plunge east-northeast.

Two chlorite-mineralized brittle faults that are not folded trend to the south from B26 (plate 1). A silicified pegmatite lies between these brittle faults and abuts folded chlorite schist in grid-cells B26 through B28. The silicified zone (fig. 12) continues to grid-cell B34. Sets of parallel fractures (plate 1, fig. 18), lie to the west and strike parallel to the river from $\mathrm{C} 30$ to $\mathrm{C} 37$.

\section{Results of Hydrogeologic Analyses}

Geologic, geophysical, and hydrologic surveys and data were integrated to characterize the hydrogeology of the cellhouse site. The combined analysis of geologic data, geophysical surveys, and hydrologic data allows interpretation of data that might otherwise be ambiguous. The hydrogeology of the site as a whole is provided in the analysis of ground- and surface-water levels, head gradients, and bulk hydraulic connectivity between the river and individual wells. Selected areas were characterized in greater detail to identify anomalous areas of the bedrock for further investigation.

\section{Analysis of Surface and Ground-Water Levels}

Surface- and ground-water levels are used to assess hydraulic connections and provide a hydraulic analysis of the bedrock-river aquifer system. The location of the canal; the Androscoggin River; remedial modifications (barrier wall and cap); and relic foundations and plumbing, including the concrete retaining wall and discharge pipe, affect spatial and temporal variability in water-level fluctuations and flow patterns at the site.

\section{Head Surfaces and Hydraulic Connections}

A hydraulic head map constructed from overburden water levels on March 20, 2003 (fig. 19A), represents generally low water-level conditions and indicates a head difference of about $5 \mathrm{ft}$ across the site. An unsaturated zone in the middle of the capped area (dry area on fig. 19A), caused by a high bedrock surface, separates flow in the overburden into a northern and southern area. The flow is to the west toward the river in both the northern and southern areas. A hydraulic-head map constructed from water levels on April 2, 2003 (fig. 19B), indicates a high water-level condition with a head gradient similar to the low water-level condition on March 20, 2003. Because overburden water-level fluctuations are small, head gradients in the overburden remain fairly constant across the cap area partly the result of the relatively stable head in the canal, and flow out of the discharge pipe in the concrete wall, in addition to the geomembrane cap on the site. The discharge pipe drains

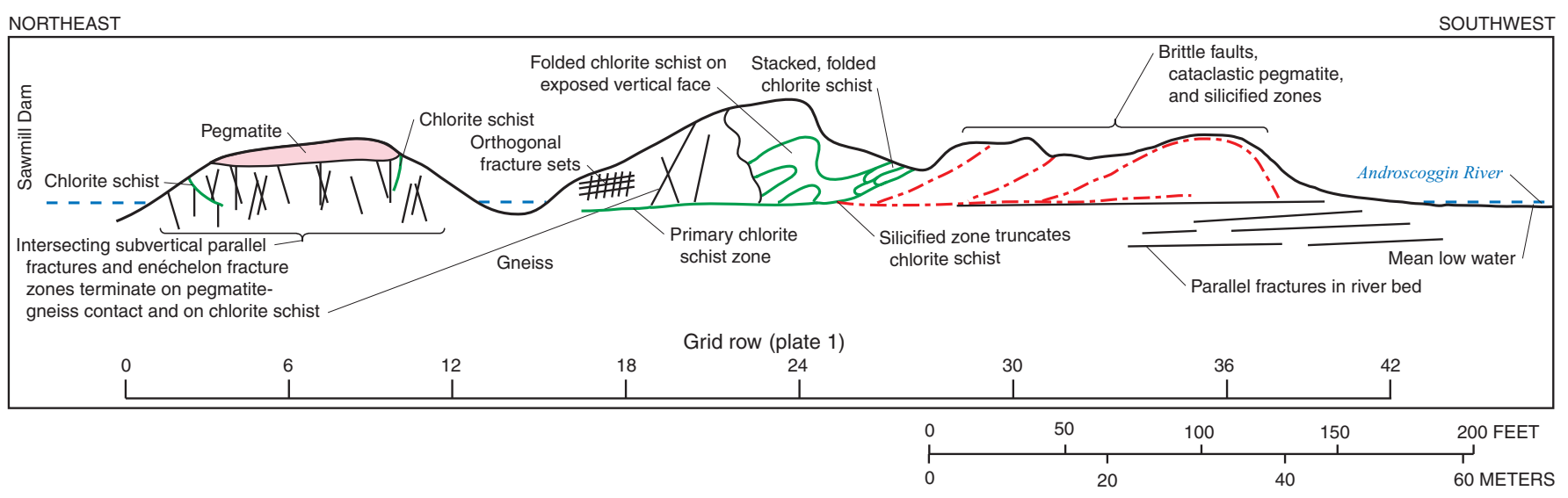

Figure 18. Generalized cross section of the bedrock geology at the cell-house site outcrop from grid 0 to 36 , (360 feet) looking east, Berlin, N.H. Location shown on plate 1. 


\section{Overburden}

A. Low water-level conditions, March 20, 2003

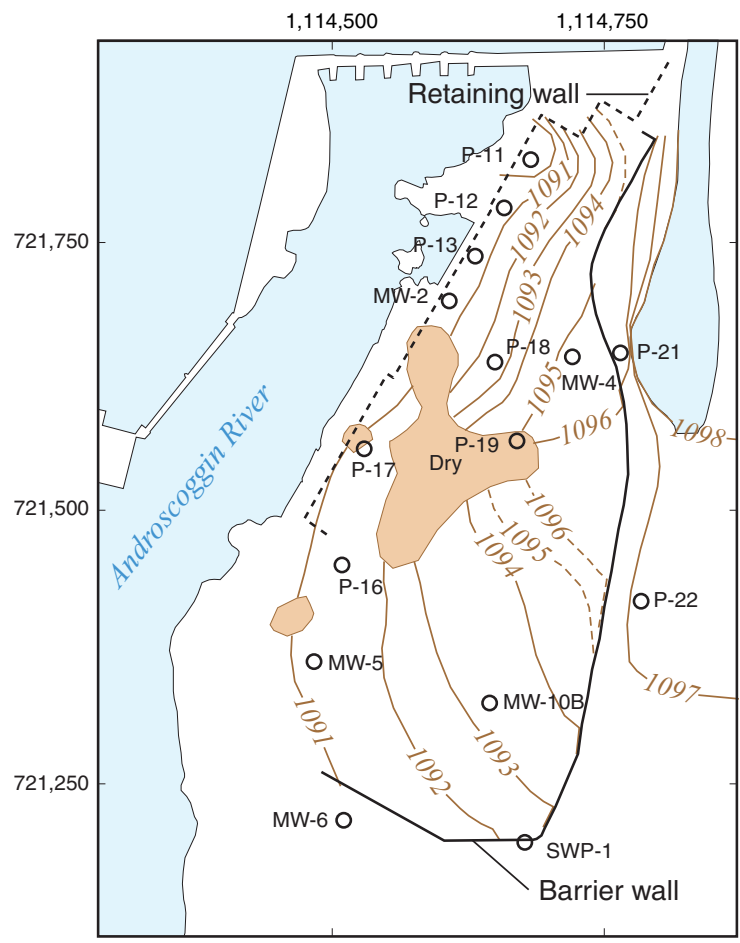

Barrier wall from Weston Solutions, Inc.; Sawmill Dam and hydrography from Nexfor Fraser Papers, Berlin-Gorham Operations: New Hampshire state plane feet coordinate system, NAD 83
B. High water-level conditions, April 2, 2003

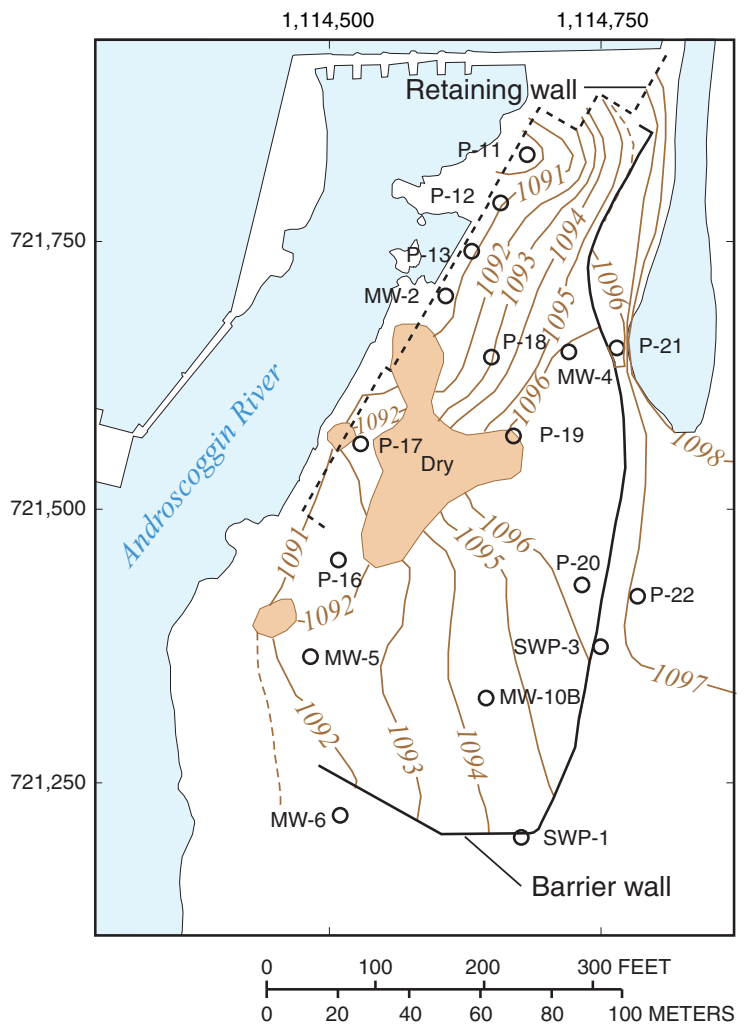

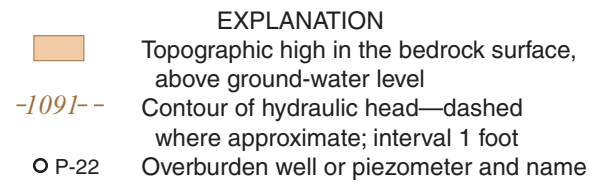

Figure 19. Hydraulic-potentiometric-head surface of (A) low (March 20, 2003) and (B) high (April 2, 2003) water-level conditions in overburden at the cell-house site, Berlin, N.H.

water at the base of the overburden near the river towards an altitude of 1,087.4 ft above NAVD 88 (the altitude of the base of the pipe).

The geometry of the overburden and the bedrock surface is also a control on overburden hydraulic-head elevations. The overburden is in contact with the canal, a nearly constant head, but is not in contact with the Androscoggin River downstream of the dam. Ground water flows laterally (westerly) in the overburden from the canal, downgradient along the bedrock surface, to the Androscoggin River (fig. 19). The alternating lenses of pegmatite, chlorite schist, and gneiss in the underlying bedrock may impose a vertical anisotropy so that the saturated overburden is perched above unsaturated bedrock adjacent to the river. Overburden head measurements and interpreted contours indicate a flow divide on the southwestern side of the canal area for the March and April dates (figs. 19A, B). Ground water north of the divide flows northwesterly, south of the divide it flows southwesterly. Ground water on the north side must either flow through the leaks in the retaining wall or into bedrock to discharge toward the river.

Bedrock water levels measured on March 20, 2003

(fig. 20A), during low water-level conditions, indicate a large head difference (about $14 \mathrm{ft}$ ) across the site. The difference is $8 \mathrm{ft}$ greater than the overburden gradient for the same period (fig. 19A). Head contours indicate a northwesterly bedrock ground-water-flow direction for much of the cap area and a westerly flow direction for the southern part of the cap area. Bedrock water levels measured on April 2, 2003 (fig. 20B), 


\section{Bedrock}

A. Low water-level conditions, March 20, 2003

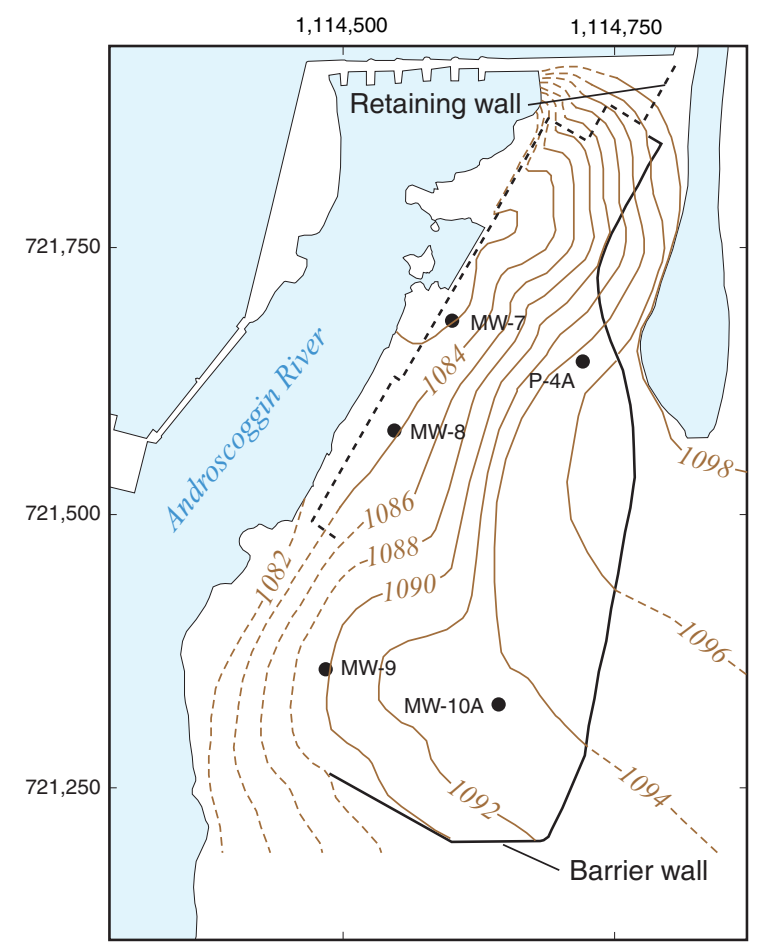

Barrier wall from Weston Solutions, Inc.; Sawmill Dam and hydrography from Nexfor Fraser Papers, Berlin-Gorham Operations; New Hampshire state plane feet coordinate system, NAD 83
B. High water-level conditions, April 2, 2003

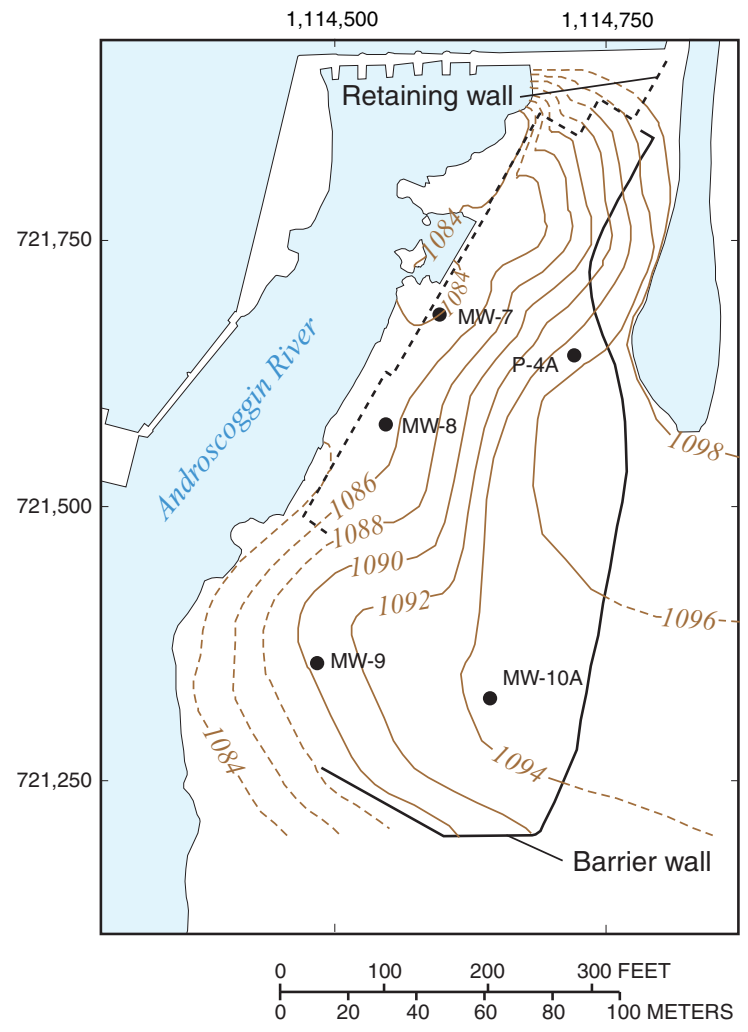

EXPLANATION

-1092- - Contour of hydraulic headdashed where approximate; interval 2 feet

- MW-9 Bedrock well and name

Figure 20. Hydraulic-potentiometric-head surface of (A) low (March 20, 2003) and (B) high (April 2, 2003) water-level conditions in bedrock at the cell-house site, Berlin, N.H.

for high water levels indicate a head gradient (about $13 \mathrm{ft}$ ), slightly less than gradients under low water levels. Whereas the canal water levels are relatively stable (fluctuate less than $1 \mathrm{ft}$ ), river water levels rose by about $2.5 \mathrm{ft}$ from March to April, resulting in a smaller April gradient than in March. Maximum head gradients in the bedrock are more likely to result during low river stages. Head contours in April, when the river stage is high, indicate the potential for flow reversals from the river into the bedrock aquifer.

Calculated bedrock head gradients show small variations in maximum azimuthal direction but large variations in the slope of the gradient. Bedrock head-gradient directions for March 20, 2003, and April 2, 2003, were similar, 308 and $307^{\circ}$ respectively, whereas the corresponding gradients differed (0.0312 ft/ft and $0.0303 \mathrm{ft} / \mathrm{ft}$, respectively). During a later high water-level period (October 31, 2003, table 2), the azimuthal head gradient was slightly different $\left(302^{\circ}\right)$ while the gradient was less $(0.0257 \mathrm{ft} / \mathrm{ft})$ than during other high periods. From the 2002-03 data, variations in gradient direction are small during different hydrologic conditions, less than $6^{\circ}$, but variations in the gradient slope were up to 12 percent. The direction of the bedrock head gradient shifts further downstream as river stage rises. This shift also indicates that the river and bedrock are closely connected hydraulically.

Water-level data from overburden and bedrock wells in the capped area indicate a combination of upward and downward gradients on April 2, 2003 (table 2). Upward gradients from the fractured bedrock to the overburden could provide ground-water recharge to the overburden. 
Water-level fluctuations and maximum and minimum water levels vary spatially and temporally. Water levels in overburden wells near the canal (P-21, MW-4, fig. 21) fluctuate more (about $2 \mathrm{ft}$ ) than overburden wells adjacent to the Androscoggin River but less than water levels in the bedrock wells. Water-level fluctuations were the least (less than $2 \mathrm{ft}$ ) in overburden wells adjacent to the Androscoggin River (P-11, $\mathrm{P}-12$ ) and greatest from (2 to more than $4 \mathrm{ft}$ ) in bedrock wells at the same location (MW-7, MW-8, fig. 22). Maximum nor minimum water levels did not occur on the same dates; therefore, measured periodic water levels for each well were ranked (table 3 ) to select the optimum high and low water period for contouring the potentiometric-head surface. Most wells had high water levels on October 31, 2003, and April 2, 2003. However, on April 2, 2003, some wells also had relatively low water levels (table 3). Low water levels were generally measured on March 20, 2003, but also on June 3, June 25, July 16, and August 20, 2003.

Ground-water-level fluctuations measured at continuous sites (table 4) fluctuated most at bedrock well MW-7, and least at overburden well MW-2 (located $10 \mathrm{ft}$ south of MW-7) for the period of record. The average vertical head gradient between the overburden and bedrock (at MW-2 and MW-7, fig. 2) is large (more than $8 \mathrm{ft}$ ) and indicates a poor vertical connection between the overburden and bedrock near the riverbank (fig. 2).

Daily precipitation ${ }^{1}$ caused only small water-level rises in overburden wells MW-5 and MW-4, which indicates that there is little infiltration (recharge) through the site cap (fig. 21). No water-level rises from daily precipitation were measured for well MW-2. The rise in water levels around April 1, 2003, represents recharges from snowmelt either through or under the barrier wall. Water levels in MW-4, (inside the barrier) and P21 (outside the barrier) show similar fluctuations although the response of water levels to daily precipitation is greater at well
P-21 than well MW-4. This result indicates that either reduced recharge rates inside the barrier from the land cap and(or) water levels are affected from lateral flow under or through the barrier from ground water outside the barrier. Rises in water levels at MW-4 lag about 1 hour behind rises at P-21 based on instantaneous 15-minute readings. Inside the capped area, well MW-5 (fig. 21), shows a delayed response to precipitation events indicating that recharge likely occurs laterally and not directly from precipitation.

Water levels at MW-2 are likely controlled by the elevation of the bedrock surface and the discharge of water from the pipe in the concrete retaining wall. Leakage from the overburden to the underlying bedrock is low; the overburden materials are saturated, whereas the upper bedrock near the river is unsaturated. On August 20, 2003, discharge from the 10.5-in. inner-diameter discharge pipe through the retaining wall was estimated to be approximately $0.03 \mathrm{ft}^{3} / \mathrm{s}(13 \mathrm{gal} / \mathrm{min})$ based on equations for flow in a non-vertical pipe (McDonald, 1950). On October 31, 2003, no flow was observed from the pipe while at other times flow rates appear to be large (more than $25 \mathrm{gal} / \mathrm{min}$ ). During winter months, flow is often reduced because ice blocks the discharge pipe.

Average daily water levels at bedrock wells near the river and the average daily stage at SW-1 in the Androscoggin River downstream of the dam (fig. 22) are closely related. Bedrock wells MW-8 and MW-7, located within $50 \mathrm{ft}$ of the river, show head fluctuations similar to the river stage. Bedrock heads are generally above the stage of the river at MW-8 indicating that ground water discharges to the river. However, for 4 of 191 days monitored in 2002 and 2003, the daily average stage at SW-1 was higher than daily average heads at MW-8 causing reversals in the gradient between the river and bedrock aquifer at this location. Heads in MW-7 are slightly lower than SW-1, for 180 of 191 days monitored in 2002 and 2003, indicating a connection to the river downstream of the pool at SW-1 (fig. 2).

Table 2. Altitudes and differences of heads in overburden and bedrock well pairs at the cell-house site, Berlin, N.H..

[--, no data, well locations are shown in figure 2]

\begin{tabular}{lcccc}
\hline $\begin{array}{c}\text { Monitoring } \\
\text { well pair } \\
\text { (overburden/rock) }\end{array}$ & $\begin{array}{c}\text { Overburden head, } \\
\text { in feet } \\
\text { April 2, 2003 }\end{array}$ & $\begin{array}{c}\text { Bedrock head, } \\
\text { in feet } \\
\text { April 2, 2003 }\end{array}$ & $\begin{array}{c}\text { Head difference overburden } \\
\text { (minus bedrock), } \\
\text { in feet }\end{array}$ & Comments \\
\hline MW-4/P-4A & $1,096.18$ & $1,095.74$ & 0.44 & Downward gradient \\
MW-2/MW-7 & $1,090.63$ & $1,084.34$ & 6.29 & Downward gradient \\
MW-3/MW-8 & Dry & $1,085.50$ & -- & Dry overburden \\
MW-5/MW-9 & $1,092.38$ & $1,090.42$ & 1.96 & Downward gradient \\
MW-10B/MW-10A & $1,094.31$ & $1,094.36$ & -.05 & Upward gradient \\
\hline
\end{tabular}

${ }^{1}$ Daily precipitation from Berlin (National Oceanic and Atmospheric Administration, 2003). 


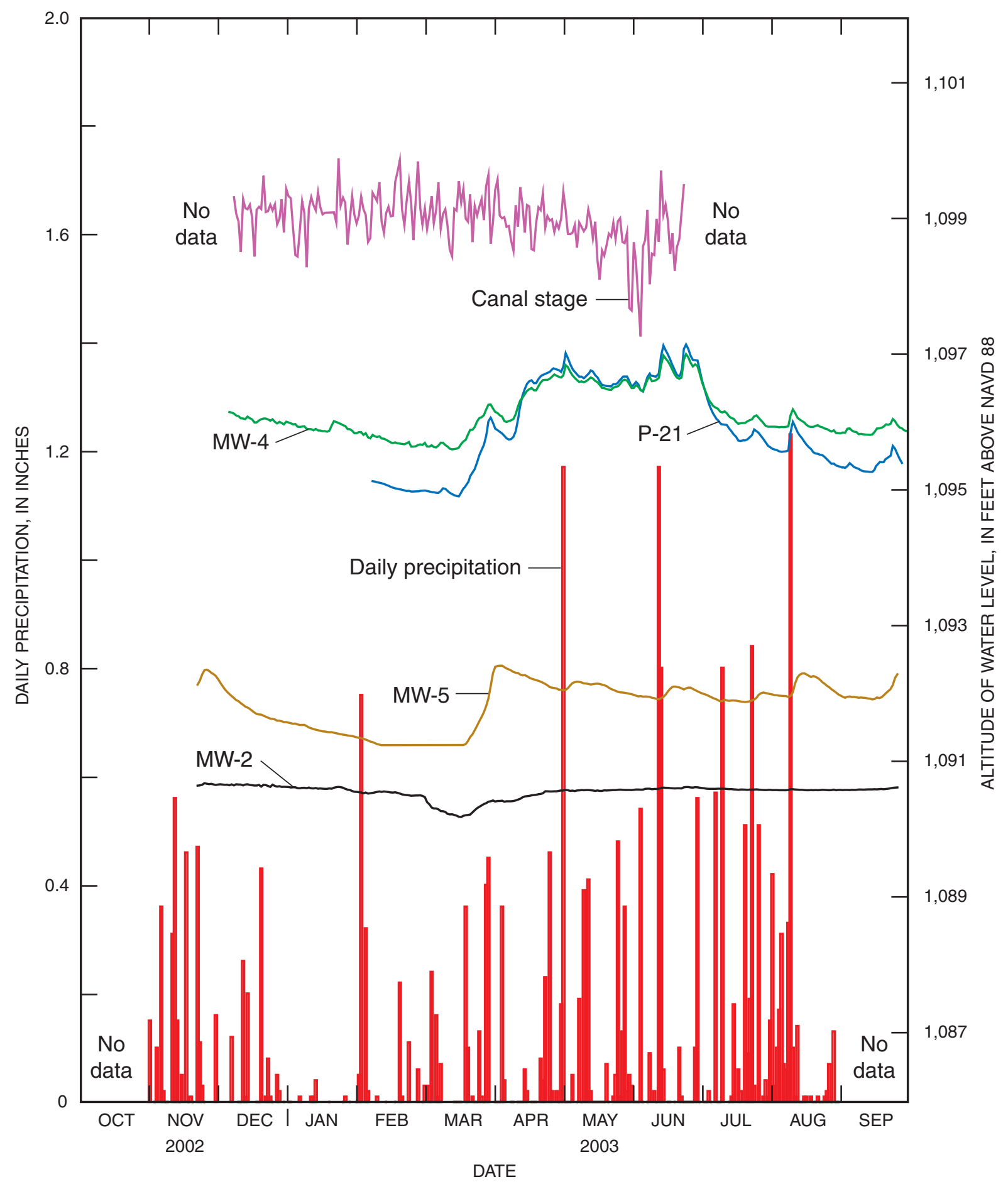

Figure 21. Daily precipitation and average daily water levels from overburden wells MW-2, MW-4, MW-5, P-21, and canal stage at the cell-house site, Berlin, N.H. (Location of wells shown on figure 2. Daily precipitation data from National Oceanic and Atmospheric Administration, 2003) 


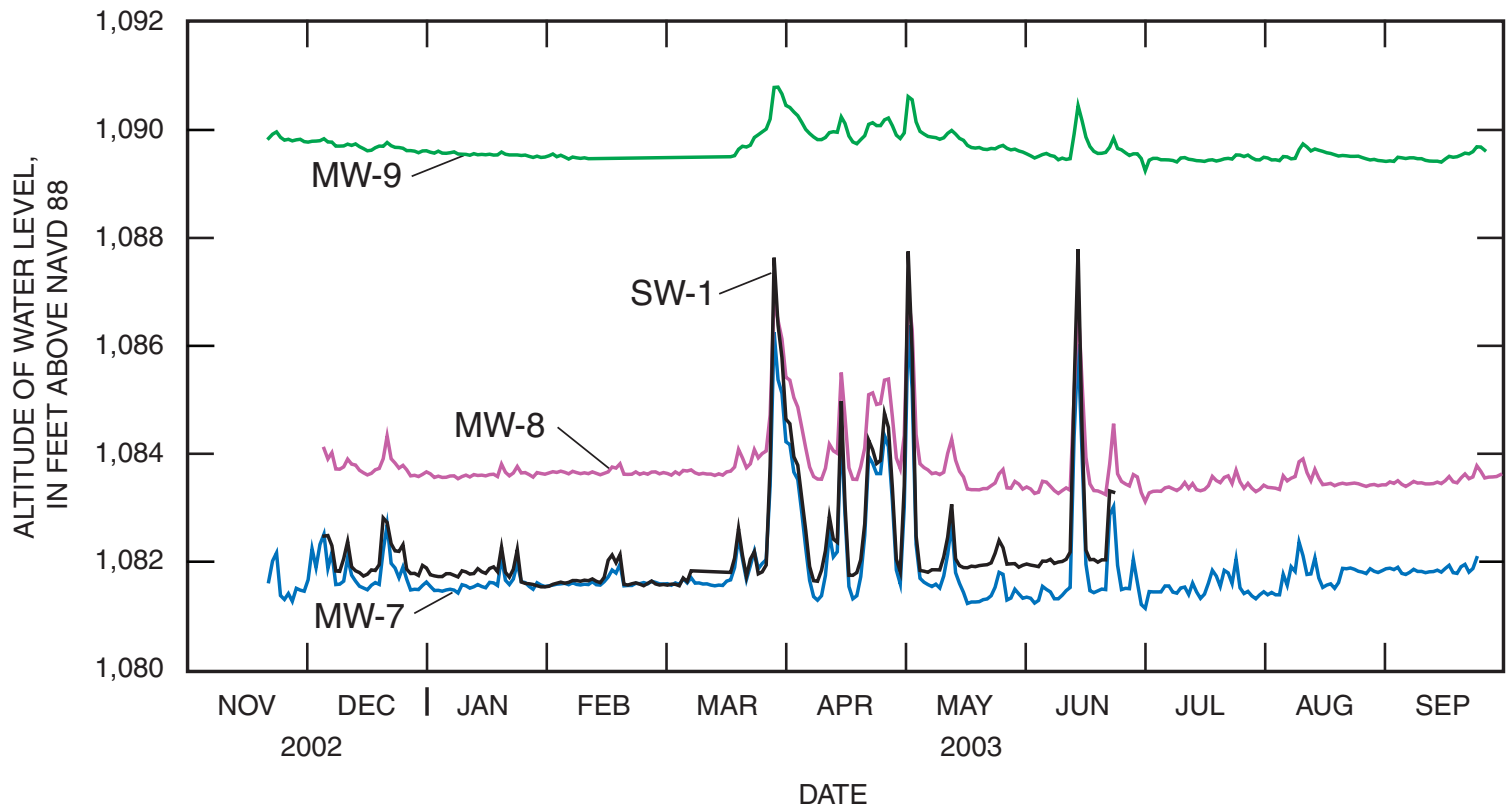

Figure 22. Average daily water levels from bedrock wells MW-7, MW-8, and MW-9 and river stage from surfacewater measuring point SW-1 at the cell-house site, Berlin, N.H. (Location of sites shown on figure 2.)

Ground-water specific conductance at MW-7 shows small variations associated with a water-level rise on June 15, 2003 (fig. 23). The specific conductance of ground water at MW-7 is high, exceeding $4,000 \mu \mathrm{mos} / \mathrm{cm}$. A general decrease in the ground-water specific conductance at MW-7, with sustained high river stage, indicates that low specific conductance river water may temporarily flow into the bedrock aquifer with the increased gradient from the river. However, river-water infiltration during the gradient increase on June 15, 2003, appears to be small at MW-7 because values of specific conductance of ground water remained high.

Average daily river-water specific conductance (fig. 24) for the period of record (December 2002-July 2003) shows a pattern of dilution with increased streamflow. Gradual rises in specific conductance during low-flow periods (fig. 24 inset) may indicate that high-conductivity ground water is seeping into the pool from the site. Flow reversals are followed by more conductive water in the pool.

Average daily ground-water specific conductance at MW-7 for the period of record (fig. 23 inset) shows small changes with variations in water level. A large increase in specific conductance occurs in early March 2003 that is unrelated to ground-water-level fluctuations.

An example of a reversal and temporary increase in head gradients between ground and surface water occurred between June 15 and 16, 2003 (figs. 22, 25), where the river stage temporarily exceeds the head at MW-8 (reversal) and the gradient measures between the river and head at is about $2 \mathrm{ft}$ greater than the head at MW-7. A corresponding surface water and ground-water-level rise occurs (figs. 22, 25) indicating that the bedrock is in direct connection with the river water. Because little precipitation fell during June 14-18, 2003, fluctuations in ground-water levels are primarily related to river-stage changes.

During the June 14-18, 2003, stage rise and subsequent decline, the specific conductance of river water shows a number of large variations with changing river water quality. A spike in specific conductance of river water occurs immediately as the river stage rises during this non-precipitation (stage controlled) period, indicating flushing of degraded runoff water from upgradient areas of the study area. A decrease in specific conductance of river water occurs from dilution after the early increase of river stage. 


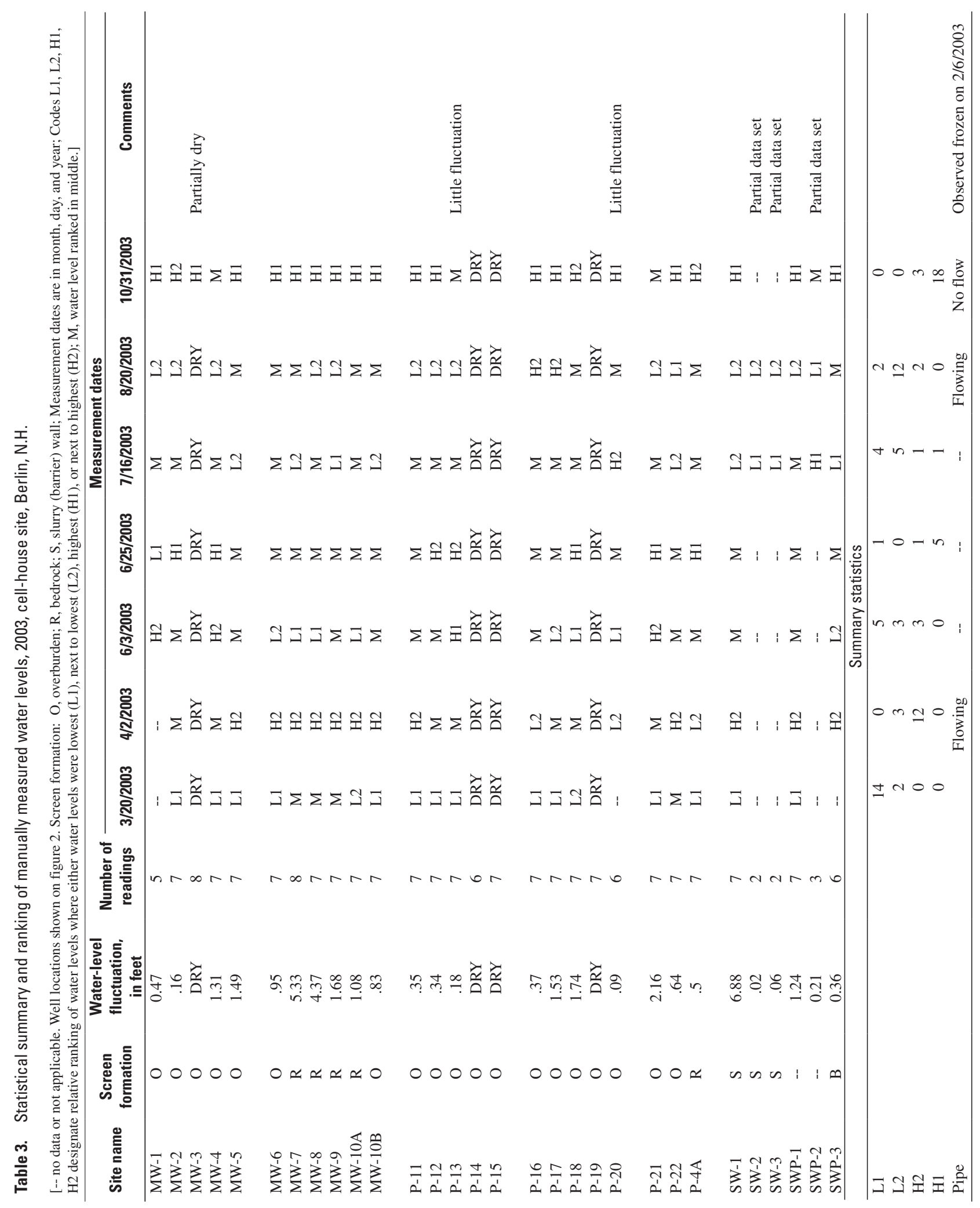




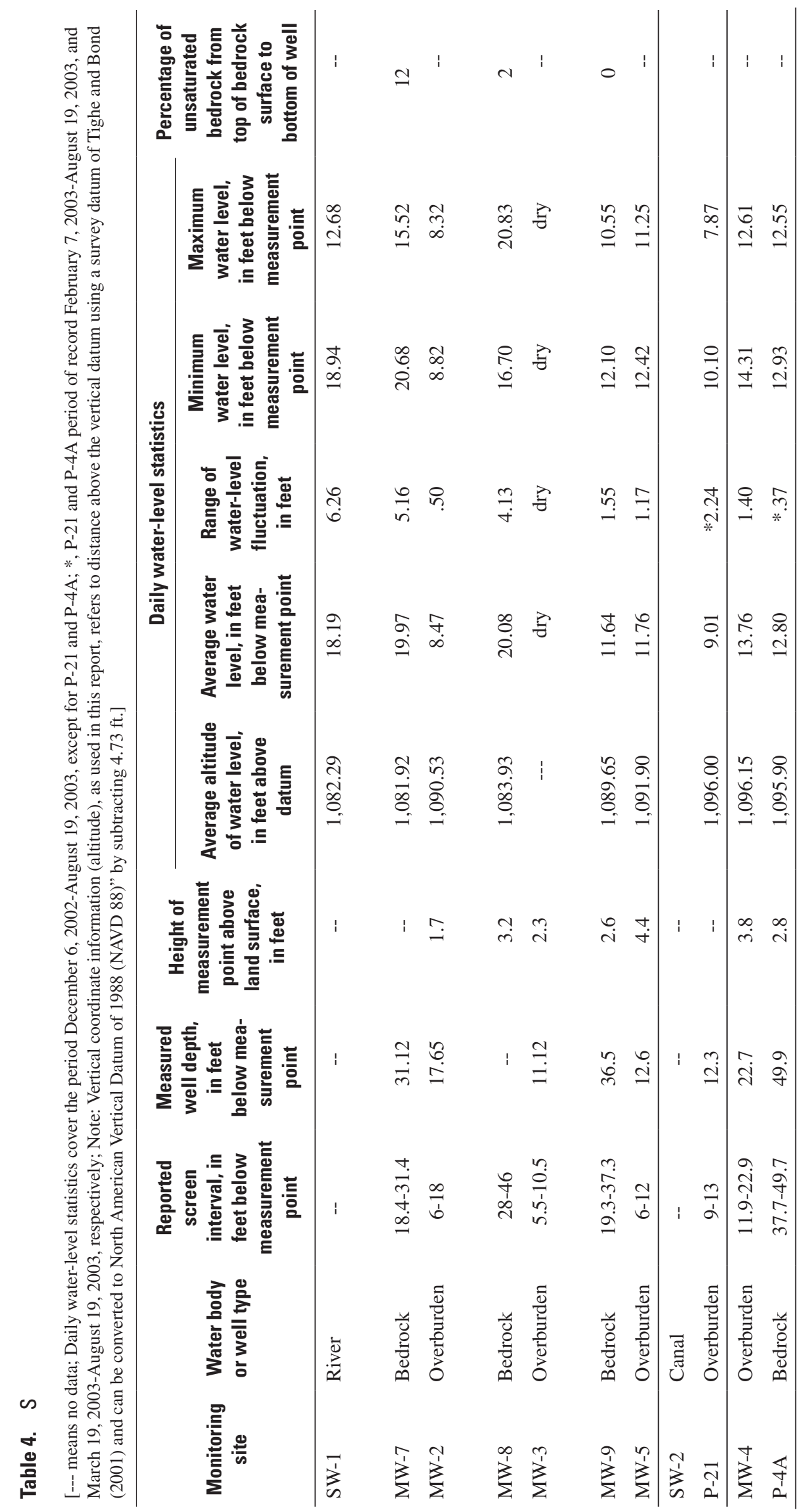




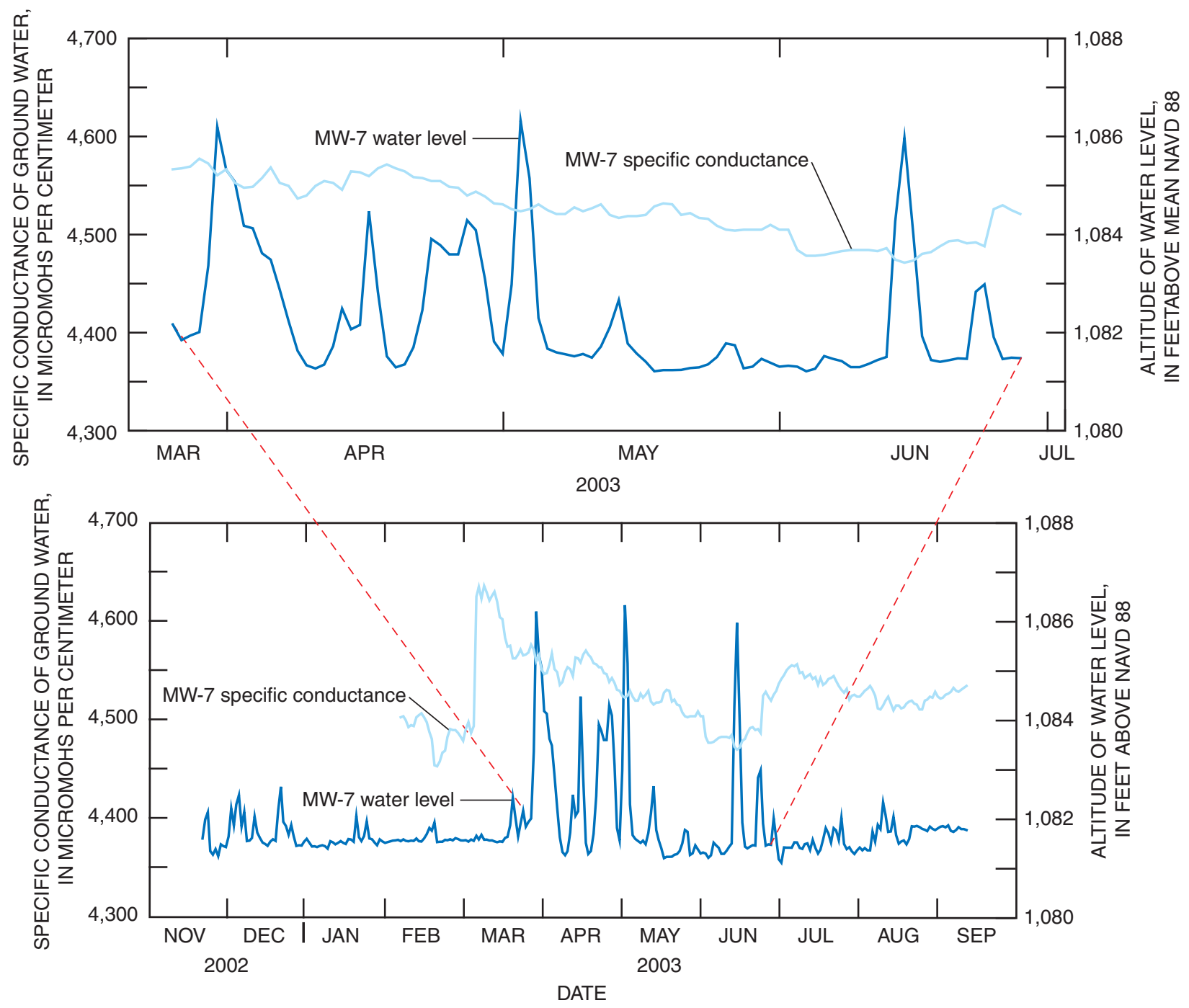

Figure 23. Average daily water levels and specific conductance at well MW-7 at the cell-house site, Berlin, N.H.

\section{Hydraulic Properties}

Water levels in the overburden adjacent to the canal, on the eastern perimeter of the site (fig. 2), are similar to the canal and indicate that these areas are hydraulically connected. The connection is subdued and is formed by ground-water leakage either through the barrier wall or through horizontal and steeply dipping fractures in bedrock beneath the wall. This hydraulic connection provides some recharge to the overburden beneath the site cap.

Bulk hydraulic properties of the bedrock were characterized using water-level data from March 31, 2003, to April 4, 2003. During this period, there was no precipitation but the river stage increased at SW-1 due to dam releases. On
April 3, 2003, the river stage at SW-1 increased by $0.63 \mathrm{ft}$ and bedrock heads increased by $0.48 \mathrm{ft}$ at MW-7, $0.28 \mathrm{ft}$ at MW-8, and $0.05 \mathrm{ft}$ at MW-9.

Computed and observed ground-water levels resulting from river-stage fluctuations are shown in figure 26. Graphs show computed values of ground-water levels above an arbitrary zero datum (the antecedent water-level value at the initial time), as symbols plotted from relative time 0 to 600 minutes (approximately a half day).

River stage and simulated head fluctuations indicate that the bulk horizontal hydraulic conductivity of the bedrock, between MW-7 and the river, is one to two orders of magnitude greater than between MW-8 and the river and MW-9 and the river (table 4). A reasonable calibration was obtained 


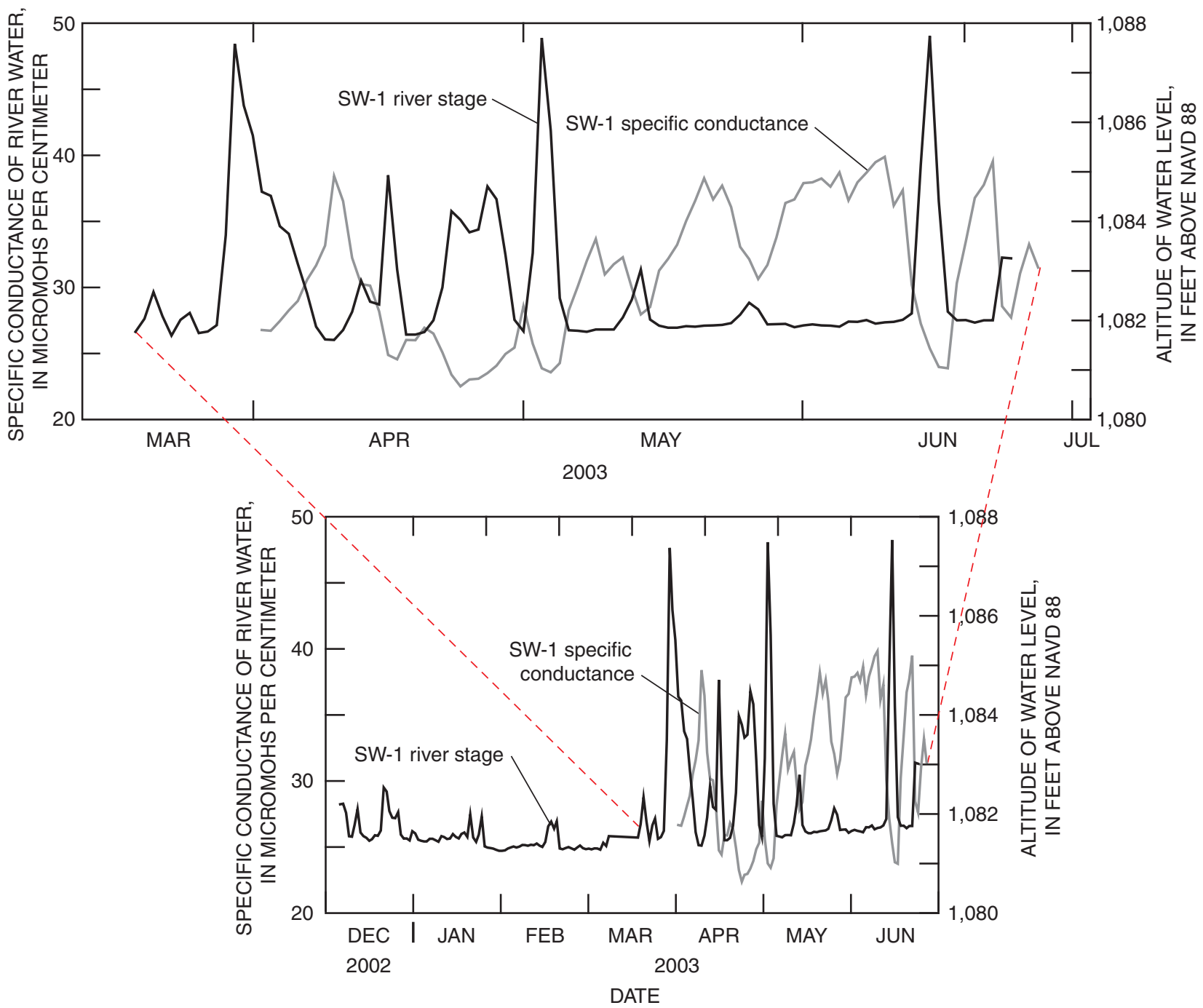

Figure 24. Average daily stage at SW-1 and specific conductance in the Androscoggin River at the cell-house site, Berlin, N.H.

between the observed ground-water levels from MW-7 and computed ground-water levels for a bulk hydraulic conductivity of about 2 to $20 \mathrm{ft} / \mathrm{d}$. In contrast, simulating the stream and aquifer interaction at MW-8 and MW-9 required a bulk hydraulic conductivity of about $0.2 \mathrm{ft} / \mathrm{d}$ (table 5 ).

No responses to river stage changes were observed at overburden wells MW-2, MW-3, and MW-5. This lack of response indicates a poor connection between the overburden and the river at these wells. A small response was measured at the overburden well MW-4 and indicates that the bedrock and overburden are hydraulically connected to each other and the river at this location.

Based on the estimated bulk hydraulic properties and measured gradients, computed instantaneous rates of ground- water discharge to the river from March 31, 2003, to April 4, 2003, are small (less than $0.1 \mathrm{ft}^{3} / \mathrm{s}$ ). A maximum rate of leakage from the river to the bedrock aquifer of less than $0.05 \mathrm{ft}^{3} / \mathrm{s}$ occurs in an early period of the increase in river stage. A maximum rate of ground-water discharge to the river of $0.03 \mathrm{ft}^{3} / \mathrm{s}$ is estimated late in the river stage decline. The computed flows are estimated on the basis of a specific hydrologic event and are not indicative of steady-state conditions.

Ground-water discharge to the river, under steady-state conditions, can be estimated from generalized head gradients and the estimated bedrock hydraulic properties. A flow rate of $0.0002 \mathrm{ft}^{3} / \mathrm{s}$ is computed assuming a bedrock bulk hydraulic conductivity of $0.2 \mathrm{ft} / \mathrm{d}$. Individual fracture zones, with high hydraulic conductivities, may produce zones with higher rates 


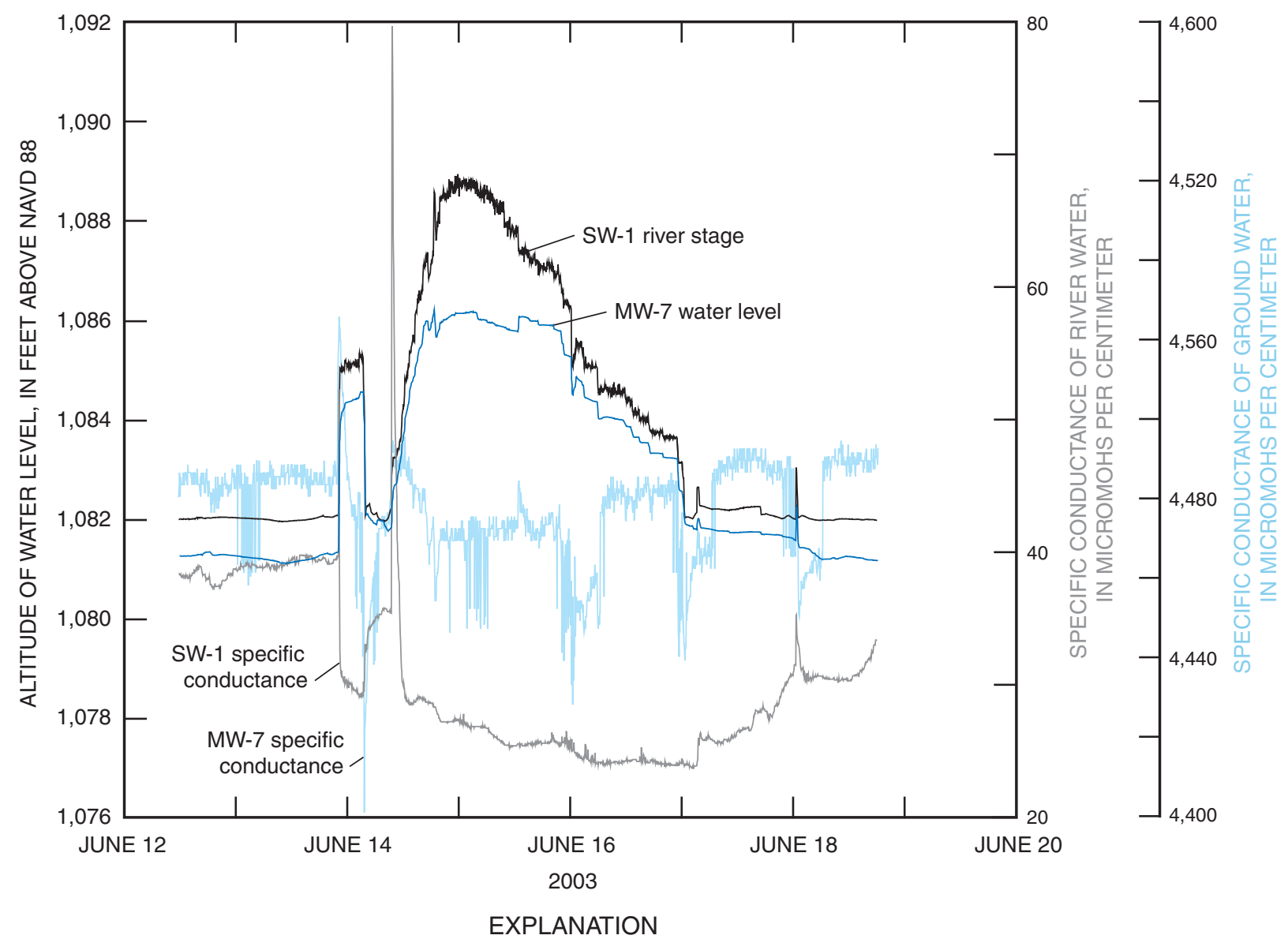

MONITORING SITES

MW-7 water level

MW-7 specific conductance

SW-1 river stage

SW-1 specific conductance

Figure 25. Five-minute-interval water level and specific conductance from bedrock well MW-7 and river stage SW-1 at the cell-house site, Berlin, N.H. (Location of sites shown on figure 2.)

of flow to the river. Nevertheless, the steady-state flow rates are most likely much less than the rates computed from March 31, 2003, to April 4, 2005, indicating that increased ground-water flow, and potentially transport of contaminants, from the site to the river occur during transient conditions.

\section{Geophysical Surveys}

Graphical results of ground-penetrating radar (GPR), two-dimensional resistivity, and borehole-geophysical logging surveys are presented in this section. Interpreted possible fracture characteristics are discussed with respect to each technique. An integrated analysis combining various techniques and geologic data are presented in the later section "Preliminary Hydrogeologic Characterization."

\section{Ground-Penetrating Radar}

GPR surveys (fig. 2) are presented for three locations at the riverbank (fig. 27) and one location on the cell-house site cap (fig. 28). Exposed bedrock at the riverbank provided ideal conditions for GPR signal transmission and data collection. The capped area at the cell-house site contains demolition debris, including metal, which limited the GPR survey potential. GPR data were collected using a point-survey mode because the rough surfaces at the site prevented data collection in a continuous-survey mode. Clay rich, electrically conductive till obscured GPR data collection at the perimeter of the site because the radar signal is generally attenuated in clayey till before it reaches bedrock (Ayotte and others, 1999). 
A. MW-7

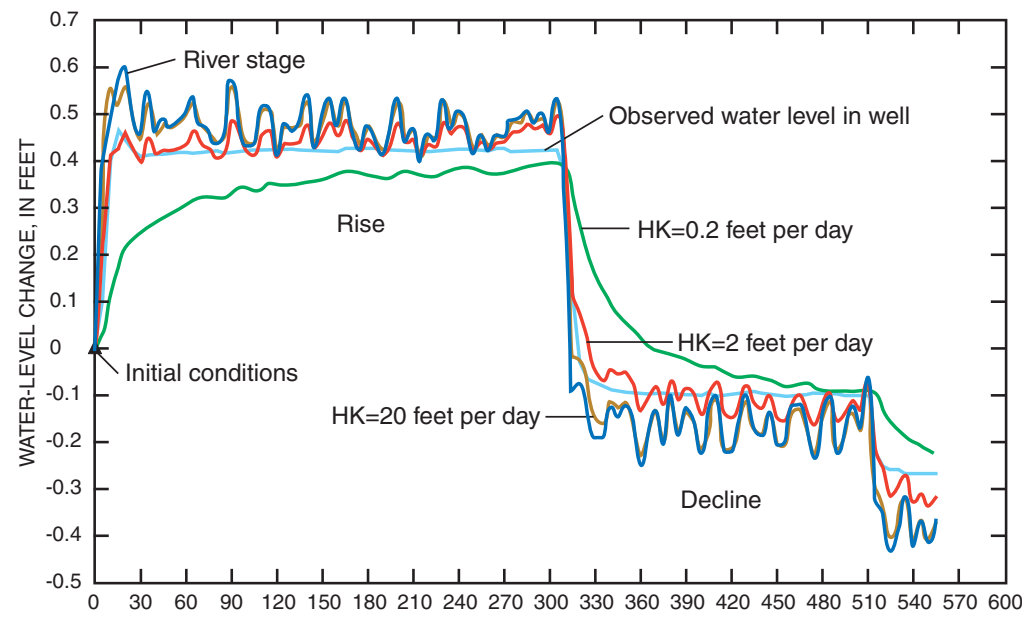

B. $M W-8$

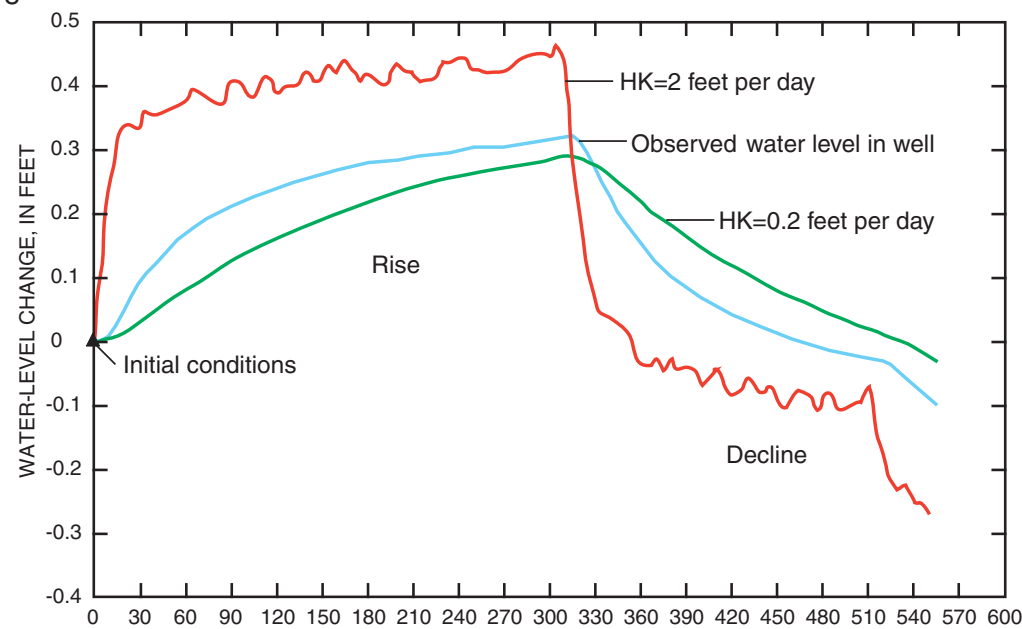

C. $\mathrm{MW}-9$

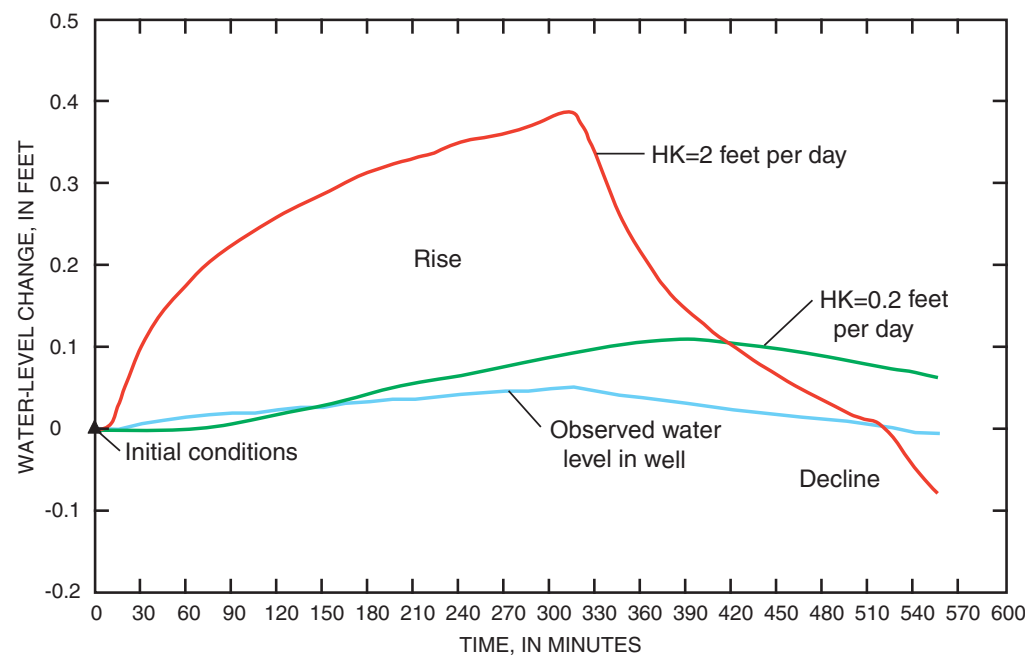

Figure 26. Observed water levels and computed water levels for the assigned horizontal hydraulic conductivity (HK) in response to river stage changes for bedrock wells (A) MW-7, (B) MW-8, and (C) MW-9 on April 3, 2003, cell-house site, Berlin, N.H. (Location of wells shown on figure 2.) 
Table 5. Summary of connectivity and estimates of bulk hydraulic conductivity between bedrock wells and the Androscoggin River, cell-house site, Berlin, N.H.

[Site location is shown on figure 2. --, no data]

\begin{tabular}{|c|c|c|c|c|c|c|}
\hline Monitoring site & $\begin{array}{l}\text { Water body or } \\
\text { well type }\end{array}$ & $\begin{array}{l}\text { Reported screen in- } \\
\text { terval, in feet below } \\
\text { measurement point }\end{array}$ & $\begin{array}{l}\text { Distance } \\
\text { from river, } \\
\text { in feet }\end{array}$ & $\begin{array}{l}\text { Rise in ground-water } \\
\text { level from river stage } \\
\text { increase on April 3, } 2003\end{array}$ & $\begin{array}{c}\text { Estimated bulk } \\
\text { horizontal hydraulic } \\
\text { conductivity, } \\
\text { in feet/day }\end{array}$ & Comment \\
\hline SW-1 & River & -- & 0 & -- & $\begin{array}{l}- \\
--\end{array}$ & \\
\hline MW-7 & Bedrock & $18.4-31.4$ & 45 & 0.48 & $2-20$ & \\
\hline MW-2 & Overburden & 6-18 & 45 & 0 & -- & No response \\
\hline MW-8 & Bedrock & $28-46$ & 65 & .28 & 0.2 & \\
\hline MW-3 & Overburden & $5.5-10.5$ & 65 & 0 & -- & No response \\
\hline MW-9 & Bedrock & $19.3-37.3$ & 145 & .05 & .2 & \\
\hline MW-5 & Overburden & $6-12$ & 142 & 0 & $\begin{array}{l}-- \\
--\end{array}$ & No response \\
\hline $\mathrm{P}-21$ & Overburden & $9-13$ & 190 & -- & -- & \\
\hline MW-4 & Overburden & $11.9-22.9$ & 165 & .02 & Not estimated & \\
\hline P-4A & Bedrock & $37.7-49.7$ & 165 & -- & -- & \\
\hline SW-2 & Canal & -- & 180 & -- & -- & \\
\hline
\end{tabular}

Survey lines 1, 2, and 3 (fig. 2), collected directly on rock on the riverbank, indicate mostly shallow and a few steeply dipping reflections (fig. 27). Due to the GPR antenna transmitter and receiver configuration, and the nature of radar waves, surface GPR surveys are more likely to identify horizontal rather than vertical reflectors. Where the survey crosses the pool at the river's edge, the radar signal is obscured below the bottom of the pool due to multiple reflections. Several electrically conductive anomalies indicating fractures at depth, along lines 1-3 (fig. 27), are consistent with the fracture patterns observed at the riverbank. GPR lines 1 and 2 (fig. 2) show similar horizontal and shallow-dipping reflectors from 50 to $100 \mathrm{ft}$ along the line (fig. 27). These reflectors likely represent contacts or fractures associated with gneiss, chlorite-schist, and pegmatite lenses. Inspection of bedrock cores from boreholes in the capped area (boreholes drilled for wells MW-4 and MW-10) indicate that alternating lenses of gneiss, chlorite schist, and pegmatite, similar to that seen at the riverbank, are present in the capped area.
At the southern end of the riverbank, GPR-survey results were not consistent between survey lines 2 and 3 (fig. 27). In addition to shallow horizontal reflections, a steeply dipping reflector is centered at $330 \mathrm{ft}$ on line 2 (fig. 27).

GPR surveys were used on the capped area to identify depressions in the bedrock surface and potential fracture zones. Interpretation of GPR profiles was difficult because it was not possible to distinguish unknown debris in the overburden material from geologic features. However, four layers are presented for line 26 (fig. 28) that were interpreted from reflections in the GPR profile: (1) woodchips and geomembrane cap, 3-4 ft thick; (2) overburden, 3-10 ft thick; (3) saturated overburden, $0-5 \mathrm{ft}$ thick and (4) bedrock. Shallow depths to bedrock are confirmed through soil-boring data and observations of outcrops adjacent to the capped area. There is a 2-ft-deep depression in the surface of the bedrock, relative to surrounding areas, between 130 and $150 \mathrm{ft}$ along line 26 (fig. 28) that could be the result of a fractured bedrock surface. 


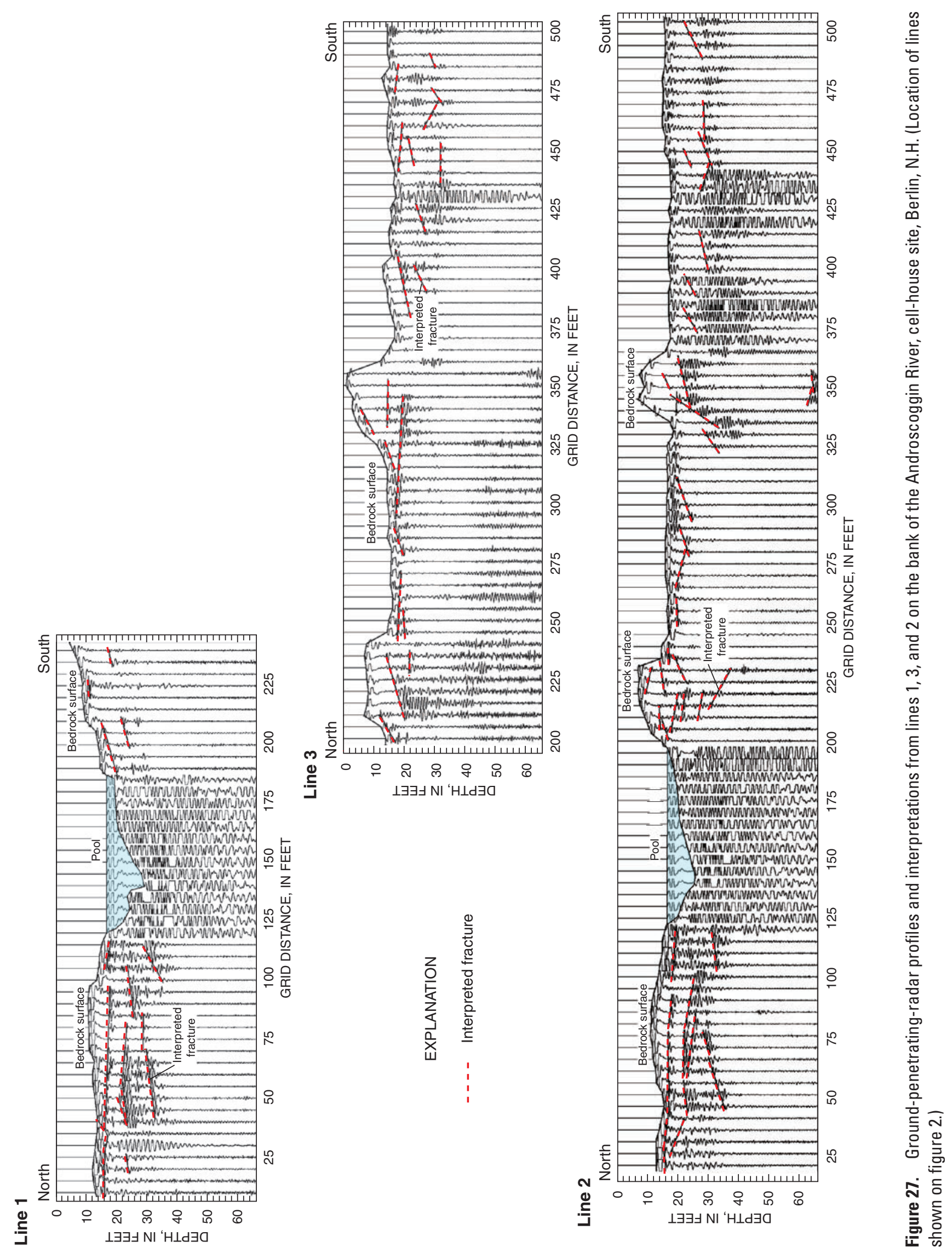




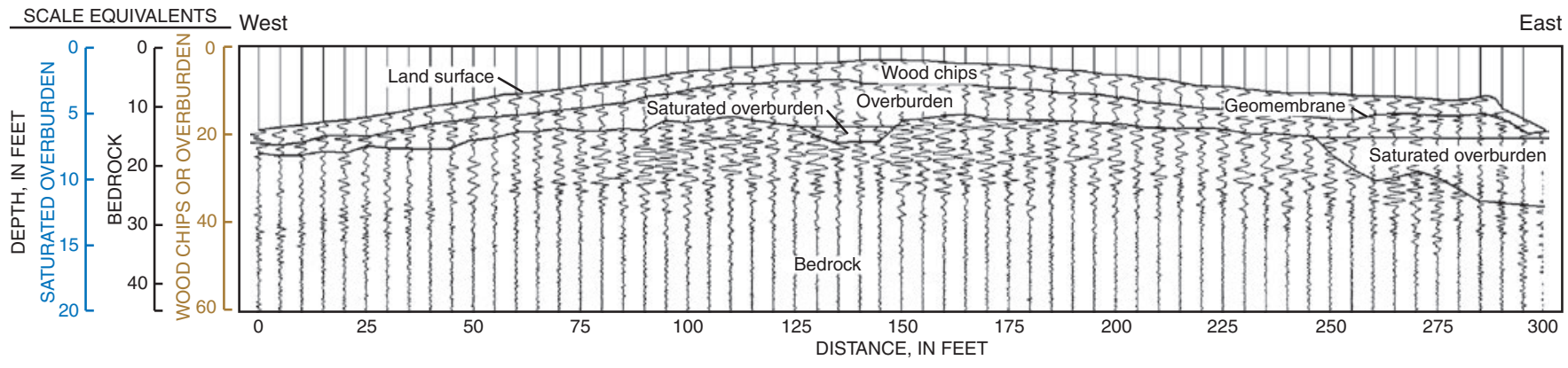

Figure 28. Ground-penetrating radar profiles from line 26 on the capped area of the cell-house site, Berlin, N.H. (Depth scale is material dependent. Location of line shown on figure 2.)

\section{Two-Dimensional Resistivity}

Resistivity surveys were conducted at two lines (fig. 29) on the riverbank and at 11 lines (figs. 30-34) around the perimeter of the cell-house site (fig. 2). Electrical anomalies, represented by resistivity values relatively lower than the surrounding rock (less than about 1,000 ohm-ft), are apparent in most lines.

Resistivity results from lines 1 and 2 (fig. 29) indicate electrically conductive anomalies in the bedrock that are in the same areas as the reflections seen in the GPR results in figure 27. Various anomalous areas along resistivity line 1 (fig. 29) have resistivities less than $150 \mathrm{ohm}-\mathrm{ft}$ and probably represent fracture zones containing contaminated ground water. A folded chlorite-schist lense in this area, with vuggy fractures and chlorite alteration, dips $47^{\circ}$ in a direction $\left(055^{\circ}\right)$, is a major structural feature on the riverbank, and is probably associated with the low-resistivity anomaly. Water levels in bedrock well MW-7 indicate a hydraulic connection between the fractured bedrock and the river in this area (fig. 2). The high resistivity anomalies from $310 \mathrm{ft}$ to the southern end of line 2 in the dipole-dipole resistivity survey (fig. 29) are the result of missing data points. More data were available using the Schlumberger array, and survey results (fig. 29) indicate that conductive anomalies are present that may represent fracture zones.

Electrically conductive anomalies, which may represent bedrock fracture zones, are apparent in resistivity profiles at the southern and eastern perimeter of the cell-house site. Trends of anomalies are approximate and measured by projecting anomalies between lines on a map. Resistivity profiles for lines 8 and 9 (fig. 30), at the southwestern perimeter of the site, indicate potentially fractured bedrock at the western end of the barrier wall. The center of the anomalies (fig. 30), at about $140 \mathrm{ft}$ between lines 8 and 9 , strikes $80^{\circ}$, coincides with a depression in the bedrock surface, and is interpreted as a potential fracture zone. Survey line 9 indicates a more conductive anomaly in the bedrock than on line 8. Buried metal debris along line 8 may obscure conductive features at depth.

On the southern perimeter of the site, resistivity profiles from lines 10,11, and 12 (fig. 31) indicate an anomaly with a trend of $160^{\circ}$ in all three survey lines. A waterline indicated on a historical map of the site (Dennis Pednault, Frazier Paper, Inc., written commun., 2003) may be the cause of the anomaly. Electrically conductive features near the surface of the profiles may be caused by buried metal from the demolition of buildings or waterlines. Electrically conductive features below the interpreted surface of the bedrock along these lines are possible bedrock-fracture zones.

Potential fracture zones with vertical and southern apparent dips appear to have trends that could be projected towards the site at the eastern perimeter. A fracture zone is indicated between lines 16,17 , and 18 at approximately 50 to 90,120 to 200 and $340 \mathrm{ft}$ to the end along the survey lines, respectively (fig. 32) with a trend of approximately $80^{\circ}$ and a vertical dip. This trend is towards the site and barrier wall but the feature does not appear in line 14, which is between lines 16-18 and the site, thus indicating the feature probably does not continue to the site. Near-surface anomalies, possibly a waterline, make interpretations uncertain in this region. At the southern end of lines 16 and 17, at approximately 490 and $610 \mathrm{ft}$ along the lines, respectively, is an anomaly with a $100^{\circ}$ strike and a vertical dip. When projected towards the site this feature may pass just inside the barrier wall on the southeastern corner. Between lines 14, 16, and 17, at approximately 615,330 , and $435 \mathrm{ft}$, respectively, is an anomaly with three possible trends (fig. 32). If it is interpreted as the northern boundary of the anomaly, where the electrical contrast is sharpest, the strike is $60^{\circ}$ and the feature can be projected along strike just inside the southeastern corner of the barrier wall. The projected strike of 
Line 1, Dipole-dipole array

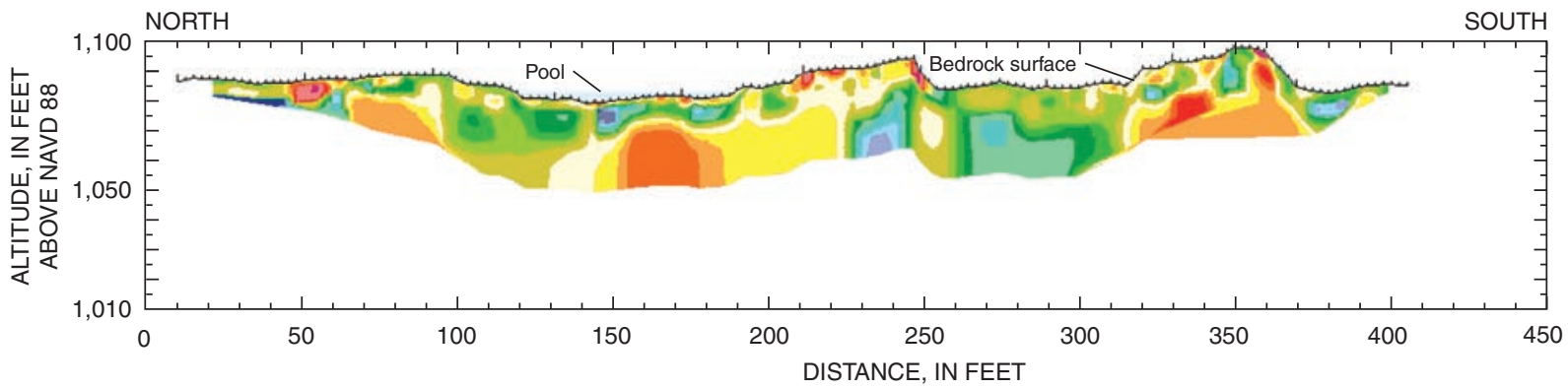

Line 1, Schlumberger array

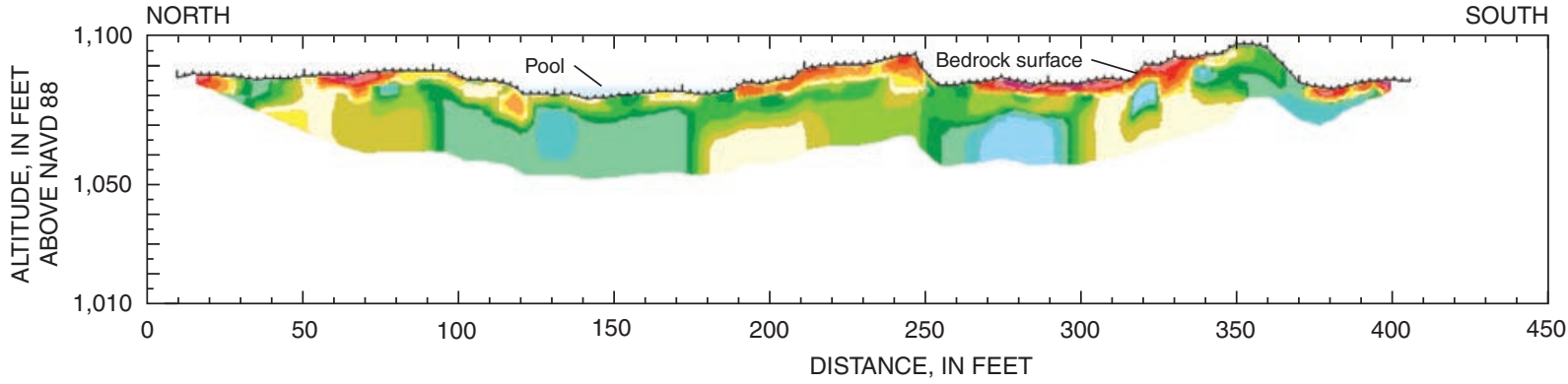

Line 2, Dipole-dipole array

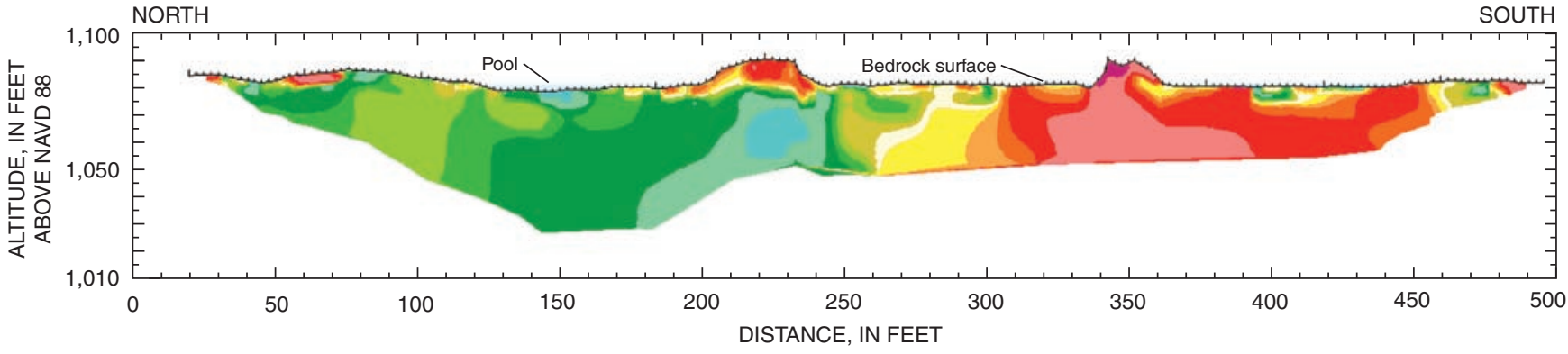

Line 2, Schlumberger array

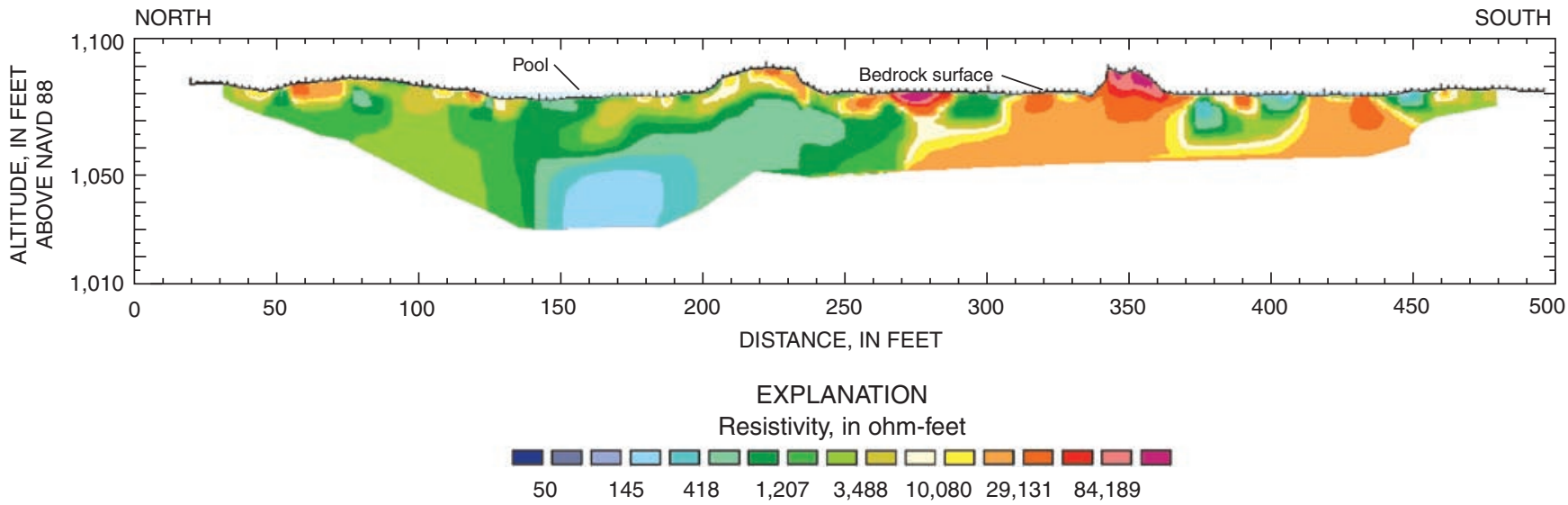

Figure 29. Resistivity profiles from lines 1 and 2 on the bank of the Androscoggin River, cell-house site, Berlin, N.H. (Location of lines shown on figure 2.) 


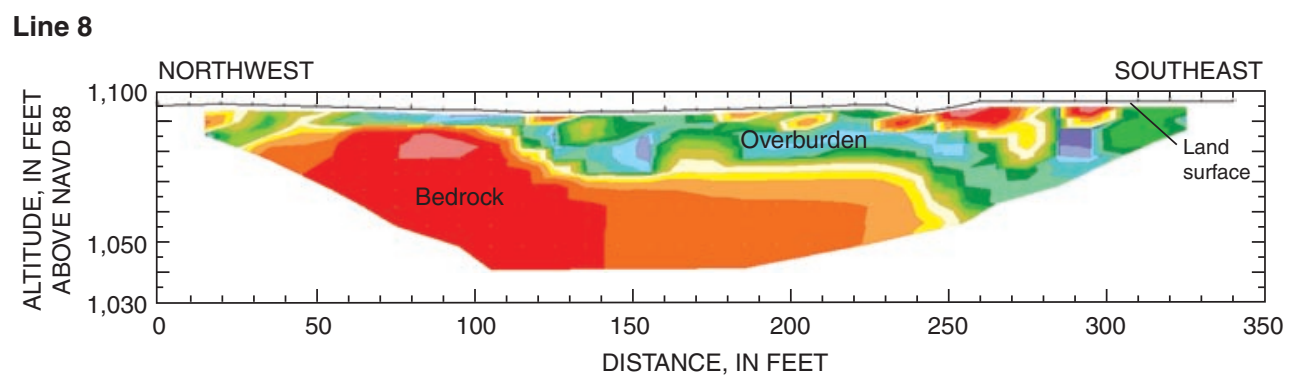

Line 9

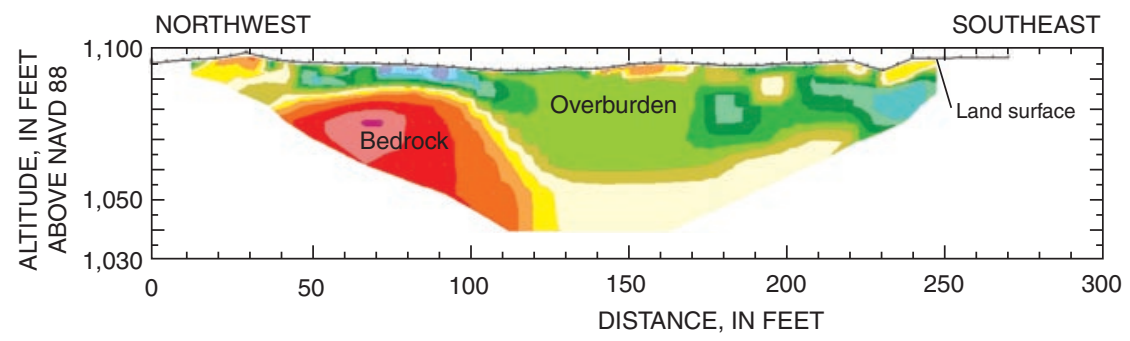

EXPLANATION

Resistivity, in ohm-feet

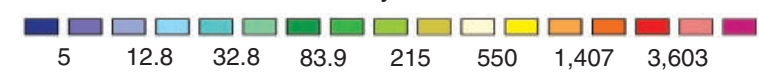

Figure 30. Resistivity profiles showing dipole-dipole array from lines 8 and 9 on the southwestern perimeter of the cell-house site, Berlin, N.H. (Location of lines shown on figure 2.)

the anomaly intersects line 13 if it is measured closer to the center of the anomaly or it may be correlated with an anomaly at 210 or $265 \mathrm{ft}$ along line 13 having $110^{\circ}$ and $85^{\circ}$ strikes, respectively. The anomaly has moderate apparent dips to the south measured on lines 17 and 16, respectively. Another electrical anomaly that may represent a fracture zone is apparent in lines 13 and 14 (fig. 32) at 130 and $510 \mathrm{ft}$, respectively, with an $85^{\circ}$ strike and a vertical dip. This feature may project towards the site under the barrier wall. The $60^{\circ}$ and $85^{\circ}$ trending anomalies are of interest because they are parallel to a dominant fracture peak (fig. 16A).

\section{Borehole-Geophysical Logs}

Borehole-geophysical logs collected at wells MW-14 and MW-15 are presented in figures 33 and 34, respectively. There are fewer fractures in MW-14 (fig. 33) than in MW-15

(fig. 34); however, shallow dipping fractures are present in both wells at about 28 and $30 \mathrm{ft}$ (at an elevation of about $1,074 \mathrm{ft}$ ) below top of casing that show the strongest indications of ground-water flow. Fluid property logs of wells MW-14 and MW-15 (figs. 33 and 34, respectively) show fluid temperature and conductance inflections at this depth, which indicate a hydraulically active fracture. The shallow subhorizontal fracture at about $1,074 \mathrm{ft}$ likely provides the hydraulic connection to the river noted in the water-level analysis of wells MW-7 and MW-8. Electrically conductive ground water (greater than 4,000 $\mu \mathrm{S} / \mathrm{cm}$ ) was detected at wells MW-7 (fig. 23) and MW-14 (fig. 33) near the largest resistivity anomaly at about $235 \mathrm{ft}$ along line 1 and $225 \mathrm{ft}$ along line 2 (fig. 29) with a moderate apparent dip to the northeast.

Most fractures in borehole MW-14 had shallow dips to the east with a few steeply eastward dipping fractures (fig. 35A). Fractures in MW-15 had a greater range of dips but were mostly to the east (fig. 35B). Geologic mapping on the riverbank, and the core logs of wells MW-14 and MW-15 (Joseph Schmidl, Weston Solutions, written commun., 2004), indicate that these zones likely represent subhorizontal fractures within the chlorite schist.

Several fractures in wells MW-14 and MW-15 had indications of ground-water flow (on the basis of fluid properties). Fractures in MW-14 (fig. 33) at 21, 33, and $38.5 \mathrm{ft}$ also align with fractures seen in the core $\log$ (Joseph Schmidl, Weston Solutions, written commun., 2004). Indications of fractures and ground-water flow in MW-15 were seen at $34.5 \mathrm{ft}$ in the fluid $\log$ and caliper log (fig. 34). 
Line 10

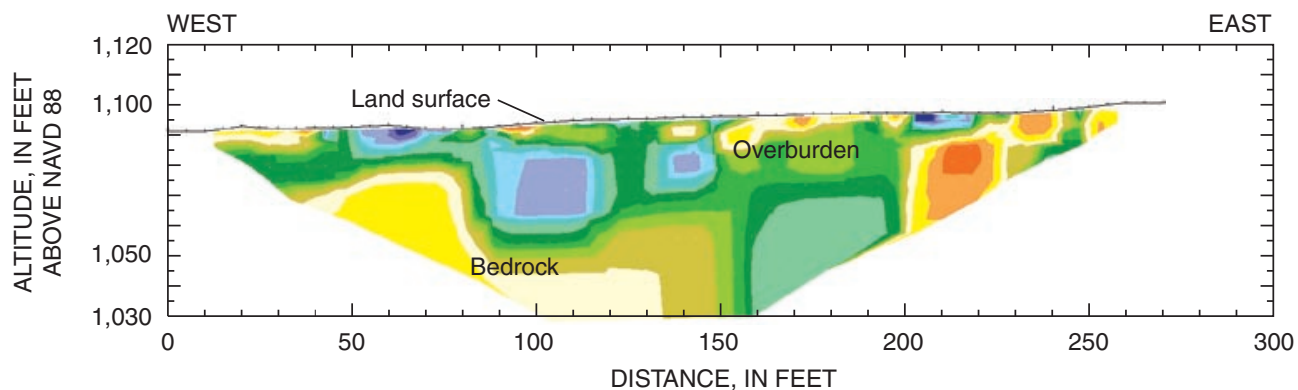

Line 11

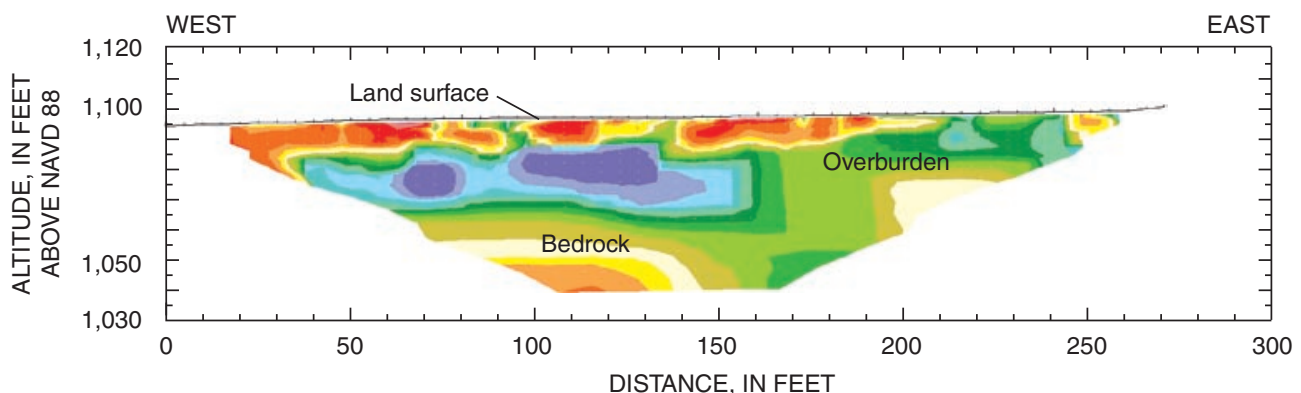

Line 12

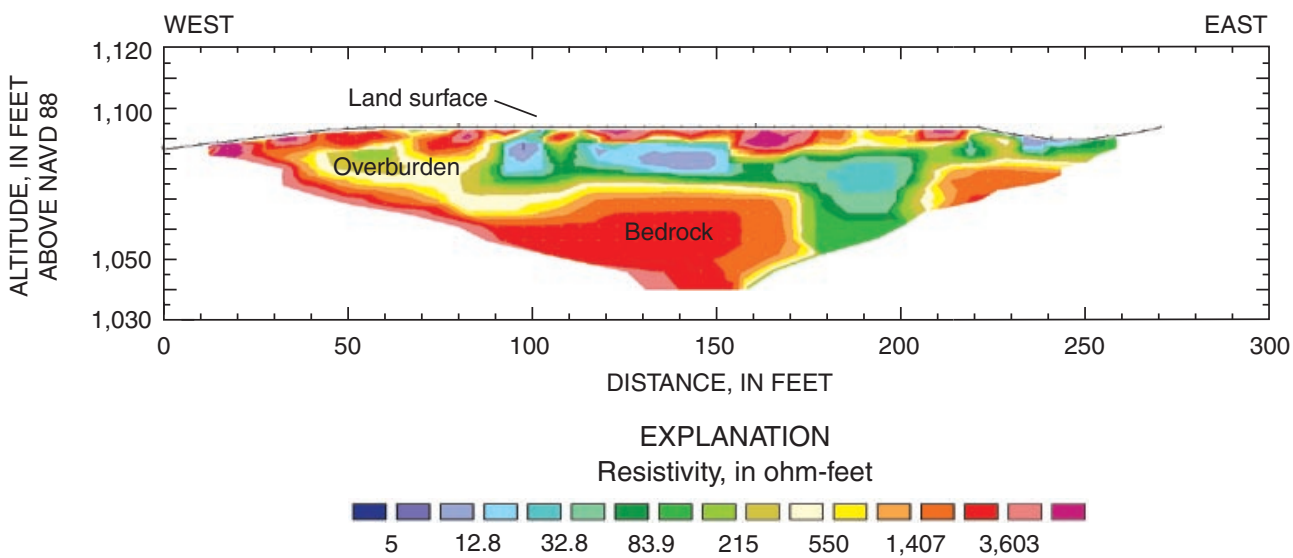

Figure 31. Resistivity profiles showing dipole-dipole array from lines 10, 11, and 12 on the southern perimeter of the cell-house site, Berlin, N.H. (Location of lines shown on figure 2.) 
NORTH

Line 18

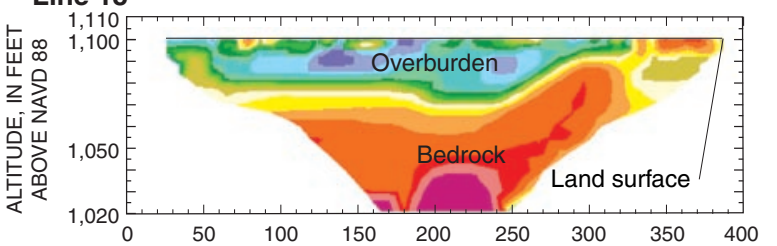

EXPLANATION

Resistivity, in ohm-feet
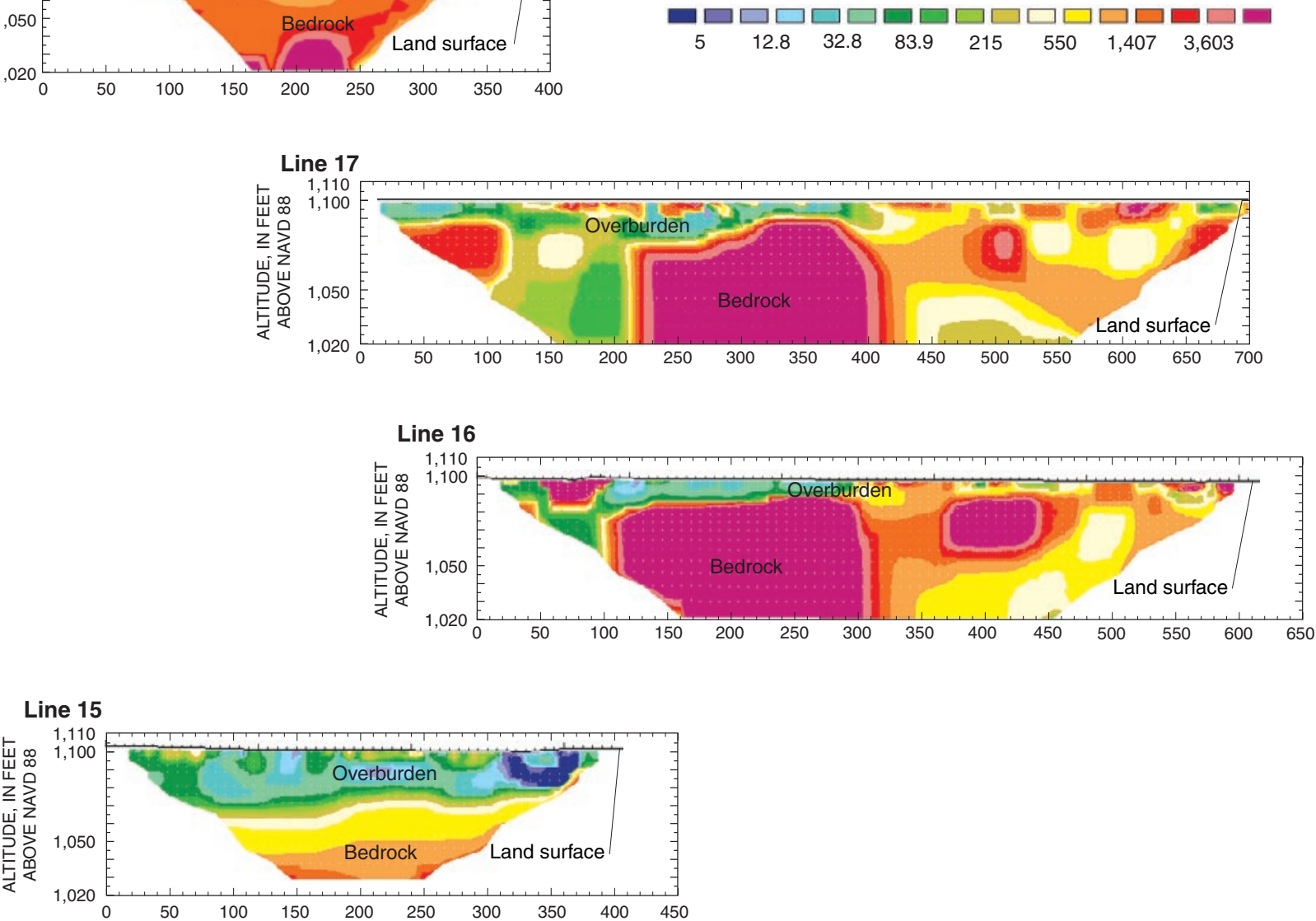

\section{Line 14}
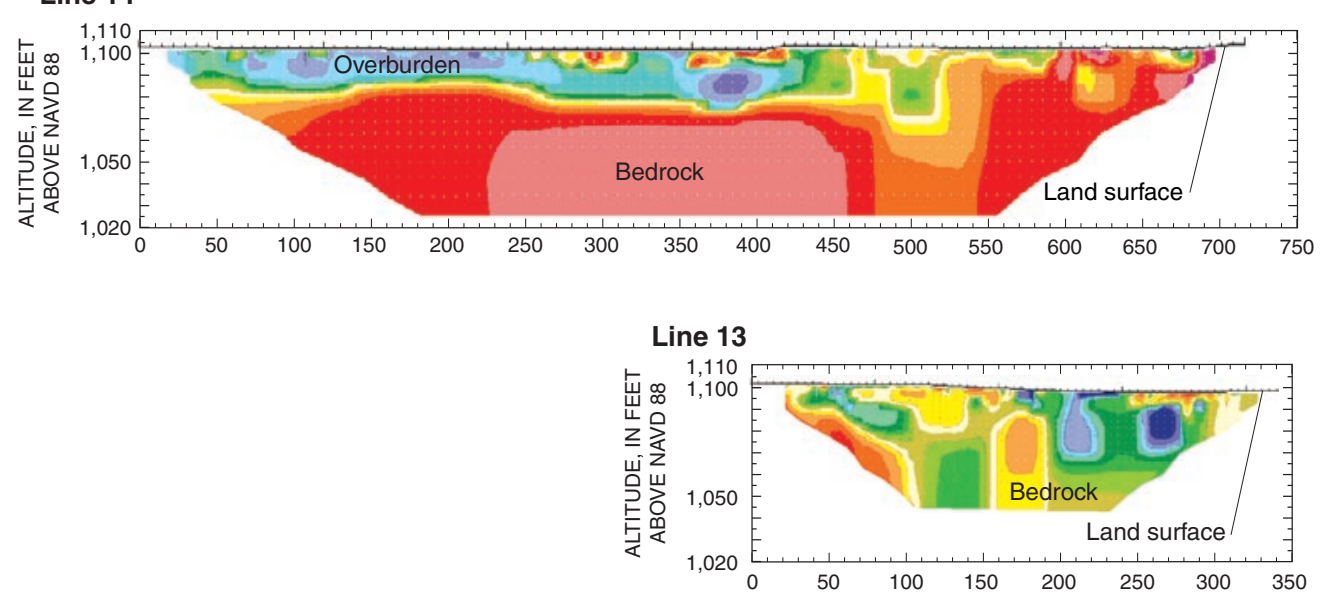

DISTANCE, IN FEET

Figure 32. Resistivity profiles showing dipole-dipole array from lines 13 through 18 on the eastern perimeter of the cell-house site, Berlin, N.H. (Location of lines shown on figure 2.) 


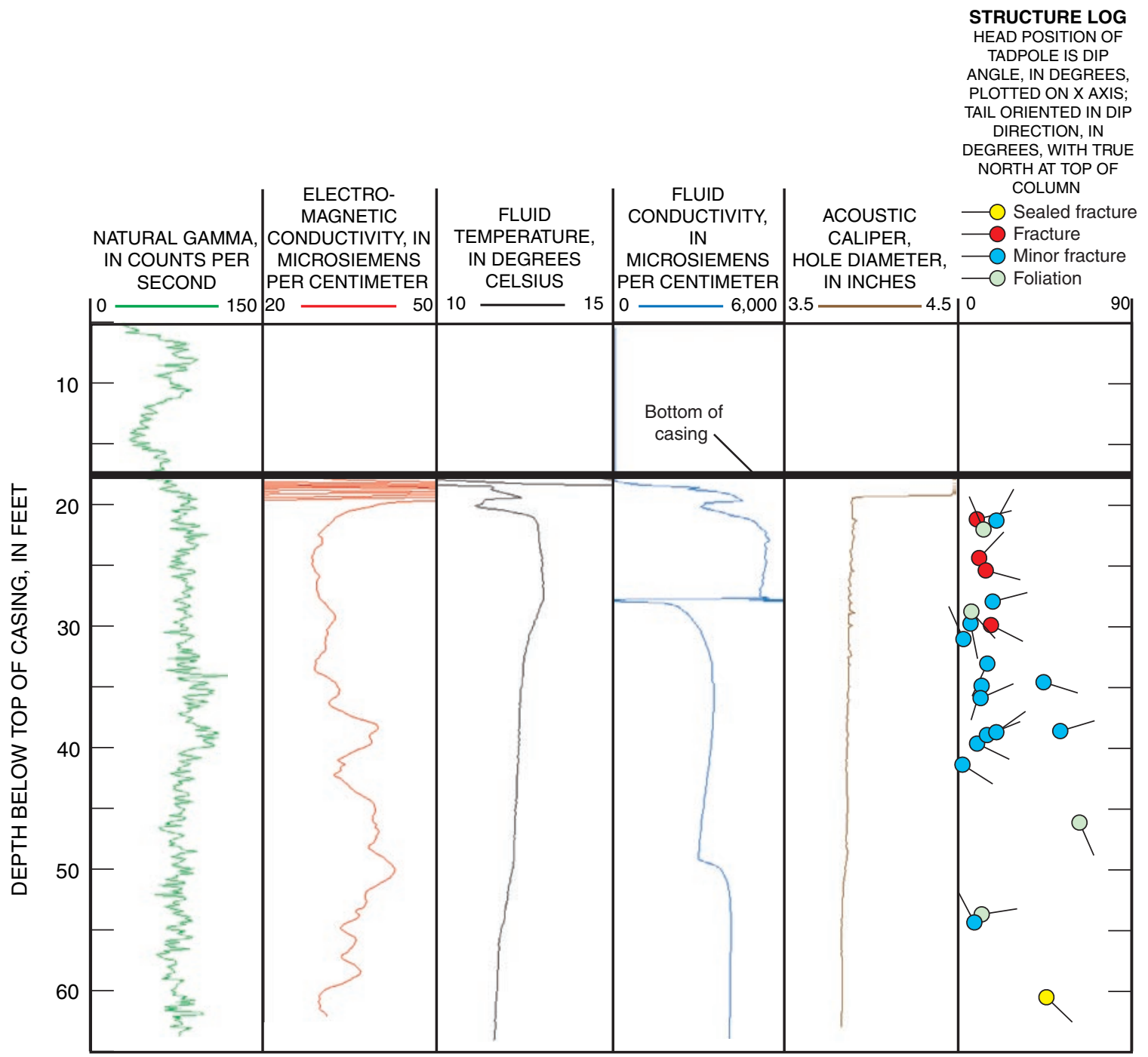

Figure 33. Borehole-geophysical logs of well MW-14, cell-house site, Berlin, N.H. (Location of well shown on figure 2.)

\section{Preliminary Hydrogeologic Characterization}

A conceptual model and preliminary hydrogeologic characterization of ground-water flow at the site shows that ground water flows east to west across the site and likely follows a stair-step pattern within the bedrock toward the river (fig. 36). In addition, ground water in the overburden aquifer is poorly connected to the bedrock aquifer through near vertical bedrock fractures. The site cap limits, or eliminates, recharge from precipitation. Regional ground-water flow may enter the cell-house site at the site perimeter. Nearby lineaments (fig. 1) may identify preferential fractured bedrock ground-water-flow paths to the site perimeter.

Geologic mapping found that lenses of gneiss, 6-9 $\mathrm{ft}$ thick, containing near vertical fractures are bounded by moderately dipping, vug filled, chlorite-schist lenses bounded by fractures and subhorizontal unfractured pegmatite. Subhorizontal or moderately dipping fractures connect the vertical fractures of the bulk rock. Inspection of borehole cores (appendix 1) and geophysical-survey results indicate this geologic pattern likely extends east from the riverbank across the cell-house site. 


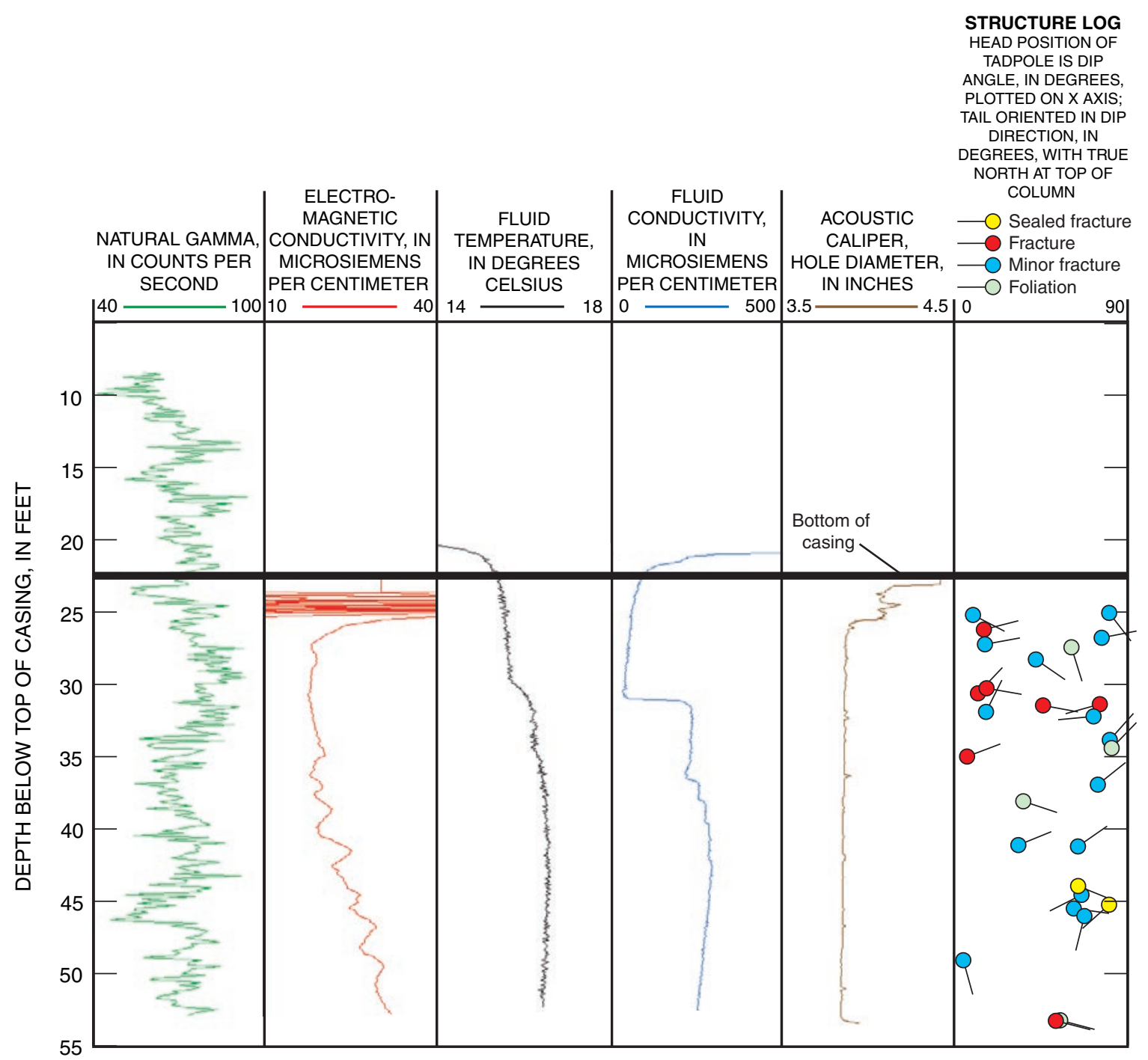

Figure 34. Borehole-geophysical logs of well MW-15, cell-house site, Berlin, N.H. (Location of well shown on figure 2.)

The bedrock aquifer at the site is connected to the Androscoggin River as indicated by results of geologic mapping and hydraulic analysis. Geologic mapping at the riverbank, where elemental mercury has repeatedly been found on the outcrop and along fractures exposed at the bank, shows that fracture frequency varies with rock type (plate 1). For example, pegmatites are relatively unfractured compared to gneisses. Fracture patterns observed in the riverbank support interpretations of geophysical results and are similar to what was observed in bedrock cores from boreholes near the riverbank. Subhorizontal fractures probably serve as the primary hydraulic conduit for ground-water flow between the near vertical fractures in the bulk rock and the river.
The hydraulic-conductivity of individual fractures near the river may be relatively high as indicated by rapid waterlevel fluctuations in some observation wells. The high hydraulic conductivity estimate (2-20 ft/d) from well MW-7 is likely affected by a direct flow path in a more open subhorizontal fracture similar to those noted in the nearby borehole associated with MW-14 (fig. 33). Conversely, a low hydraulicconductivity estimate of $0.2 \mathrm{ft} / \mathrm{d}$, based on water level data at wells MW-8 and MW-9, is likely representative of the steeply dipping fractures in gneiss that make up the bulk of the rock.

Data on fracture density indicate that ground-water storage in bedrock at the site likely occurs in the near vertical fractures in the gneiss that comprise most of the bedrock 
A. Bedrock well MW-14

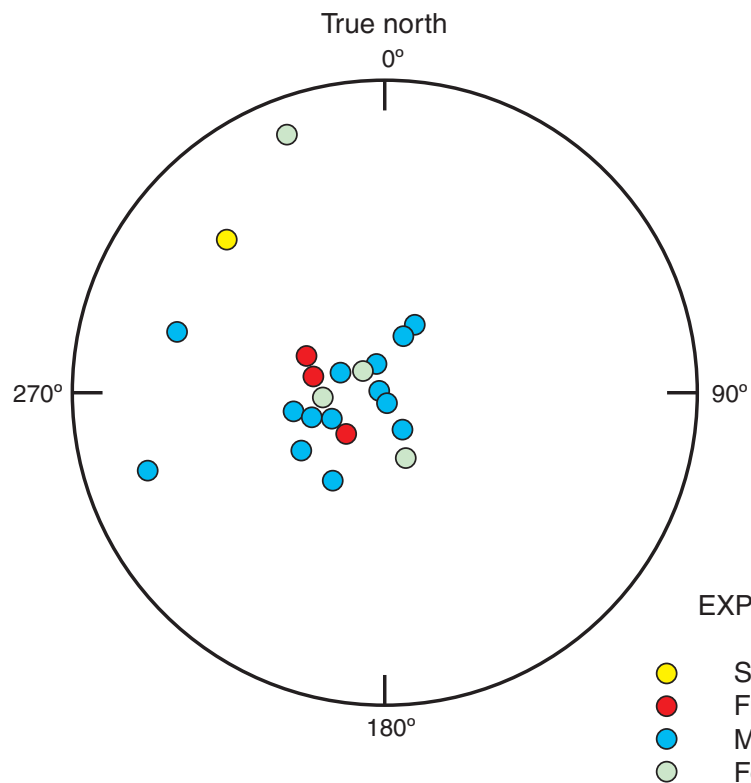

B. Bedrock well MW-15

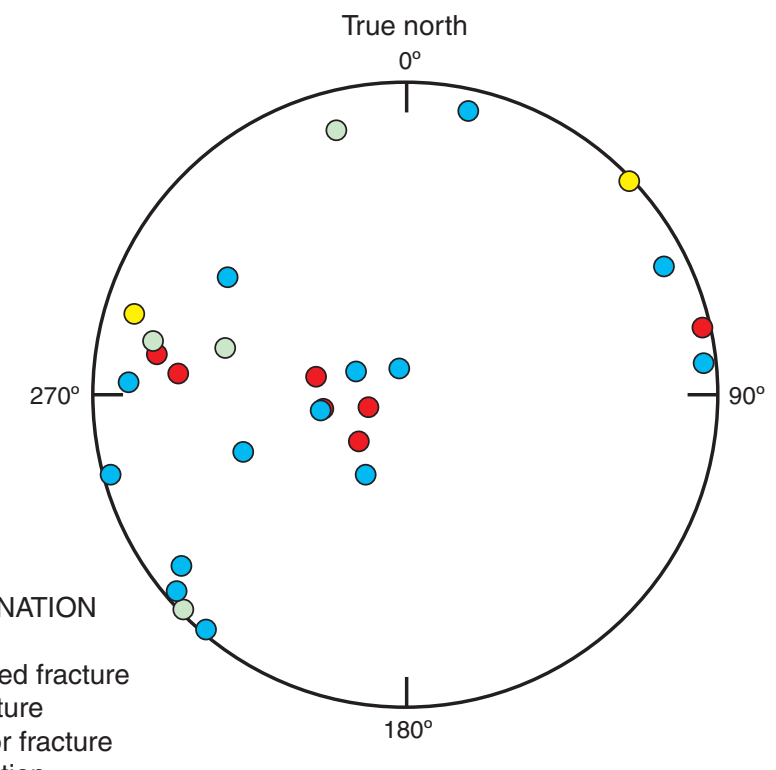

Figure 35. Lower hemisphere stereonets showing orientation with poles to plane of bedrock structure in wells $(A) M W$ 14 and (B) MW-15, cell-house site, Berlin, N.H. (Location of wells shown on figure 2.)

aquifer. The low hydraulic conductivity of the near vertical fracturing is probably the limiting hydraulic conductivity in the bedrock aquifer at the site. In fractured rock, the hydraulic conductivity of the aquifer, over a scale similar to the field site, is controlled by the small fractures of the dominant fracture network (Tiedeman and others, 1997). Therefore, the bulk hydraulic conductivity for the bedrock aquifer across the site is estimated to be about $0.2 \mathrm{ft} / \mathrm{d}$.

The overburden aquifer, which consists of till and fill materials, is perched in places and poorly connected to the bedrock aquifer and, therefore, isolated from short-term changes in river stage downstream of the dam. Based on analysis of water levels, the geomembrane cap effectively limits or eliminates recharge from precipitation. However, the overburden is likely recharged from ground-water inflow that either moves through or under the barrier wall or from the underlying bedrock aquifer. To the east, the overburden aquifer is hydraulically connected to the canal, although this aquifer is likely in poor connection because of canal-bottom sediments, and the aquifer has a dampened response to changes in canal water levels. Despite that the bedrock aquifer is a likely source of water to the overburden aquifer inside the barrier, the overburden aquifer is poorly connected to the underlying bedrock aquifer through tight vertical fractures, and is perched above the bedrock aquifer on the west side of the site.
The implications of site hydrogeology on mercury storage and transport require additional studies. The physical properties of dissolved mercury in ground water indicates that this form of mercury likely follows flowpaths through the bedrock aquifer indicated by the head gradients shown in figure 20 and in the conceptual model (fig. 36). The presence of liquid (elemental) mercury has been observed on the riverbank at the site and is often associated with chlorite schist lenses at the middle of the site (plate 1, cell B25) and further south or downstream (plate 1, cell C45). It is not known if the transport of the elemental mercury to these lenses is through fractures from within the cell-house site, or through redistribution from the riverbed during high turbulent river flows. If elemental mercury is moving in the bedrock aquifer it may flow "downhill" through connected fractures, possibly to the east-southeast in the direction of the dip of fractures and chlorite-schist lenses, in a gravity-driven manner that is independent of the hydraulic-head gradient shown in figure 20 and indicated in the conceptual model (fig. 36). Solid amalgams of mercury may have been transported to the riverbank through mechanical means (not associated with water flow) or may have originated as elemental (liquid) mercury that converted to an amalgam after being transported to the riverbank by ground and or surface waters. 


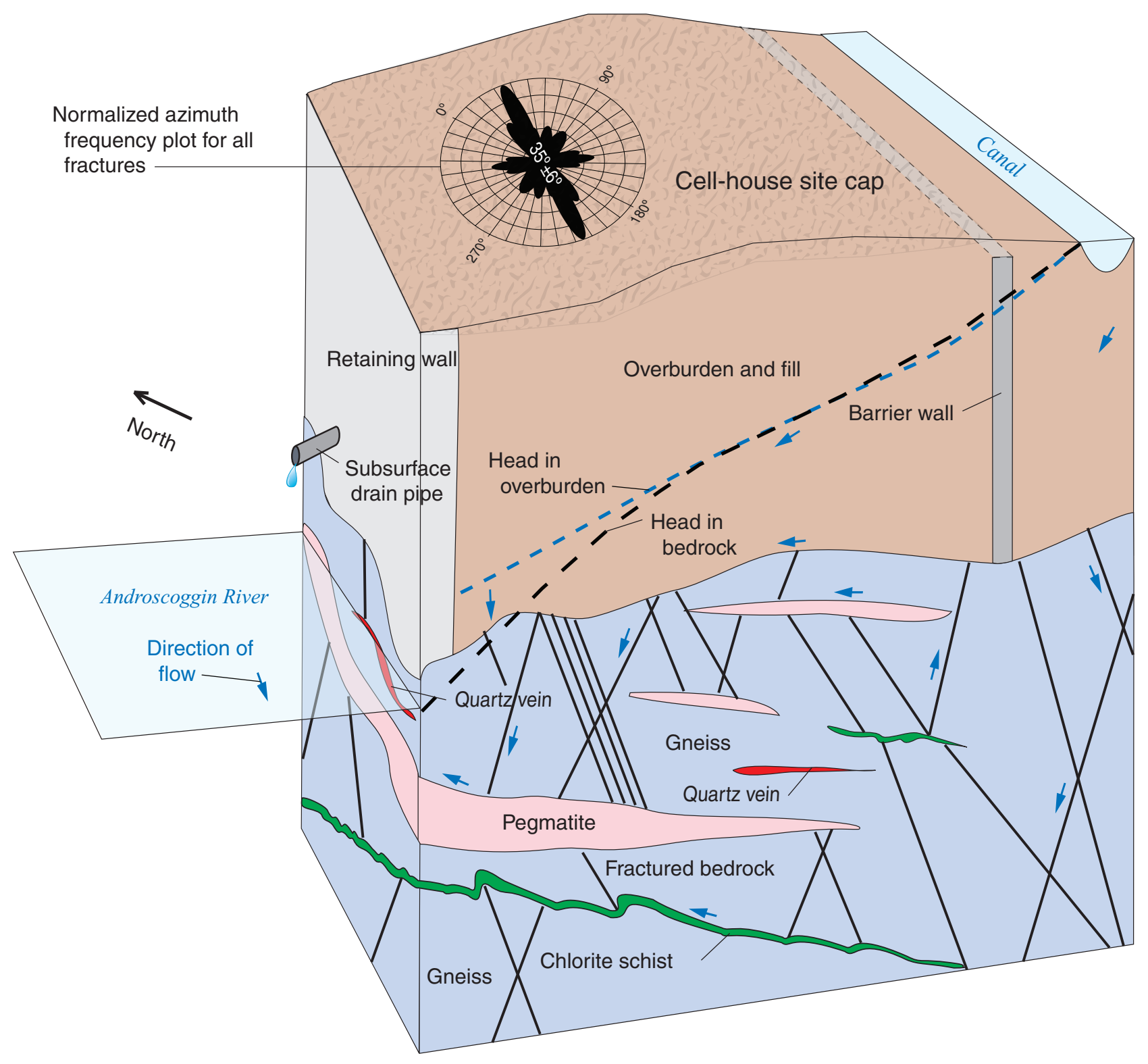

Not to scale

Figure 36. Conceptual model of the hydrogeology at the cell-house site, Berlin, N.H. 


\section{Summary}

The U.S. Geological Survey, in cooperation with the New Hampshire Department of Environmental Services, Waste Management Division, mapped geology, monitored water-levels, and conducted geophysical surveys to characterize fractured bedrock at a former chlor-alkali plant (cell-house site) in Berlin, N.H. The cell-house site is primarily a fractured-rock setting where little was previously known about the geology and hydrogeology of the site. Site characterization, based on data collected during the fall of 2002 through the winter of 2004, provides a geologic description and preliminary understanding of hydrogeology to guide ongoing remedial investigations for mercury contamination.

Bedrock in the Androscoggin River, along the west side of the cell-house site, consists of gneiss with thin discontinuous lenses of chlorite schist and discontinuous tabular pegmatites. Two distinct fracture domains overlap near the site. One domain, south and east of the Androscoggin River, is characterized by steeply dipping fractures with principal trends to the northwest. The second domain, north and west of the river, is characterized by steeply dipping fractures with principal trends to the north. The cell-house site is near the transition zone between these domains and locally shows principal trends common to both fracture domains.

The fractured-rock conceptual model of the site consists of steeply dipping fractures in gneiss that terminate on subhorizontal fractures along contacts with pegmatite, on non-planar fractures, or at moderately dipping contacts with chlorite schist. The rock types and fractures observed at the riverbank are believed to extend to the east beneath the cell-house site. Fractured-rock characteristics of the site include:

- Weakly developed gneissosity with non-planar (irregular) fractures with a 1-mm (0.04 in.) aperture that generally conform to the gneissosity. Gneissosity is folded about an axis that plunges N. $48^{\circ} \mathrm{E}$. at $34^{\circ}$. Fractures that are subparallel to the gneissosity are folded about an axis that plunges $\mathrm{N} .55^{\circ} \mathrm{E}$. at $47^{\circ}$.

- Foliated chlorite-schist lenses, and fractures that parallel these lenses, are folded about an axis that plunges N. $37^{\circ}$ E. at $26^{\circ}$ SE. Vugs in the chlorite schist may contribute to the porosity of fractures in these lenses.

- Fracture intensity is a function of rock type. Rocks at the site, from most to least fractured, include

(a) chlorite schist, (b) fine-grained non-foliated gneiss,

(c) coarse-grained weakly foliated gneiss, and

(d) pegmatite.

- Fracture aperture varies with fracture type. In general, the aperture of parallel fractures sets are generally less than $1 \mathrm{~mm}$ (less than $0.04 \mathrm{in}$.). Non-planar (irregular) fractures, locally associated with chlorite schist, often have apertures of about $1 \mathrm{~mm}$ (0.04 in.). En échelon fractures have the greatest aperture, generally $1-2 \mathrm{~mm}$ $(0.04-0.08 \mathrm{in}$.) and as much as $5 \mathrm{~mm}(0.2 \mathrm{in}$.). However, the individual fractures that make up en échelon fracture sets are generally not throughgoing.

- Steeply dipping en échelon fracture zones, parallel fracture zones, and silicified brittle faults show consistent strikes to the NE and on average dip NW.

- Gently dipping to subhorizontal fractures in the gneissic rocks have an average strike and dip of N. $43^{\circ} \mathrm{E} ., 09^{\circ} \mathrm{SE}$.

The ground-water flow in the overburden is affected by the cap, barrier wall, and bedrock surface topography. Relatively small overburden horizontal head gradients (about $5 \mathrm{ft}$ across the site), and small overburden head fluctuations (about $0.5 \mathrm{ft}$ ) near the river, indicate that there is a poor hydraulic connection to the underlying bedrock and that there is relatively little ground-water flow in the overburden in the capped area. Although head fluctuations in the overburden are small, discharge through the drainage pipe in the retaining wall is variable indicating that there is some ground-water flow into the capped area. The overburden beneath the cap may receive inflow through or beneath the barrier wall, or by flow through vertical fractures in the underlying bedrock and beneath the barrier wall.

The bedrock aquifer near the river is well connected to the river and head gradients in the bedrock across the site are large (more than $10 \mathrm{ft}$ ). Water movement between the river and the bedrock aquifer is greatest during periods of river stage fluctuations. A bulk horizontal hydraulic conductivity of the bedrock was estimated, from stage and well water-level responses, to be about 0.2 to $20 \mathrm{ft} / \mathrm{d}$. Individual fractures or fracture zones likely have hydraulic conductivities much greater than the bulk rock and affect the higher hydraulic conductivity estimates. Ground water may move readily through near horizontal, or shallow to moderately dipping fractures along chlorite schist lenses or through near horizontal fractures at the pegmatite contacts near the river. The near-horizontal features may serve as conduits to the bulk of the site for ground water in steeply dipping fractures in gneiss. The horizontal, or gently dipping, fractures are discontinuous, therefore, the effective hydraulic conductivity across the site is likely to be closer to the low range of the estimated values $(0.2$ $\mathrm{ft} / \mathrm{d}$ ).

The geology and hydrology at the cell-house site represent a highly complex hydrogeologic environment in terms of ground-water flow and mercury transport. Because mercury is present in the dissolved, elemental and amalgamated form at the site, the effect of ground-water flow on mercury occurrence and transport will vary according to the form of the mercury. In addition, re-suspension and deposition of mercury from turbulent flows in the Androscoggin River may also affect the presence of elemental mercury along bedrock outcrops adjacent to the river. 


\section{Acknowledgments}

The authors wish to thank Fred McGarry, John Cotton, and Margaret Bastien of the New Hampshire Department of Environmental Services, and Vincent DelloRusso, James Soukup, Kathleen Soukup, Joseph Souney, and Joseph Schmidl of Weston Solutions, Inc., for their technical assistance, assistance with field activities, and collaboration. Special thanks go to Gregory Walsh, U.S. Geological Survey, for additional technical assistance and review. The authors also appreciate the assistance of the employees of the BerlinGorham Operations of Fraser Paper Inc., including Tammie Lavoie, Dennis Pednault, and David Bolstridge for their logistical support, sharing of data, and site access. Appreciation also is expressed to the employees of Great Lakes Hydro for safe access to the river channel below the Saw Mill Dam, and for providing stage records.

\section{References}

Ayotte, J.D., Mack, T.M., and Johnston, C.M., 1999, Geophysical surveys of Country Pond and adjacent wetland, and implications for contaminant-plume monitoring, Kingston, New Hampshire: U.S. Geological Survey Open-File Report 99-51, 16 p.

Barlow, P.M. and Moench, A.F., 1998, Analytical solutions and computer programs for hydraulic interaction of streamaquifer systems: U.S. Geological Survey Open-File Report 98-415A, 85 p.

Barton, C.C., Larsen, Eric, Page, W.R., and Howard, T.M., 1993, Characterizing fractured rock for fluid-flow, geomechanical, and paleostress modeling: Methods and preliminary results from Yucca Mountain, Nevada: U.S. Geological Survey Open-File Report 93-269.

Beres, Milan, Jr., and Haeni, F.P., 1991, Application of ground-penetrating-radar methods in hydrogeologic studies: Ground Water, v. 29, no. 3, p. 375-386.

Billings, M.P., 1972, Structural Geology (3d): Englewood Cliffs, N.J., Prentice Hall, Inc., 606 p.

Billings, M.P., and Billings, K.F., 1975, Geology of the Gorham Quadrangle, New Hampshire-Maine, Bulletin No. 6,: Concord, N.H., New Hampshire Department of Resources and Economic Development, 120 p., scale 1:62,500.

Brayton, M.J., and Harte, P.T., 2001, Results of a monitoring program of continuous water levels, specific conductance, and water temperature at the OK Tool Facility of the Savage Municipal Well Superfund Site, Milford, New Hampshire: U.S. Geological Survey Open-File Report 01-338, 50 p.
Degnan, J.R., Moore, R.B., and Mack, T.J., 2001, Geophysical investigations of well fields to characterize fractured bedrock aquifers in southern New Hampshire: U.S. Geological Survey Water-Resources Investigations Report 01-4183, $54 \mathrm{p}$.

Degnan, J.R., Clark, S.F., Jr., and Harte, P.T., 2003, Integration of geophysics, geologic mapping, and water-level monitoring to characterize the hydrology of a fractured bedrock site in Berlin, New Hampshire, in Symposium on the application of geophysics to engineering and environmental problems, Colorado Springs, Colo., February 22-26, 2004, Abstract: U.S. Environmental Protection Agency, ENVO5, p. 759-769.

Delvin, J.F., 2003, A spreadsheet method of estimating best-fit hydraulic gradients using head data from multiple wells: Ground Water, v. 41, no. 3., p. 316-320.

Ferguson, E.W., Clark, S.F., Jr., Marcoux, G.J., Short, H.A., and Moore, R.B., 1999, Lineament map of area 11, of the New Hampshire bedrock aquifer assessment, northeastern New Hampshire: U.S. Geological Survey Open-File Report 99-65, scale 1:48,000, 1 pl.

Hardcastle, K.C., 1995, Photolineament factor: A new computer-aided method for remotely sensing the degree to which bedrock is fractured: Photogrammetric Engineering and Remote Sensing, v. 61, no. 6, p. 739-747.

Johnson, C.D., Dunstan, A., Mack, T.J., and Lane, J.W., 1999, Borehole-geophysical characterization of a fractured-bedrock aquifer, Rye, New Hampshire: U.S. Geological Survey Open-File Report 99-558, p. 61.

Keyes, W.S., 1990, Borehole geophysics applied to groundwater investigations: Techniques of Water-Resource Investigations of the United States Geological Survey, chap. E2, $150 \mathrm{p}$.

Loke, M.H., 1999, Electrical imaging surveys for environmental and engineering studies, A practical guide to 2-D and 3-D surveys, Penang, Malaysia, accessed December 5, 1999 at URL http://www.geoelectrical.com/, 68 p.

Loke, M.H., and Lane, J.W., 2002, The use of constraints in $2 \mathrm{D}$ and $3 \mathrm{D}$ resistivity modeling, in the 8th Environmental and Engineering Geophysical Society European Section meeting, Aveiro, Portugal, September, 8-12, 2002: 4 p.

Lyons, J.B., Bothner, W.A., Moench, R.H., and Thompson, J.B., Jr., 1997, Bedrock geologic map of New Hampshire: U.S. Geological Survey State Geologic Map, 2 sheets, scale 1:250,000 and 1:500,000.

Mabee, S.B., Hardcastle, K.C., and Wise, D.U., 1994, A method of collecting and analyzing lineaments for regionalscale fractured-bedrock aquifer studies: Ground Water, v. 32, no. 6, p. 884-894. 
McDonald, H.R., 1950, How to estimate flow from pipes: Engineering News-Record, August 31, 1950, p. 48.

Moench, R.H., Boone, G.M., Bothner, W.A., Boudette, E.L., Hatch Jr., N.L., Hussey II, A.M., and Marvinney, R.G., 1995, Geologic map of the Sherbrooke-Lewiston area, Maine, New Hampshire, and Vermont, United States and Quebec, Canada: U.S. Geological Survey Miscellaneous Investigation Series Map I-1898-D, scale 1:250,000.

Moore, R.B., Schwarz, G.E., Clark, S.F., Jr., Walsh, G.J., and Degnan, J.R., 2002, Factors related to well yield in the fractured bedrock aquifer of New Hampshire: U.S. Geological Survey Professional Paper 1660, 51 p., 2 pls.

National Oceanic and Atmospheric Administration, 2003, daily precipitation data, accessed September 25, 2003, at URL http://www.erh.noaa.gov

Olimpio, J.R., and Mullaney, J.R., 1997, Geohydrology and water quality of stratified-drift aquifers in the Upper Connecticut and Androscoggin River Basins, northern New Hampshire: U.S. Geological Survey Water-Resources Investigations Report 96-4318, 172 p., 8 pls.

Powers, C.J., Singha, Kamini, and Haeni, F.P., 1999, Integration of surface geophysical methods for fracture detection in bedrock at Mirror Lake, New Hampshire, in Toxic Substances Hydrology Program Meeting, Charleston, S.C., March 8-12, 1999, Proceedings: U.S. Geological Survey, p. $757-768$.

Salvini, Francesco, 2002, The Structural Data Integrated System Analyzer software (DAISY 3.41b): Rome, Italy, Universita degli Studi "Roma Tre," Dipartimento di Scienze Geologiche.

Salvini, F., Billi, A., and Wise, D.U., 1999, Strike-slip fault propagation cleavage in carbonate rocks: the Mattinata Fault Zone, Southern Apennines, Italy: Journal of Structural Geology, v. 21, p. 1731-1749.

Shapiro, A.M., 2002, Characterizing fractured rock for water supply: From the well field to the watershed, in National Ground Water Association, Fractured-Rock Aquifers 2002, Denver, Colo., March 13-15, 2002, Proceedings: Denver, Colo., National Ground Water Association, p. 6-9.
Shapiro, A.M., and Hsieh, P.A., 2001, Aquifer testing in fractured rock: Conceptual similarities in aquifer heterogeneity from varied geologic settings: EOS Transcript American Geophysical Union, v. 87, no. 47, Fall Meeting Supplement, Abstract.

Spencer, E.W. and Kozak, S.J., 1976, Determination of regional fracture patterns in pre-Cambrian rocks-A comparison of techniques, in Hodgson, R.A., Gay, S.P., and Benjamins, J.Y., eds., Proceedings of the First International Conference on the New Basement Tectonics: Utah Geological Association, Publication \#5, p. 409-415.

Tiedeman, C.R., Goode, D.J., Hseih, P.A., 1997, Numerical simulation of ground water flow through glacial deposits and crystalline bedrock in the Mirror Lake Area, Grafton County, New Hampshire: U.S. Geological Survey Professional Paper 1572, $50 \mathrm{p}$.

Tighe and Bond, Inc., 2001, Site investigations, Pulp and Paper of America, Cell House Property, Berlin, New Hampshire: Westfield, Mass.

Thompson, J.B., Jr., Robinson, Peter, Clifford, T.N., and Trask, N.J., Jr., 1968, Nappes and Gneiss Domes in westcentral New England, in Zen., E., and White, W.S., (eds.), Studies of Appalachian Geology: Northern and Maritime: New York, John Wiley \& Sons, p. 203-218.

Walsh, G.J., and Clark, S.F., Jr., 2000, Contrasting methods of fracture trend characterization in crystalline metamorphic and igneous rocks of the Windham Quadrangle, New Hampshire: Northeastern Geology and Environmental Sciences, v. 22 , no. 2 , p. $109-120$.

Wise, D.U., Funiciello, R., Parotto, M., and Salvini, F., 1985, Topographic lineament swarms: Clues to their origin from domain analysis of Italy: Geological Society of America Bulletin, v. 96, p. 952-967.

Zohdy, A.A.R., Eaton, G.P., and Mabey, D.R., 1974, Application of surface geophysics to ground-water investigations: U.S. Geological Survey Techniques of Water-Resources Investigations, book 2, chap. D1, 86 p. 



\section{Appendix 1 - Core Logs}


Core log from borehole at bedrock well B-4A (location unknown, not on map)

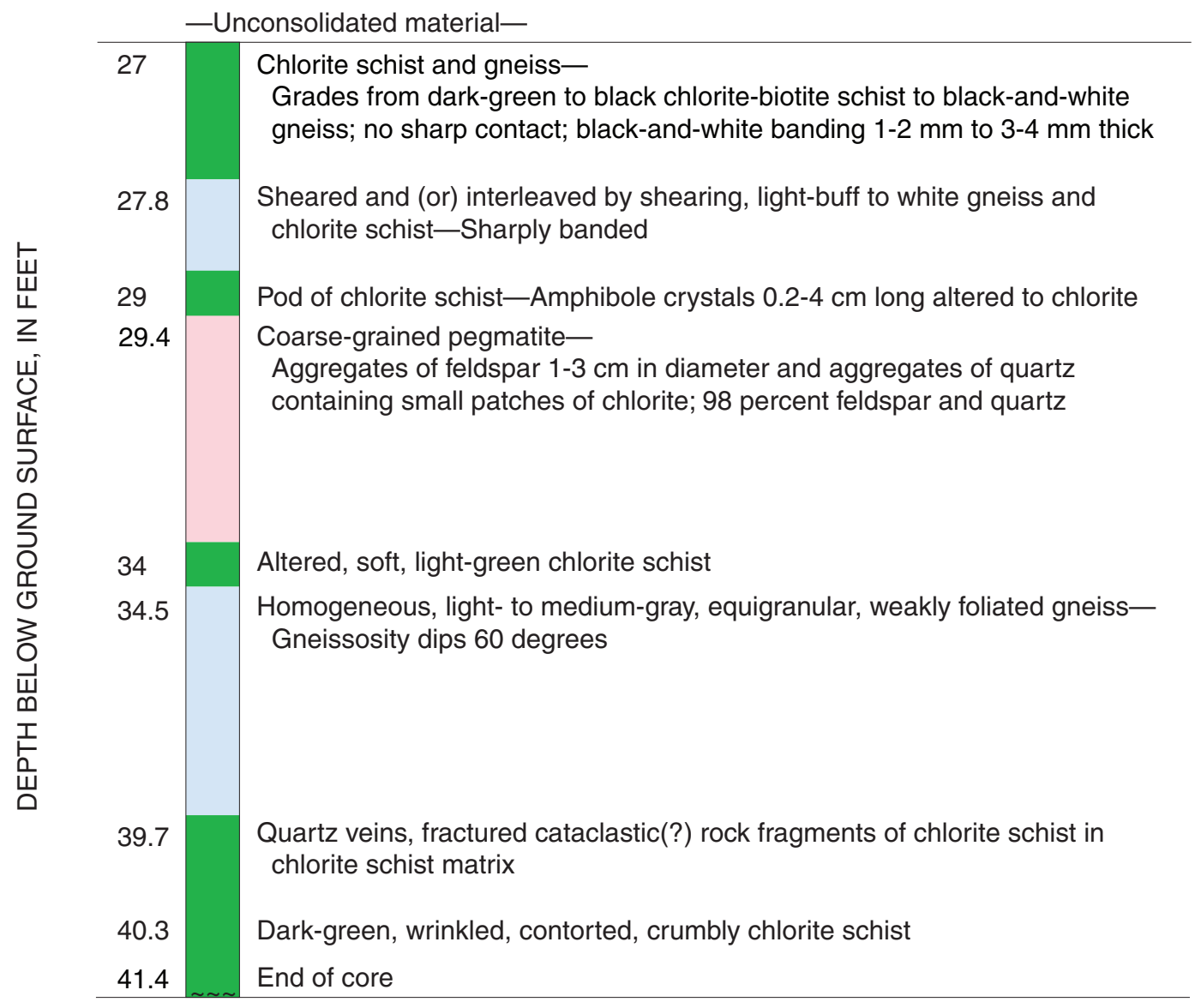

Not to scale

Figure 1-1. Core log from borehole at bedrock well B-4A, cell-house site, Berlin, N.H. 
Core log from borehole at bedrock well MW-4AR (possibly P 4-A based on depth)

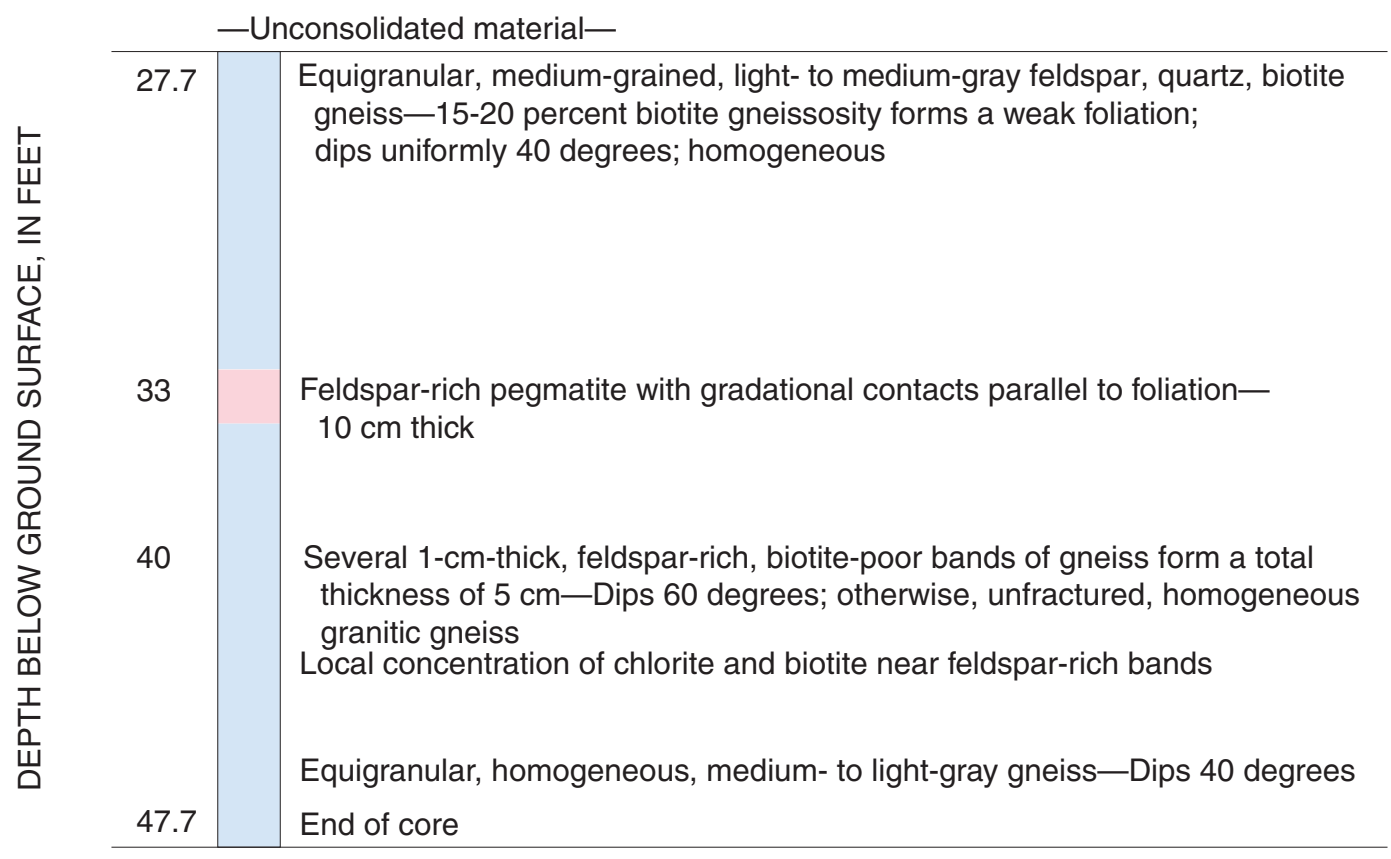

Not to scale

Figure 1-2. Core log from borehole at bedrock well MW-4AR, cell-house site, Berlin, N.H. 


\section{Core log from borehole at bedrock well MW-7}

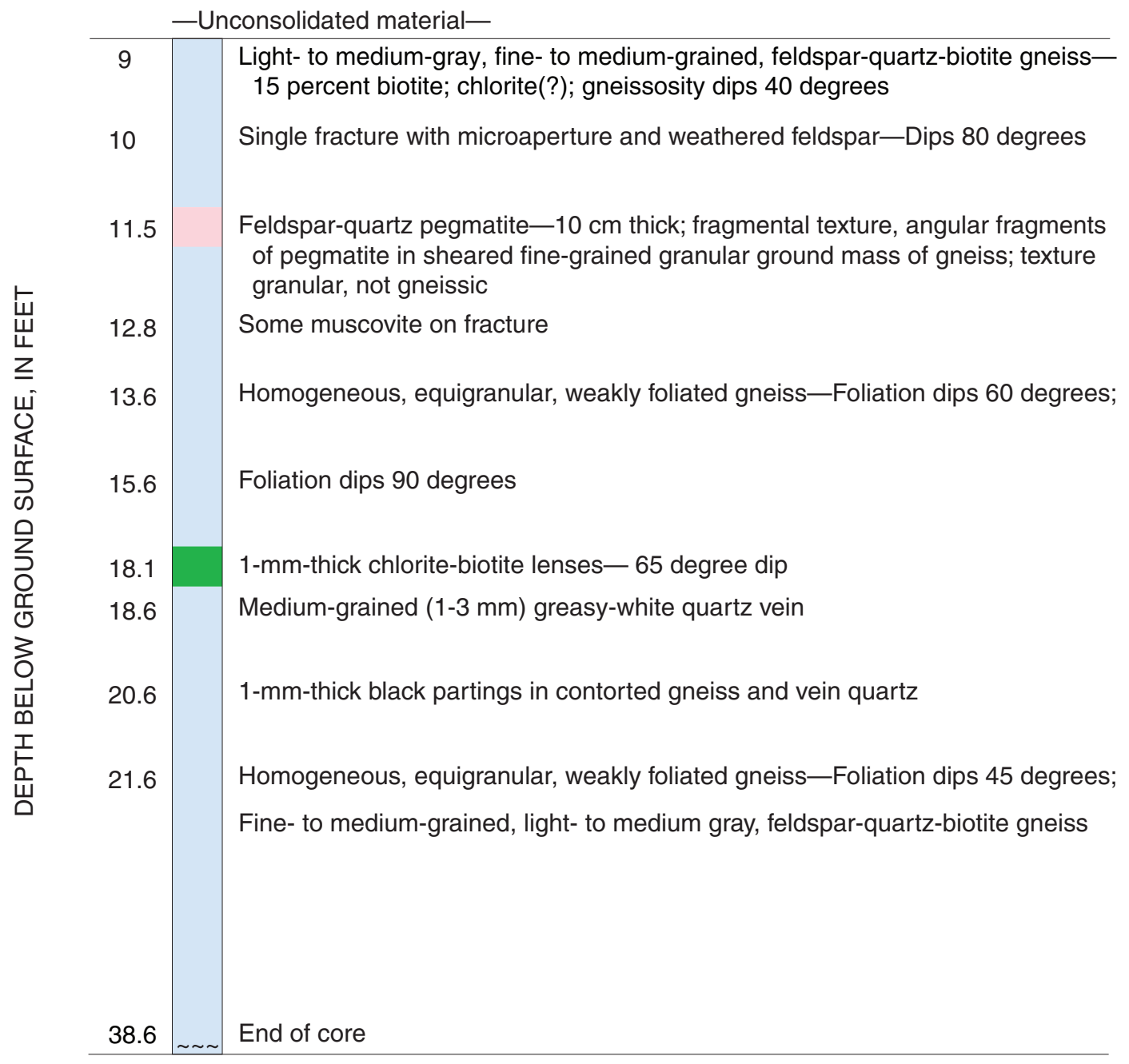

Not to scale

Figure 1-3. Core log from borehole at bedrock well MW-7, cell-house site, Berlin, N.H. (See figure 2 for location of well and plate 1 for structure and distribution of rock types.) 


\section{Core log from borehole at bedrock well MW-8}

Generally very homogeneous, coarse-grained, medium-gray feldspar-quartz-biotite gneiss -Unconsolidated material-

\begin{tabular}{|c|c|}
\hline 11 & Coarse-grained $(0.5 \mathrm{~cm}$ in diameter) white feldspar-quartz pegmatite \\
\hline 11.5 & $\begin{array}{l}\text { Dark-green, vuggy, porous, weathered chlorite schist-Differential weathering } \\
\text { leaves irregular, open framework along foliation; dips } 60 \text { degrees }\end{array}$ \\
\hline 11.8 & Fine-grained, light-gray feldspar-quartz-biotite gneiss-15 percent biotite \\
\hline 12.4 & Chlorite-biotite schist-85 percent chlorite and biotite; 15 percent feldspar \\
\hline 12.7 & $\begin{array}{l}\text { Fine-grained, light-gray feldspar-quartz-biotite gneiss- } \\
15 \text { percent biotite; gneissosity dips } 40 \text { degrees }\end{array}$ \\
\hline 13.8 & $\begin{array}{l}\text { Fracture dips } 60 \text { degrees-Cuts gneissosity; 3-4 mm-diameter muscovite flakes } \\
\text { on fracture surface } \\
\text { Core parallels vertical contact of pink and white feldspar pegmatite and fine- } \\
\text { to medium-grained gray gneiss-Contact is irregular, melted; gneissosity } \\
\text { cut by pegmatitie; metallic, silver-gray, hard, irregular xenoliths 1-5 mm in } \\
\text { diameter along contact }\end{array}$ \\
\hline 15.8 & $\begin{array}{l}\text { Fine-grained, light-gray feldspar-quartz-biotite gneiss_-15 percent biotite; } \\
\text { very weakly foliated } \\
\text { Some pink feldspar grains in gneiss }\end{array}$ \\
\hline 19.8 & $\begin{array}{l}\text { Core parallels vertical contact of pink and white feldspar pegmatite and fine- } \\
\text { to medium-grained gray gneiss-Contact is irregular, melted; gneissosity cut } \\
\text { by pegmatite; very weak foliation in gneiss; foliation dips } 85 \text { degrees }\end{array}$ \\
\hline 21.8 & Mix of pegmatite and gneiss \\
\hline 23.3 & Feldspar-quartz pegmatite \\
\hline 25.3 & Mix of pegmatite and gneiss \\
\hline 27.9 & Snow-white, fine-grained quartzite(?) or feldspar-quartz gneiss without biotite \\
\hline \multirow[t]{2}{*}{29} & $\begin{array}{l}\text { Fine-grained, light-gray feldspar-quartz-biotite gneiss- } \\
15 \text { percent biotite; very weak foliation; faint pink core in some feldspar } \\
\text { aggregates; open, weathered fracture with micro-aperture; fracture cuts } \\
\text { gneissosity and dips } 80 \text { degrees }\end{array}$ \\
\hline & $\begin{array}{l}\text { Pegmatite-Pink alteration of feldspar where fracture above cuts pegmatite; } \\
15 \text { percent steel-gray metallic xenoliths } 0.4-1 \mathrm{~cm} \text { in diameter are in pegmatite }\end{array}$ \\
\hline 30 & $\begin{array}{l}\text { Very fine grained, snow-white pegmatite-Intrusive fingers cut and assimilate } \\
\text { gneiss }\end{array}$ \\
\hline 30.7 & $\begin{array}{l}\text { Fine-grained, light-gray feldspar-quartz-biotite gneiss- } \\
15 \text { percent biotite; very weakly foliated }\end{array}$ \\
\hline 34.2 & $5 \mathrm{~cm}$ of snow-white, fine-grained pegmatite-Metallic xenoliths in gneiss \\
\hline \multirow[t]{2}{*}{35.5} & $\begin{array}{l}\text { Weathered fracture parallels gneissosity-Dips } 45 \text { degrees; } \\
\text { second fracture terminates on first fracture at } 90 \text { degrees }\end{array}$ \\
\hline & $\begin{array}{l}\text { Fine-grained, light-gray feldspar-quartz-biotite gneiss- } \\
15 \text { percent biotite; very weakly foliated; unfractured }\end{array}$ \\
\hline 43.5 & End of core \\
\hline
\end{tabular}

Not to scale

Figure 1-4. Core log from borehole at bedrock well MW-8, cell-house site, Berlin, N.H. (See figure 2 for location of well and plate 1 for structure and distribution of rock types.) 


\section{Core log from borehole at bedrock well MW-9}

Generally very homogeneous, coarse-grained, medium-gray feldspar-quartz-biotite gneiss

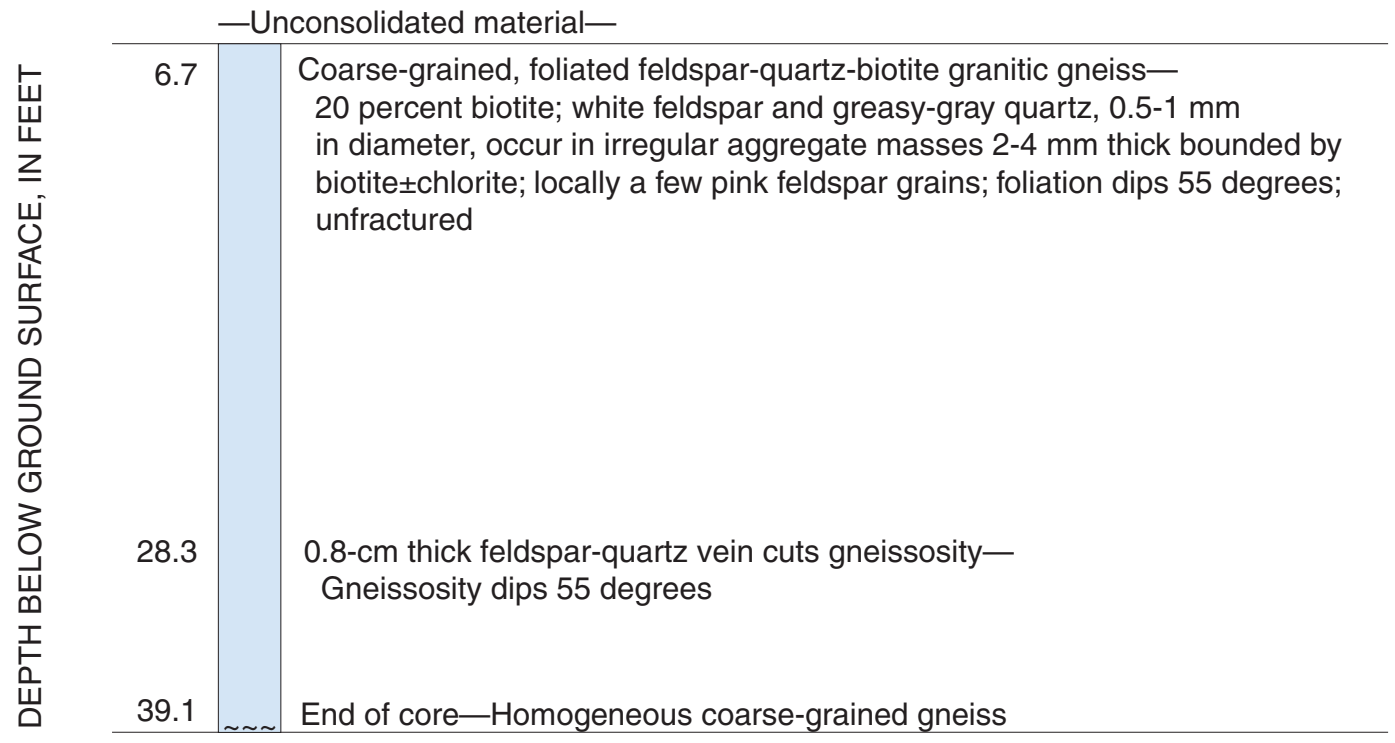

Not to scale

Figure 1-5. Core log from borehole at bedrock well MW-9, cell-house site, Berlin, N.H. (See figure 2 for location of well and plate 1 for structure and distribution of rock types.) 


\section{Core log from borehole at bedrock well MW-10A}

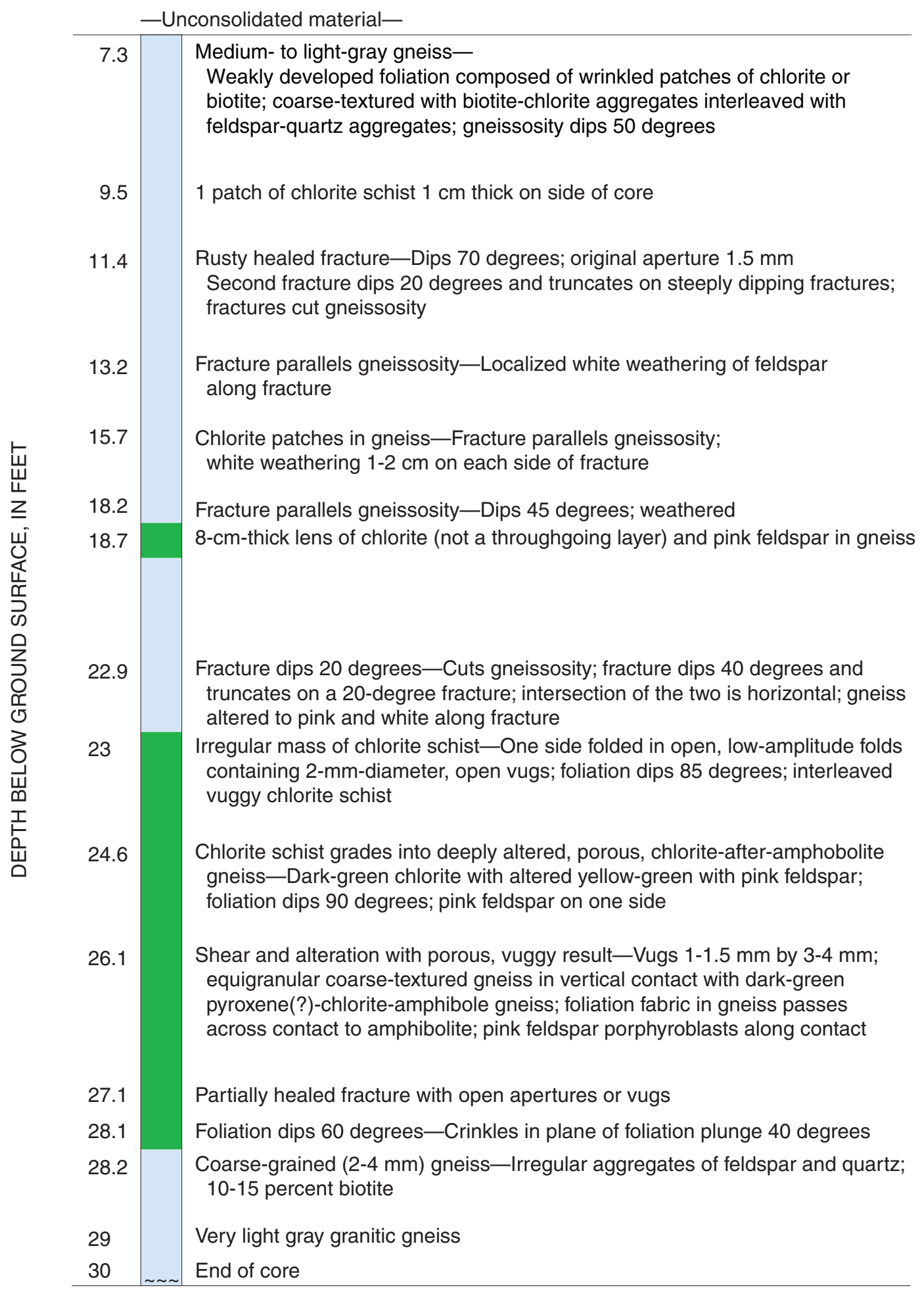

Not to scale

Figure 1-6. Core log from borehole at bedrock well MW-10A, cell-house site, Berlin, N.H. (See figure 2 for location of well and plate 1 for structure and distribution of rock types.) 
Prepared by the New Hampshire-Vermont District Publications Unit-Debra H. Foster, Anita Cotton, and Ann Marie Squillacci

For more information concerning the research in this report, contact: Brian Mrazik, District Chief

U.S. Geological Survey

361 Commerce Way

Pembroke, NH 03275

or visit our Web site at:

http://nh.water.usgs.gov 
